\title{
Arbeidsmarktmonitor Metalektro Editie 2009
}

Ben Kriechel

Andries de Grip

Gerla van Breugel

Johan Coenen

ROA-R-2009/2 


\section{Colofon}

(C) Researchcentrum voor Onderwijs en Arbeidsmarkt (ROA). Niets uit deze uitgave mag op enige manier worden verveelvoudigd zonder voorafgaande schriftelijke toestemming van de directeur van het ROA.

\section{Researchcentrum voor Onderwijs en Arbeidsmarkt}

Faculteit der Economische Wetenschappen en Bedrijfskunde

Maastricht University

\section{Vormgeving}

ROA secretariaat, Maastricht

\section{Verkoop}

Researchcentrum voor Onderwijs en Arbeidsmarkt email: secretary-roa@maastrichtuniversity.nl

website: www.roa.unimaas.nl

ISBN: 978-90-532I-476-3

mei 2009 


\section{Inhoud}

\section{Voorwoord}

Management Summary vii

1 Dynamiek in de Metalektro 1

1.1 Van hoog tot laag - Metalektro in het teken van de crisis 1

1.2 Maatregelen tijdens de crisis 2

1.3 Werkgelegenheidsontwikkeling 4

$\begin{array}{ll}1.4 \text { Innovatie - technisch en organisatorisch } & 6\end{array}$

2 Arbeidsmarktontwikkelingen in 2008

2.1 De personeelsinstroom in 2008 9

$\begin{array}{ll}2.2 \text { De personeelsuitstroom in } 2008 & 11\end{array}$

2.3 Werkgelegenheidsontwikkelingen in $2008 \quad 14$

2.4 Flexibel inlenen 16

3 Vacatures en werving van personeel 19

$\begin{array}{ll}3.1 \text { Vrijwillig vertrek van personeel } & 19\end{array}$

3.2 Vacatures 23

$\begin{array}{lll}3.3 & \text { Effectieve wervingskanalen } & 30\end{array}$

3.4 Wervingsproblemen en bijbehorende maatregelen 32

4 Loopbaanmanagement $\quad 41$

4.1 Waarom loopbaanmanagement in de Metalektro? $\quad 41$

4.2 Vaststellen van huidig en gewenst competentieniveau 42

4.3 Ontwikkeling competenties door scholing 47

4.4 Ontwikkeling competenties door interne mobiliteit 54

4.5 Loopbaanmanagementinstrumenten in verleden en toekomst 56

5 Sociale innovatie $\quad 59$

5.1 Sociale innovatie: wat en waarom?

5.2 Organisatie en management 60

5.3 Benutting en ontwikkeling van menselijk kapitaal 65

$\begin{array}{lll}5.4 \text { Externe samenwerking } & 71\end{array}$

5.5 Knelpunten bij de uitvoering van sociale innovatie 72 
6 Vergrijzing en active aging beleid $\quad 75$

6.1 Uitstroom door vergrijzing en vervangingsproblemen $\quad 75$

6.2 Aanpak vervangingsproblemen ontstaan door vergrijzing 78

6.3 Active aging 80

7 De Metalektro in de toekomst $\quad 85$

7.1 Arbeidsmarktontwikkelingen in de Metalektro op de korte termijn: 2009-2010 85

7.2 Werving op de middellange termijn: 2009-2013 88

7.3 Veranderingen in technische functies op de middellange

7.4 HRM beleid op de middellange termijn: 2009-2013 91

8 Agenda voor de toekomst $\quad 95$

8.1 Ontwikkelingen en trends 95

$\begin{array}{ll}8.2 \text { Agenda voor de Toekomst } & 100\end{array}$ 


\section{Voorwoord}

In 2002 is in opdracht van de Stichting $\mathrm{A}+\mathrm{O}$ een start gemaakt met de opzet van een Arbeidsmarktmonitor voor de Nederlandse Metalektro. Deze monitor geeft inzicht in de actuele ontwikkelingen op de arbeidsmarkt en de toekomstige ontwikkelingen op personeels- en arbeidsmarktgebied in de metalektrosector. Deze rapportage vormt de afsluiting van de zevende jaarcyclus van de Arbeidsmarktmonitor. Het rapport combineert de belangrijkste resultaten van het voor de monitor opgezette Werkgeverspanel Metalektro en de Quickscans met informatie uit diverse andere bronnen. Om dieper te kunnen ingaan op de achtergronden van de ontwikkelingen, problemen en knelpunten waarmee de bedrijven in de Metalektro te maken hebben, is een aantal gesprekken georganiseerd. De gesprekken zijn verwerkt tot tekstkaders waarin de meningen van bedrijven over een aantal onderwerpen kernachtig samengevat worden. Deze kaders zijn door het hele rapport verspreid en gaan in op de wijze waarop bedrijven bepaalde ontwikkelingen en knelpunten in de praktijk ervaren en hoe ze daarmee omgaan. Ze zijn een waardevolle aanvulling op de informatie die in de hoofdtekst wordt gepresenteerd.

In 2008 zijn de metalektrobedrijven twee keer benaderd om mee te doen aan het werkgeverspanel. In iedere meting van dit panel beantwoordt een representatieve groep bedrijven uit de Metalektro via Internet een lijst met vragen over de in- en uitstroom van personeel in de zes maanden voorafgaand aan de meting en het aantal openstaande vacatures. Naast deze standaardvragen wordt er in iedere meting ingegaan op bepaalde thema's zoals werving en selectie, de inzetbaarheid en de doorstroom van personeel, sociale en technologische innovatie en organisatorische vernieuwingen, en de competenties en scholing van het technisch personeel. Ook in 2008 is er weer veel aandacht besteed aan het verder verbeteren van de vraagstellingen in het werkgeverspanel. Door nieuwe vragen te introduceren en bestaande vragen verder aan te scherpen is geprobeerd om de informatie die het werkgeverspanel oplevert nog beter af te stemmen op de behoefte van de bedrijven.

Bij de start van het panel in 2002 zijn alle Metalektrobedrijven, die aangesloten zijn bij de werkgeversorganisatie FME-CWM en vallen onder de CAO Metalektro, benaderd om deel te nemen aan het Werkgeverspanel. Vanaf 2006 is dit panel aangevuld met een Quickscan die twee keer per jaar gehouden wordt. Daarin wordt de bedrijven gevraagd hun mening te geven over een vijftal stellingen. 
Om een representatief beeld te kunnen geven van de ontwikkelingen in de Nederlandse Metalektro wordt de informatie die de deelnemende bedrijven aanleveren gewogen naar bedrijfsomvang, bedrijfssector en regio. Om vervolgens uitspraken te kunnen doen over bijvoorbeeld het totale aantal vacatures dat in de Metalektro openstaat, is het aantal vacatures dat bij de deelnemende bedrijven openstaat opgehoogd. Deze ophoging van vacaturecijfers komt overeen met de procedure die het CBS volgt in hun landelijke vacature-enquête. Deze aanpak heeft als voordeel dat we een goed beeld kunnen geven van de ontwikkeling van het totale aantal vacatures dat er bij de bedrijven in de Metalektro openstaat. Ook de cijfers over de in- en uitstroom van werknemers in de Metalektro zijn opgehoogd tot in de tijd vergelijkbare totaalcijfers voor de hele sector.

$\mathrm{Na}$ iedere meting van het Werkgeverspanel Metalektro worden de uitkomsten gepubliceerd in een door de Stichting A+O uitgegeven nieuwsbrief. In deze nieuwsbrief wordt niet alleen gerapporteerd over de actuele arbeidsmarktsituatie (vacatures, instroom en uitstroom, werkgelegenheidskrimp) en de arbeidsmarktverwachtingen voor de komende periode, maar komen ook andere trends en ontwikkelingen aan de orde. Daarnaast gaan we in iedere nieuwsbrief in een redactioneel commentaar in op de dynamiek in de Metalektro en de situatie op de arbeidsmarkt. Door de ontwikkelingen in de Metalektro in een wat breder perspectief te plaatsen wordt meer inzicht gegeven in wat de gevolgen van bepaalde trends en problemen zijn en wat dit voor het beleid kan betekenen. Ieder deelnemend bedrijf ontvangt ook nog een bedrijfsfoto. Dit benchmarkinstrument vergelijkt de positie van het eigen bedrijf met het algemene beeld van de bedrijfstak.

De inbreng en de betrokkenheid van de deelnemende bedrijven blijft cruciaal om de Arbeidsmarktmonitor Metalektro verder te ontwikkelen en draagt er toe bij dat de monitor een instrument is vóór en dóór de bedrijven. Daarom willen we de bedrijven die mee hebben gedaan aan de metingen van het Werkgeverspanel Metalektro en de Quickscans van harte bedanken. Daarnaast bedanken we de bedrijven die bereid waren om deel te nemen aan de verdiepende gesprekken. De uitvoering van de Arbeidsmarktmonitor Metalektro en het samenstellen van deze jaarrapportage staat onder leiding van een regiecommissie. Deze commissie bestaat uit de volgende leden: Henry de Groot (Stichting A+O), Rien Smit (FME-CWM), Hilde ter Doest (FNV Bondgenoten, tot eind 2008), Astrid Ophof (FNV Bondgenoten, sinds 2009) en Marije Oudejans (CentERdata). De auteurs van dit rapport willen de leden van deze regiecommissie hartelijk bedanken voor hun constructieve feedback en de wijze waarop ze het onderzoek begeleid hebben. Het veldwerk voor het Werkgeverspanel Metalektro is uitgevoerd door Marije Oudejans van CentERdata. Sander Dijksman (ROA) werkte mee aan de statistische analyses in dit rapport. 


\section{Management Summary}

De ontwikkelingen in de Metalektro werden het afgelopen jaar overheerst door de crisis die in de tweede helft van 2008 begon. Deze crisis dreigt een aantal structurele ontwikkelingen in de sector aan het oog te onttrekken zoals de lage instroom van schoolverlaters en de groeiende uitstroom als gevolg van pensionering. Enerzijds wordt de korte termijn bij bedrijven beïnvloed door de crisis, anderzijds vragen de structurele arbeidsmarktontwikkelingen in de Metalektro om een lange termijn aanpak door de bedrijven. In deze management summary komt dit tot uiting in een tweeluik waarin het eerste deel ingaat op de effecten van de crisis voor de bedrijven in de Metalektro, terwijl in het tweede deel de meer structurele ontwikkelingen en hun effecten op diezelfde metalektrobedrijven aan bod komen.

\section{Metalektro in het teken van de crisis}

In de tweede helft van 2008 manifesteerde de crisis zich in de Metalektro door een vaak sterk teruglopende vraag bij steeds meer bedrijven. Een derde van de bedrijven produceert volgens de CBS Conjunctuurenquête minder door een teruglopende vraag. In reactie hierop ontdoen de bedrijven zich van hun flexibele schil door afscheid te nemen van hun uitzendkrachten en gedetacheerden. Ook zijn veel tijdelijke contracten niet verlengd. In de tweede meting van de Arbeidsmarktmonitor Metalektro blijkt dat $46 \%$ van de bedrijven minder gebruik makt van uitzendkrachten, terwijl $31 \%$ tijdelijke contracten niet verlengt. Het aantal uitzendkrachten in de Metalektro is hierdoor in de tweede helft van 2008 nagenoeg gehalveerd ten opzichte van de eerste helft van 2008.

De bedrijven stellen echter veel in het werk om hun vaste personeel te behouden. Leegloopuren worden bijvoorbeeld besteed aan scholing zowel via formele cursussen als informele trainingen op de werkplek. Deze informele training houdt bijvoorbeeld in dat werknemers meedraaien op andere afdelingen om zo hun inzetbaarheid te vergroten en nieuwe vaardigheden te leren. Daarnaast haalt bijna een kwart van de bedrijven eerder uitbesteed werk terug.

Ondanks de verminderde productie is de werkgelegenheid voor het vaste personeel nog slechts licht gedaald. Bovendien zijn er, ondanks de crisis, nog steeds bedrijven die moeilijk vervulbare vacatures hebben. Eind 2008 stond meer dan de helft van deze 
vacatures al 6 maanden of langer open. Bedrijven zijn veelal nog steeds op zoek naar technici met een $\mathrm{MBO}$ of $\mathrm{HBO}$ werk- en denkniveau.

De crisis blijkt weinig invloed te hebben op toekomstige innovaties. Het percentage bedrijven dat product- of procesinnovaties over de komende vijf jaar verwacht daalt slechts licht. Dit onderstreept het belang van innovaties voor de branche. Zelfs in tijden van crisis blijven bedrijven innoveren.

\section{Structurele Ontwikkelingen}

\section{Vacatures}

Hoewel de crisis ervoor gezorgd heeft dat ruim de helft van de vacatures is komen te vervallen, hebben bedrijven in de Metalektro in januari 2009 nog steeds vacatures. Het gaat dan meestal om vacatures voor uitvoerende, leidinggevende en ondersteunende technici. Zorgelijk is hierbij dat een steeds groter deel van deze vacatures lang open staat. Zo zoeken bedrijven voor $38 \%$ van de vacatures al 6 maanden tot een jaar naar een passende kandidaat en bij nog eens I $8 \%$ van de vacatures zijn bedrijven al meer dan een jaar zoekende naar een geschikte kandidaat. Ondanks de recente terugval in het aantal vacatures verwachten veel bedrijven voor de komende 5 jaar problemen bij de vervanging van hun personeel dat met pensioen gaat. Ondanks de crisis blijft een goed wervingsbeleid van belang, zelfs op de korte termijn. Bedrijven betrekken graag externe partijen zoals uitzendbureaus en wervingsbureaus in hun wervingsbeleid vanwege de effectiviteit van deze bureaus in het aanbrengen van nieuw personeel. Daarnaast is het internet als wervingskanaal in opkomst in de Metalektro.

\section{Arbeidsmarkt}

Zowel de instroom als uitstroom van vast personeel bij de metalektrobedrijven blijven op een hoog niveau. Een deel van het personeel stroomt op eigen initiatief uit en gaat aan de slag bij een andere werkgever omdat deze een betere baan biedt qua salaris en inhoud. Ook zijn 'vertrekkers' vaker op zoek naar een baan met meer loopbaanperspectief en mogelijkheden om werk en privé beter met elkaar te kunnen combineren. Bedrijven proberen dit vrijwillig vertrek steeds meer te voorkomen door inhoudelijk interessant werk aan te bieden met voldoende mogelijkheden voor verdere opleiding en ontwikkeling in combinatie met concurrerende arbeidsvoorwaarden. De verwachtingen voor de komende twee jaar wijzen uit dat de al eerder ingezette trend van minder werkgelegenheid voor LBO-ers ten gunste van een groeiende werkgelegenheid voor $\mathrm{MBO}$-ers en $\mathrm{HBO}$-ers, versterkt wordt door de crisis. 


\section{Innovaties}

Innovaties zijn van structureel belang voor de bedrijven in de Metalektro. Eén op de vijf bedrijven heeft innovatie dan ook ingebed in haar bedrijfsstrategie. Bovendien streeft $40 \%$ van de metalektrobedrijven er naar om binnen vijf jaar een innovatiegerichte strategie te hebben ontwikkeld. Het percentage bedrijven dat technologische innovaties (product- en procesinnovaties) plant, blijft ook in 2008 op een hoog niveau, zeker als het gaat om de innovatieplannen voor de komende vijf jaar. Een kwart van de bedrijven wil zich in de komende jaren richten op het ontwikkelen van productgerelateerde diensten. Technologische innovaties kunnen slechts optimaal renderen als de menselijke inbreng de technologische innovaties ondersteunt. Oftewel, geen technologische innovatie zonder sociale innovatie. De metalektrobedrijven blijken wat betreft sociale innovaties op het terrein van organisatie en management vooral bezig te zijn met horizontale vernieuwingen van de organisatie. Zo probeert men steeds vaker in teamverband te werken, projectmatig te werken of om taken over afdelingen heen te integreren. Deze organisatorische veranderingen hebben ook invloed op de inhoud van de technische functies. Veel bedrijven verwachten dan ook dat hun technici de komende vijf jaar meer verantwoordelijkheid zullen gaan dragen en meer allround zullen worden. De meerderheid van de bedrijven verwacht dat organisatorische veranderingen pas na vijf jaar effect zullen hebben. Echter, verschillende bedrijven geven aan dat het invoeren van zelfsturende teams en taakintegratie over de afdelingen al tot een hogere arbeidproductiviteit en kwalitatief betere producten heeft geleid of dat ze dit effect binnen een jaar verwachten.

POFI+

De komende vijf jaar zal de inhoud van veel functies in de Metalektro veranderen. Bedrijven verwachten met name dat de gedragsmatige competenties belangrijker worden. De gedragsmatige competenties zijn samengevat in de POFI+ agenda en bestaan uit probleemoplossend vermogen, omgaan met veranderingen, omgaan met klanten, flexibiliteit en initiatief. Ook verwacht men dat medewerkers meer verantwoordelijkheden zullen krijgen en een breder takenpakket. Wanneer bedrijven schoolverlaters uit het $\mathrm{MBO}$ en $\mathrm{HBO}$ aannemen, zullen zij onder andere moeten worden getraind in communicatie en problemen oplossen. De schoolverlaters geven namelijk zelf aan dat zij op deze competenties nog tekort schieten.

\section{Training}

Het samenspel van technologische en sociale innovatie in de Metalektro zorgt er voor dat de competenties van het personeel regelmatig moeten worden aangepast en uitgebreid. Zo worden medewerkers voorbereid op toekomstige functieveranderingen. Bedrijven trainen hun personeel momenteel voornamelijk op het gebied van vaktechnische vaardigheden, communicatie en leiding geven. De trainingsdeelname onder werknemers in de Metalektro stijgt, maar de kosten per deelnemer nemen af. Ook in 
de toekomst blijft het belang van vaktechnische en communicatieve trainingen hoog. Daarnaast zullen er vaker cursussen gericht op het oplossen van problemen en het plannen en organiseren van activiteiten worden gevolgd.

De leidinggevenden en afdelingen $\mathrm{P} \& \mathrm{O}$ spelen een belangrijke rol bij het stimuleren van de trainingsdeelname van hun personeel. Zij zijn in staat om het benodigde budget in tijd en geld vrij te maken zodat het personeel cursussen kan volgen. Gebrek aan tijd en geld is namelijk één van de belangrijkste belemmeringen waardoor personeel minder training volgt dan gewenst. Bovendien hebben leidinggevenden en P\&O-ers het meeste inzicht in het huidige en gewenste competentieniveau van de medewerkers. Deze kennis verwerven zij onder andere door het regelmatig houden van functioneringsgesprekken en beoordelingsgesprekken. Meer dan $80 \%$ van de bedrijven gebruikt deze HRM instrumenten als basis van hun personeelsbeleid.

\section{Vervangingsproblematiek}

In de Metalektro zullen bedrijven regelmatig zoeken naar nieuw personeel. Het zij omdat een werknemer vrijwillig vertrokken is, hetzij omdat een oudere werknemer met pensioen gaat. Bij het vervangen van de toekomstige pensioenuitstroom verwacht maar liefst driekwart van de bedrijven problemen. Het is daarom van belang om het oudere personeel zo lang mogelijk productief aan het werk te houden. De aandacht voor maatregelen om dit te bereiken neemt echter af. Vrijwel alle maatregelen gericht op het langer aan het werk houden van personeel van 45 jaar en ouder worden door minder bedrijven toegepast dan in voorgaande jaren.

De vervangingsproblemen concentreren zich op de uitvoerende, leidinggevende en ondersteunende technische functies. Eén van de manieren om deze problemen aan te pakken is door vrijgevallen functies intern te vervullen. Dit resulteert in een interne doorstroom van het personeel. In 60\% van de bedrijven stromen technici intern door; in vier op de vijf gevallen betreft dit een interne promotie. Daarnaast wil men in de toekomst medewerkers breed inzetten om zo de vervangingsproblemen op te lossen. Ook kan een betere afstemming tussen werk en privé er voor zorgen dat enerzijds de oudere medewerkers langer aan het werk blijven en anderzijds het bedrijf attractiever wordt voor jongere werknemers. 


\section{Dynamiek in de Metalektro}

De dynamiek op de arbeidsmarkt staat sinds enkele maanden in het teken van de 'crisis'. In dit hoofdstuk worden enkele belangrijke ontwikkelingen van de werkgelegenheidsontwikkeling in de Metalektro in kaart gebracht. Paragraaf I.I schetst de conjuncturele ontwikkeling van de Metalektro in de afgelopen jaren. Daarna wordt in paragraaf I.2 ingegaan op de maatregelen die bedrijven nemen als reactie op de crisis. Paragraaf 1.3 geeft vervolgens de werkgelegenheidsontwikkeling in de afgelopen jaren weer. Tot slot wordt in paragraaf I.4 ingegaan op de innovatie-ontwikkeling.

\subsection{Van hoog tot laag - Metalektro in het teken van de crisis}

$\mathrm{Na}$ enkele jaren van redelijke tot zeer goede ontwikkelingen op de afzetmarkt voor de Metalektro staat de sector al maanden in het teken van de crisis. De recessie, die uit deze financiële crisis is voortgekomen, veroorzaakt een behoorlijke teruggang van de vraag. Vooral bedrijven die producten aan de hard getroffen automotive sector leveren, worden met een enorme achteruitgang in hun afzet en orderportefeuille geconfronteerd. Het is dan ook vanzelfsprekend dat in de recente Conjunctuurtest van het CBS als grootste productiebelemmering "onvoldoende vraag" aangegeven wordt. Figuur I.I geeft het verloop van twee voor de Metalektrosector belangrijke belemmeringen, 'onvoldoende vraag' en 'personeelstekort', van 1994 tot 2009 weer. De stippellijn geeft het percentage bedrijven weer die geen enkele productiebelemmering ondervinden, de lichtblauwe lijn geeft de ontwikkeling van het percentage bedrijven met onvoldoende vraag en de zwarte lijn de ontwikkeling van het percentage bedrijven met een personeelstekort.

De snelheid waarmee de huidige crisis is opgekomen, is goed te zien in de stijging van het aantal bedrijven dat aangeeft dat ze met "onvoldoende vraag" kampen. Deze factor is binnen zes maanden gestegen van 5\% in juli 2008 naar $32 \%$ in januari 2009 . Daarmee is deze factor al op het niveau van begin 1994. Dit terwijl de meeste bedrijven nog een verdere vraaguitval verwachten. Het verloop van het percentage bedrijven zonder productiebelemmeringen weerspiegelt dit beeld. In een extreem korte periode valt dit percentage van $74 \%$ terug naar $41 \%$. Een enorme daling die in de gehele observatieperiode van 1994 tot 2009 niet eerder is voorgekomen. 


\section{Figuur 1.1}

Productiebelemmeringen in de Metalektro, 1994-2009 (\% bedrijven)

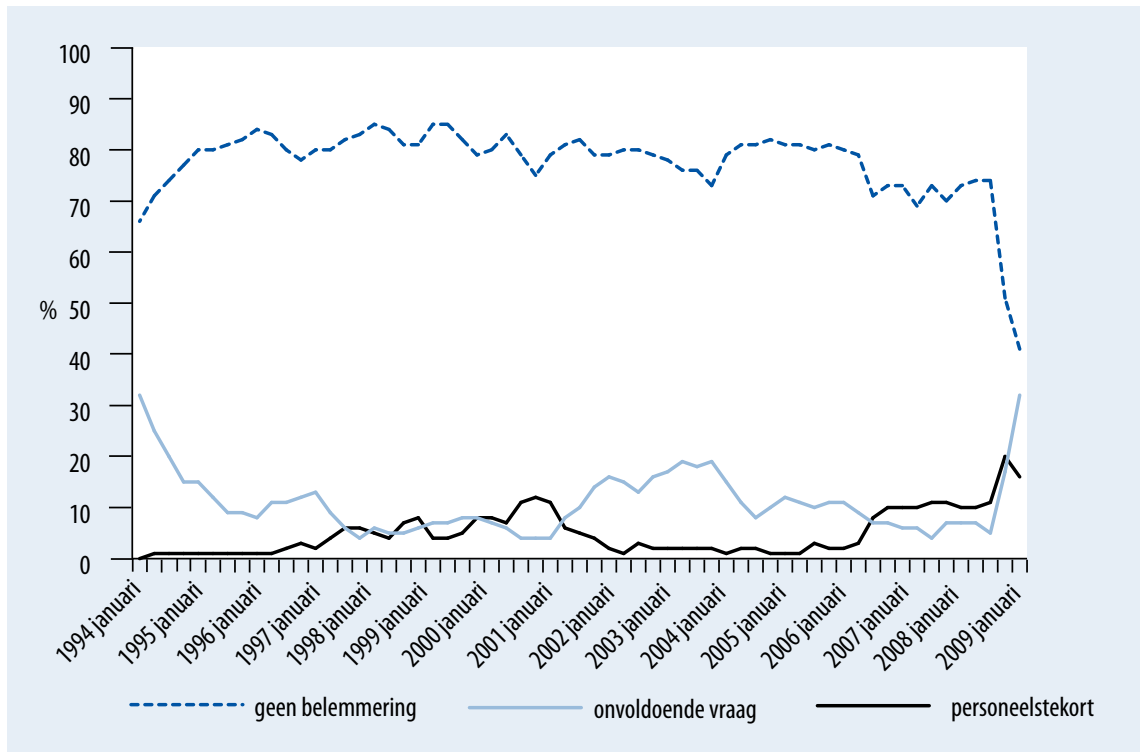

Bron: CBS Conjunctuurtest Industrie (SBI: 27)

Ook is het duidelijk dat de crisis niet alle personeelstekorten in de sector oplost. Het percentage bedrijven dat productiebelemmeringen door personeelstekorten ondervindt, stijgt namelijk nog tot oktober 2008, om daarna slechts langzaam af te nemen. Het niveau in januari 2009 is echter hoger dan in de voorgaande jaren. Eenzelfde trend is ook zichtbaar in deze Arbeidsmarktmonitor Metalektro: de cijfers met betrekking tot het aantrekken van nieuw personeel geven aan dat een deel van de metalektrobedrijven in januari 2009 nog steeds problemen heeft om vacatures in te vullen (zie hoofdstuk 3).

\subsection{Maatregelen tijdens de crisis}

Hoe reageren bedrijven op de teruglopende vraag, en de onzekerheid over de duur van de crisis? Hoe wordt er omgegaan met de spagaat tussen de vraaguitval enerzijds en de toekomstige personeelstekorten anderzijds? Door de vraaguitval is een deel van het personeel immers nu overbodig, maar de kans is groot dat ditzelfde personeel op de middellange termijn weer hard nodig is om in ieder geval de hoge pensioenuitstroom en de verminderde instroom van schoolverlaters op te vangen. 
Figuur 1.2

Effecten crisis voor ondernemingen in Nederland (\% bedrijven)

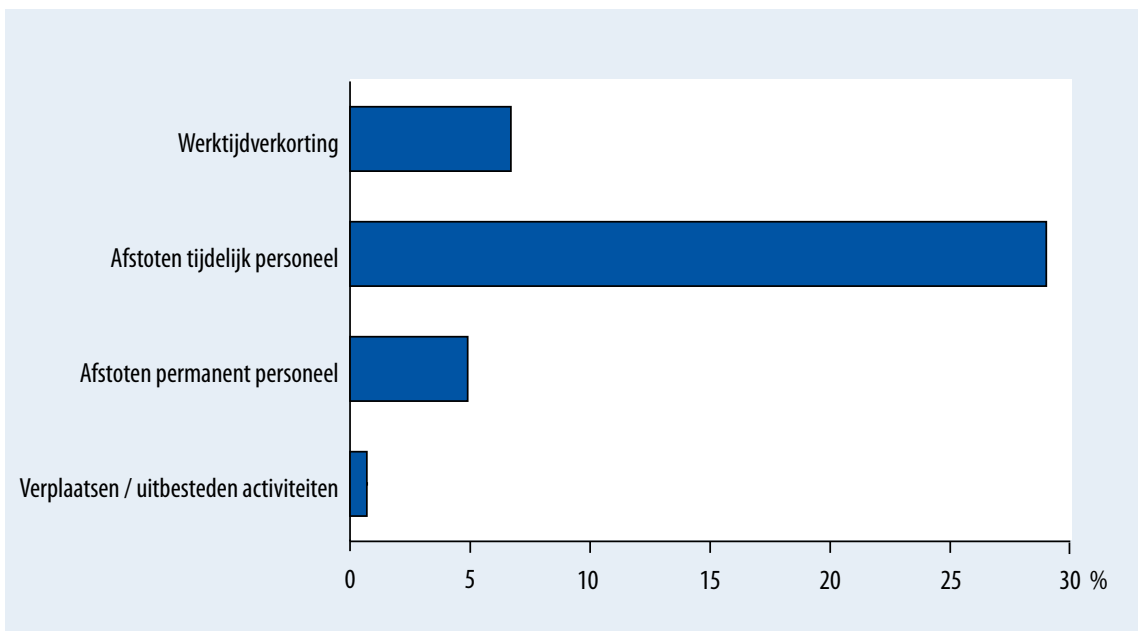

Bron: CBS Conjunctuurtest Industrie, Metaal(producten), machine- en vervoermiddelenindustrie, januari 2009

Figuur I.2 geeft de effecten van de crisis weer voor de ondernemingen in de sector Metaal(producten), machine- en vervoermiddelenindustrie (CBS indeling). Uit deze CBS cijfers blijkt dat vooral het afstoten van personeel en werktijdvermindering veel gebruikte maatregelen zijn. Dit correspondeert met uitkomsten van de Arbeidsmarktmonitor Metalektro (zie figuur I.3). Ook hieruit blijkt dat in veel bedrijven de 'flexibele schil' wordt afgestoten door afscheid te nemen van uitzendkrachten en tijdelijke contracten niet te verlengen. Slechts een beperkte groep bedrijven ontslaat hun permanente personeel als gevolg van de crisis. Het verplaatsen of uitbesteden van activiteiten om op die manier kosten te besparen komt nauwelijks voor. Uit de cijfers van de Arbeidsmarktmonitor Metalektro blijkt eerder het tegendeel. Zo is in figuur I. 3 te zien dat een aantal bedrijven eerder uitbesteed werk weer terughaalt om zo hun personeel van werk te voorzien. Zoals ook in hoofdstuk 5 besproken wordt, neemt het percentage bedrijven dat activiteiten uitbesteedt over de breedte af. 


\section{Figuur 1.3}

Maatregelen bedrijven ten gevolge van de crisis, 2008 (\% bedrijven)

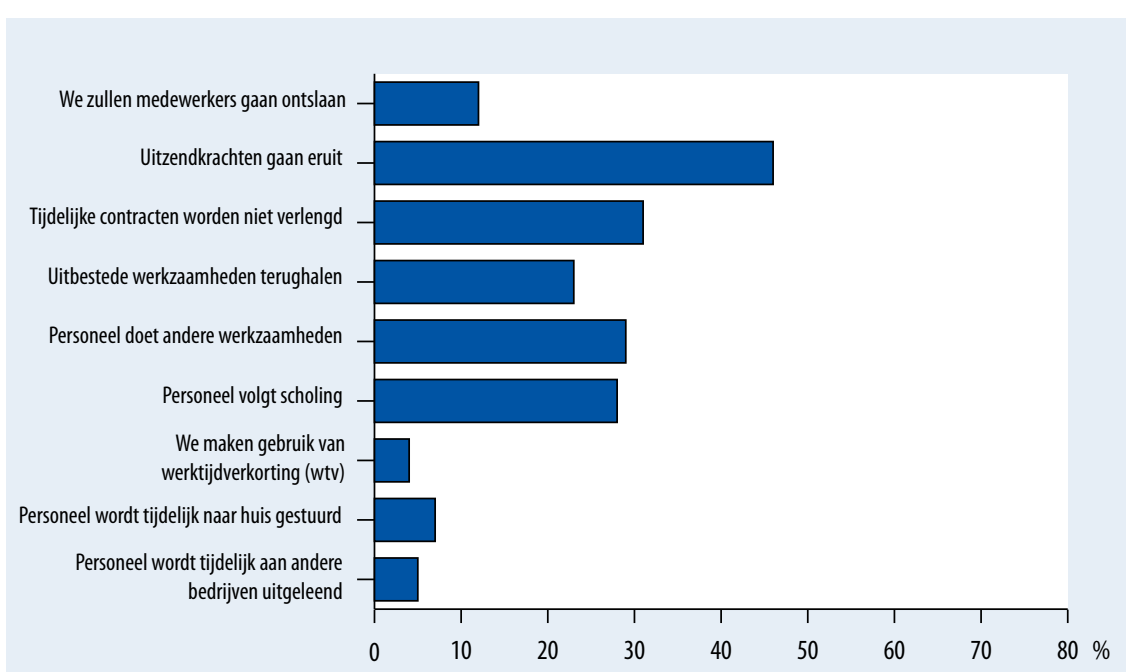

Bron: ROA / Werkgeverspanel Metalektro 2008

Naast het afstoten van het personeel en het verplaatsen van de productie zijn er natuurlijk nog andere mogelijkheden. Figuur I.3 geeft een gedetailleerd overzicht van maatregelen die metalektrobedrijven kunnen nemen. Het zittende personeel, dat bedrijven willen behouden, heeft door de crisis minder te doen. Ruim een kwart van de bedrijven geeft aan dat het personeel hierdoor scholing kan volgen en bijna een derde van de bedrijven geeft aan dat het personeel andere werkzaamheden uitvoert. Sommige bedrijven combineren ook werk en scholing door tijdens de crisis werknemers over verschillende functies te laten rouleren en zo ervaring op te laten doen. De verminderde bedrijvigheid schept nu mogelijkheden voor dergelijke ontwikkelactiviteiten.

\subsection{Werkgelegenheidsontwikkeling}

Sinds een aantal jaren daalt de werkgelegenheid in de Metalektro overigens al enigszins. Deze licht dalende trend zet ook in 2007 door. Figuur I.4 geeft de werkgelegenheidsontwikkeling ten opzichte van het basisjaar 1996 weer. De figuur is afkomstig van cijfers uit de Enquête Beroepsbevolking (EBB) van het CBS. Deze cijfers lopen echter enigszins achter op de actuele ontwikkelingen omdat de cijfers van 2008 nog niet bekend zijn. De effecten van de crisis zijn daarom in figuur I.4 niet te zien. 
Figuur 1.4

Ontwikkeling index van het aantal werkenden in de Metalektro (basisjaar: 1996), 1996-2007

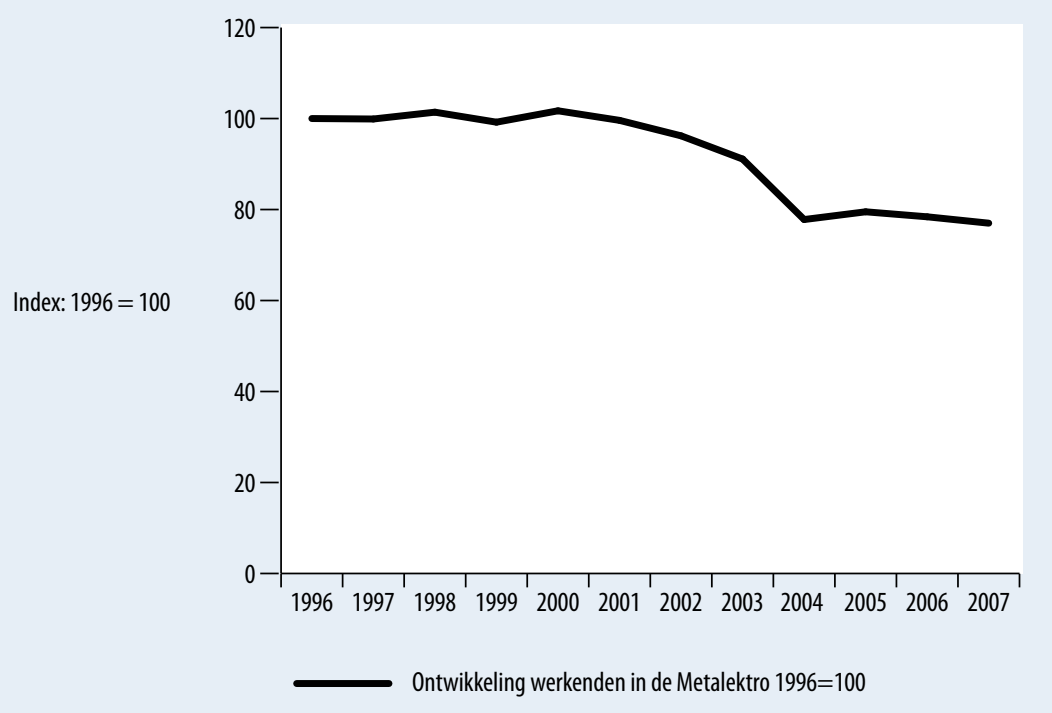

Bron: CBS Enquête Beroepsbevolking, 1996-2007

Meer actuele cijfers voor de Metalektro zijn te vinden in hoofdstuk 2 van dit rapport. Hieruit blijkt dat de personeelinstroom in de eerste helft van 2008 zeer hoog was en dat deze ook in de tweede helft van 2008 nog vrij hoog bleef. Ook de uitstroom is in beide periodes zeer hoog. Hierdoor neemt de werkgelegenheid in de eerste periode toe en in de tweede periode licht af. De grotere afname van de werkgelegenheid is eerder voor 2009 te verwachten, zeker als bedrijven toch besluiten om vast personeel te ontslaan. Dit is natuurlijk mede afhankelijk van het verdere verloop van de crisis.

Daarbij moet ook in het oog worden gehouden dat de Metalektro een sector is met een relatief oud personeelbestand. $2 \mathrm{I} \%$ van de werknemers is 50 jaar of ouder, terwijl $17 \%$ jonger is dan 30 jaar. Binnen de sector hebben basismetaalbedrijven het oudste personeelsbestand. Hier is slechts $\mathrm{I} 3 \%$ van de werknemers jonger dan 30 , en maar liefst $27 \% 50$ jaar of ouder. Traditioneel is de Metalektro een mannendomein: $87 \%$ van de werknemers is man. In de elektrotechniek werken relatief gezien nog de meeste vrouwen $(2 \mathrm{I} \%)$.

Van de werkenden in de Metalektro heeft bijna de helft (49\%) een opleiding op middelbaar niveau (MBO) gevolgd. Ongeveer een derde (30\%) is laag opgeleid (VMBO of lager), terwijl $22 \%$ hoger is opgeleid ( $\mathrm{HBO}$ en WO). 


\subsection{Innovatie - technisch en organisatorisch}

Technologische innovatie, dat wil zeggen product- en procesinnovaties, zijn voor de meeste metalektrobedrijven van levensbelang. De crisis heeft dan ook niet al te veel invloed op de verwachtingen over de nieuwe producten of productieprocessen, die op korte termijn (I jaar) of op middellange termijn ( 5 jaren) ingevoerd zullen worden. Wel neemt het percentage bedrijven dat op korte en middellange termijn nieuwe producten zal introduceren af. Een uitzondering hierop is de ontwikkeling van nieuwe diensten die zowel op de korte termijn als in de komende vijf jaar zal toenemen.

\section{Figuur 1.5}

Bedrijven met product- of procesinnovatie, 2009 en 2009-2013, (\% bedrijven)

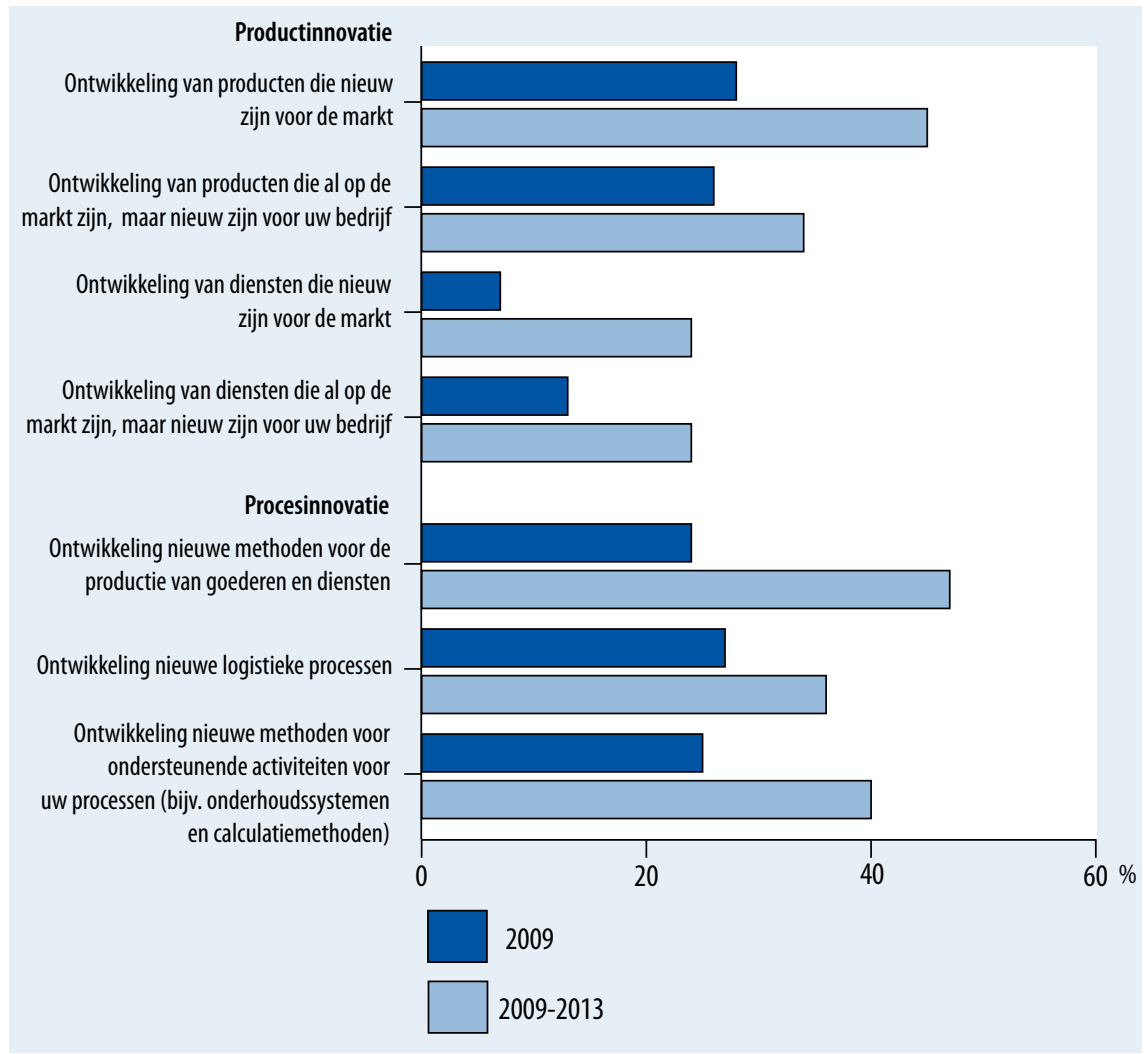

Bron: ROA / Werkgeverspanel Metalektro 2008

Figuur I.5 geeft de actuele verwachtingen voor 2009 en de periode 2009-2013 weer. $45 \%$ van de bedrijven geeft aan binnen vijf jaar een voor de markt nieuw product te ontwikkelen. Een derde van de bedrijven zal in de komende vijf jaar een voor het bedrijf nieuw product op de markt brengen. Maar vooral interessant is de ontwikke- 
ling van diensten die nieuw zijn voor de markt. Uit de cijfers valt af te lezen dat veel bedrijven zich hierop richten: terwijl maar $7 \%$ van de bedrijven dit op korte termijn wil realiseren, verwacht bijna een kwart van de bedrijven hier in de komende vijf jaar mee te komen.

Naast de productinnovaties zijn de procesinnovaties van groot belang. $47 \%$ van de bedrijven verwacht in de komende vijf jaar een nieuwe of veranderde productiemethode toe te passen. Bij procesinnovatie zijn ook de verbeteringen van logistieke processen en ondersteunende processen van belang. 36\% van de bedrijven verwacht een verandering op logistiek vlak en $40 \%$ op ondersteunend gebied. Deze cijfers komen nagenoeg overeen met de verwachtingen die bedrijven een jaar eerder, dus ruim voor de crisis hadden.

Nauw verbonden met technologische innovaties zijn ook de sociale innovaties (zie hoofdstuk 5). Veranderende producten en processen vereisen immers vaak ook een andere inzet van werknemers. Deze veranderingen zijn noodzakelijk om tot de nieuwe producten of procesinnovaties te komen. Het percentage bedrijven dat in de komende jaren één of meerdere vormen van sociale innovatie verwacht door te voeren blijft, ondanks de crisis, onveranderd hoog. Zowel op de korte als op de middellange termijn worden veelvuldig veranderingen gepland (zie hoofdstuk 5). Bedrijven proberen door sociale innovatie productiever te worden en kwalitatief betere producten te leveren. Zowel voor technische als sociale innovaties geldt nadrukkelijk dat zij gedragen en uitgevoerd moeten worden door het personeel. Bovendien moet het personeel op deze innovaties worden voorbereid. Dit geldt des te meer omdat procesinnovaties veelal gepaard gaan met veranderingen in de organisatie van het werk en de competenties waarover medewerkers moeten beschikken om optimaal te kunnen functioneren in hun nieuwe werksituatie. 



\section{Arbeidsmarktontwikkelingen in 2008}

In dit hoofdstuk wordt een beeld geschetst van de arbeidsmarktontwikkelingen in de Metalektro in 2008. In paragraaf 2.I komen de ontwikkelingen in de personeelsinstroom in de Metalektro aan bod, vervolgens wordt in paragraaf 2.2 de personeelsuitstroom van het afgelopen jaar onder de loep genomen, waarna in paragraaf 2.3 wordt ingegaan op de algemene werkgelegenheidsontwikkelingen in de sector. Paragraaf 2.3 geeft ook een beeld van bedrijven met krimpende werkgelegenheid en welke gevolgen dit heeft. Ten slotte wordt in paragraaf 2.4 getoond in welke mate metalektrobedrijven gebruik maken van het flexibel inlenen van personeel.

\subsection{De personeelsinstroom ${ }^{1}$ in 2008}

Hoe heeft de personeelsinstroom zich ontwikkeld in 2008? Wie van de bedrijven in de Metalektro heeft nog nieuwe medewerkers aangenomen? En hoeveel werknemers gingen er in 2008 in totaal aan de slag? In figuur 2.I geven de staven het totaal aantal werknemers weer dat in 2008 in dienst is genomen. Deze aantallen zijn af te lezen op de linkeras. In aanvulling hierop wordt in de lijngrafiek op de rechteras het percentage bedrijven dat in 2008 nieuwe werknemers in dienst nam weergegeven.

In totaal stroomden er bij de metalektrobedrijven in de eerste helft van 20086.900 werknemers in. Dit is ruim meer dan de 5.900 werknemers die in de eerste helft van 2007 instroomden en veel meer dan de 3.700 werknemers in de tweede helft van 2007. Ruim driekwart van de bedrijven in de Metalektro nam in de eerste helft van 2008 uitvoerende technici in dienst. In totaal werden er 3.600 werknemers in deze categorie aangenomen. Ruim de helft van de bedrijven nam werknemers in dienst voor ondersteunende technische functies. Het ging hier in totaal om ruim I.300 werknemers. Vier op de tien bedrijven namen medewerkers voor ondersteunende niet-technische functies aan, in totaal ging het hier om ongeveer 950 medewerkers. Ongeveer een vijfde van de bedrijven nam technisch opgeleide verkopers of technische en niet-technische leidinggevenden aan.

I. De personeelsinstroom heeft alleen betrekking op nieuwe werknemers die door het bedrijf in dienst genomen zijn. Werknemers die op uitzend- of detacheringsbasis voor het bedrijf zijn komen werken worden hier dus niet meegeteld, maar komen aan bod in paragraaf 2.4 


\section{Figuur 2.1}

Totaal aantal aangenomen werknemers in de Metalektro (linkeras) en percentage bedrijven met nieuw aangenomen werknemers (rechteras), 2008

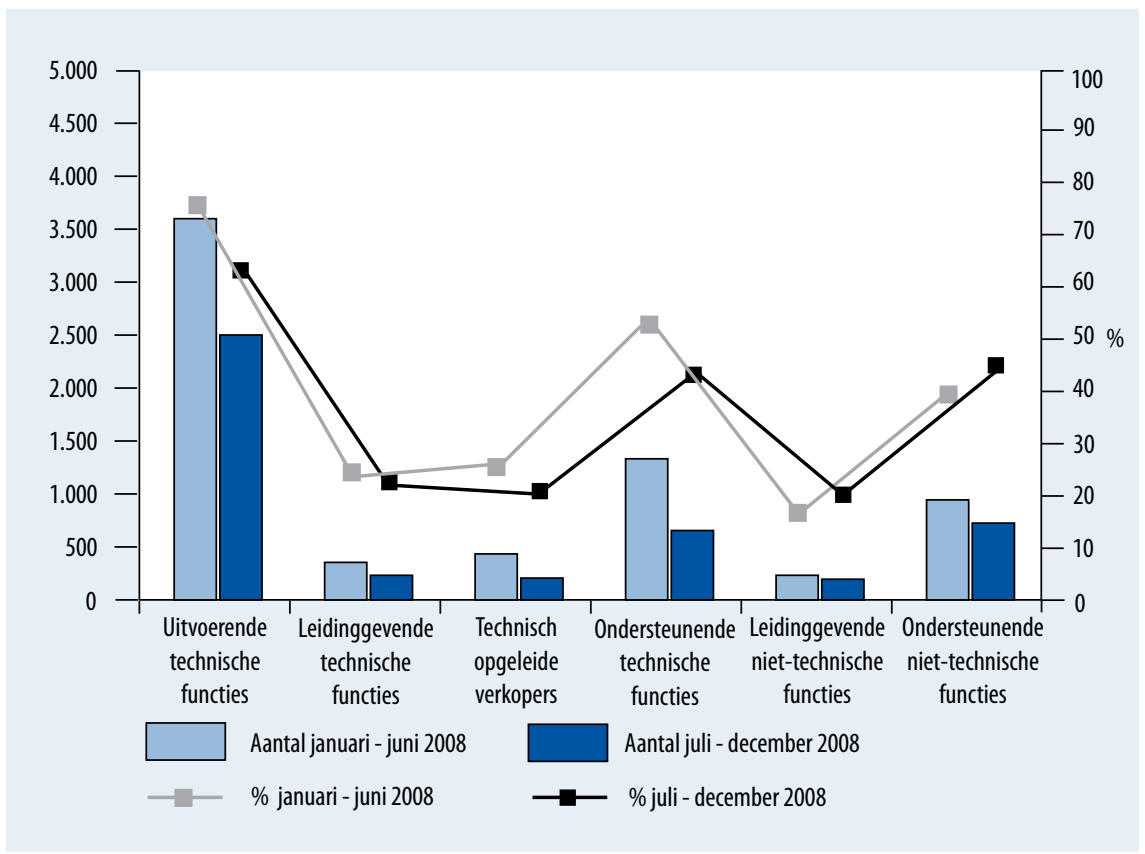

Bron: ROA / Werkgeverspanel Metalektro

In de tweede helft van het jaar is de personeelsinstroom binnen alle functiecategorieën in de Metalektro gedaald. Niet omdat er veel minder bedrijven in de Metalektro mensen in dienst namen, maar vooral omdat zij minder mensen aannamen. In totaal stroomden er tussen juli en december 2008 circa 4.500 werknemers in, veel minder dan in de eerste helft van het jaar. Dit wijst erop dat de bedrijven in de Metalektro een teruggang in de orderportefeuille verwachten als gevolg van de economische recessie. Ze nemen met het oog hierop aanzienlijk minder mensen in dienst. De instroom van uitvoerende technici daalde met ruim duizend mensen van 3.60o tot 2.500. Deze instroom kwam in de tweede helft van 2008 voor rekening van $69 \%$ van de bedrijven, tegenover $76 \%$ in de eerste helft van het jaar. Nog sterker was de afname in de instroom bij de ondersteunende technische functies en de technisch opgeleide verkopers; deze halveerde ten opzichte van de eerste helft van 2008 . Bovendien nam nu nog $43 \%$ van de bedrijven in de Metalektro ondersteunende technici in dienst, tegenover $53 \%$ in de eerste helft van 2008. Alleen de instroom van niet-technische leidinggevenden bleef min of meer constant rond de 200 in 2008 . Er was het afgelopen jaar de meeste dynamiek in de instroom en de uitstroom van technische medewerkers. In deze functies werken ook de meeste mensen. 
Figuur 2.2

Ontwikkeling instroom van nieuwe werknemers, 2002-2008

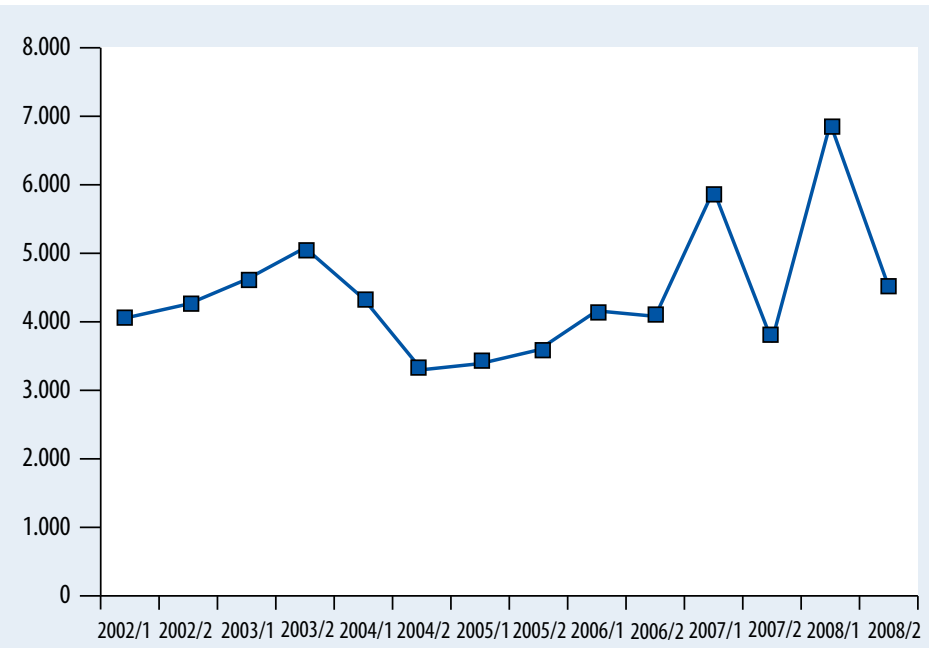

Noot: De cijfers van 2002 tot en met 2004 zijn berekend op basis van 3 metingen (2004) of 4 metingen (2002 en 2003) in plaats van op 2 metingen (sinds 2005).

Bron: ROA / Werkgeverspanel Metalektro

In figuur 2.2 wordt de ontwikkeling van de personeelsinstroom sinds het begin van de arbeidsmarktmonitor weergegeven. Van begin 2002 tot eind 2003 steeg de personeelsinstroom met I.OOO werknemers van ongeveer 4.IOO tot ongeveer 5.IOO nieuwe werknemers. Daarna volgde een sterke daling van de instroom. Mogelijk onder invloed van de recessie daalde het aantal nieuwe werknemers bij de bedrijven in de Metalektro tot 3.300 in de tweede helft van 2004. Vervolgens is de personeelsinstroom twee jaar lang weer gestegen tot ongeveer 4.IOO in de tweede helft van 2006. Vanaf 2007 zijn er echter grote verschillen in de personeelsinstroom tussen de eerste en de tweede meting van het jaar. $\mathrm{Na}$ de hoogste personeelinstroom in de geschiedenis van de arbeidsmarktmonitor in de eerste helft van 2008 (6.900) is dit aantal in de tweede helft van 2008 weer terug op een vrij gemiddeld niveau: 4.500 .

\subsection{De personeelsuitstroom ${ }^{2}$ in $\mathbf{2 0 0 8}$}

De sterk verslechterde toestand van de economie in de tweede helft van 2008 heeft ook gevolgen voor de Metalektro. Blijkt dat ook al uit de personeelsuitstroom in

2. De personeelsuitstroom heeft alleen betrekking op vertrokken werknemers die in dienst waren van het bedrijf. Het vertrek van werknemers die op uitzend- of detacheringsbasis in het bedrijf werkzaam waren, wordt hier dus niet meegeteld, maar komt aan bod in paragraaf 2.4. 
2008? Figuur 2.3 geeft op de linkeras per functiecategorie weer hoeveel werknemers er in totaal uitstroomden en op de rechteras het percentage bedrijven in de Metalektro met personeelsuitstroom.

\section{Figuur 2.3}

Totaal aantal vertrokken werknemers in de Metalektro (linkeras) en percentage bedrijven met vertrokken werknemers (rechteras), 2008

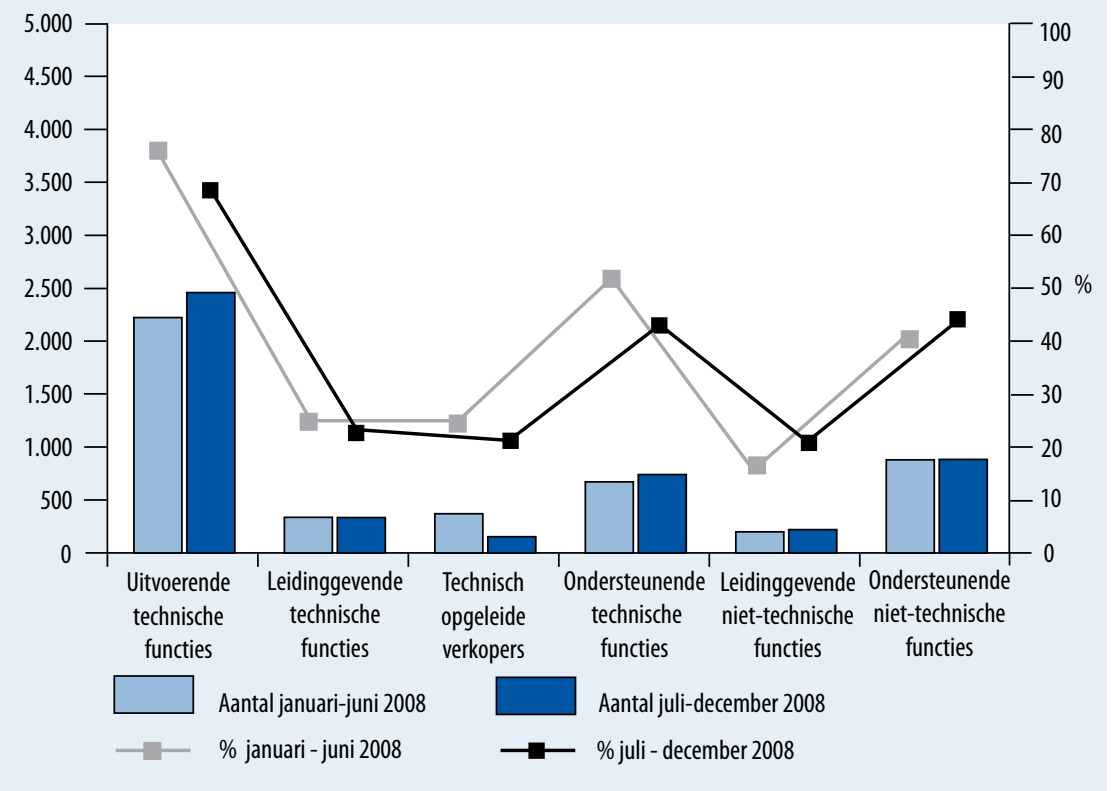

Bron: ROA / Werkgeverspanel Metalektro

In totaal vertrokken er in de eerste helft van 2008 bijna 4.700 werknemers bij hun bedrijf. Dit is zo'n 300 werknemers meer dan in de eerste helft van 2007 , en zelfs 2.000 werknemers meer dan in de tweede helft van 2007 .

Ongeveer driekwart van alle bedrijven had in de eerste helft van 2008 te maken met uitstroom van uitvoerende technici. Er vertrokken ongeveer 2.200 uitvoerende technici bij de bedrijven in de Metalektro. Bij een derde van de metalektrobedrijven vertrokken er werknemers uit ondersteunende technische en niet-technische functies. Uit deze functies vertrokken respectievelijk 670 en 880 werknemers. $20 \%$ van de bedrijven zagen leidinggevende technici vertrekken (340), terwijl in I2\% van de bedrijven bij elkaar 200 niet-technische leidinggevenden het bedrijf verlieten. Een kwart van de bedrijven had te maken met uitstroom van technisch opgeleide verkopers. Het gaat hier om ongeveer 370 werknemers. 
Figuur 2.4

Ontwikkeling personeelsuitstroom, 2002-2008

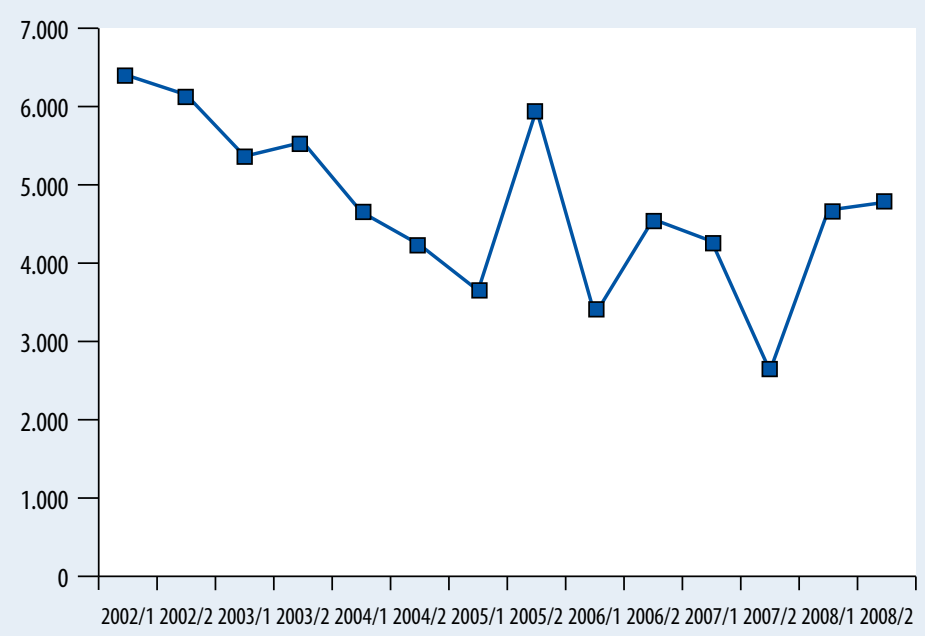

Noot: De cijfers van 2002 tot en met 2004 zijn berekend op basis van 3 metingen (2004) of 4 metingen (2002 en 2003) in plaats van op 2 metingen (sinds 2005).

Bron: ROA / Werkgeverspanel Metalektro

De totale personeelsuitstroom van het vaste personeel bedroeg in de tweede helft van 2008 bijna 4.800 werknemers. Dit is slechts een kleine toename ten opzichte van de eerste zes maanden van 2008. De verslechterde economische situatie lijkt dus nog niet te leiden tot een forse toename in de uitstroom. Wel is de personeelsuitstroom in vergelijking met eind 2007 fors gestegen. Toen stroomden er in totaal ruim 2.600 werknemers uit bij de bedrijven in de Metalektro. Zoals gebruikelijk is het grootste deel van de uitgestroomde werknemers uitvoerend technisch personeel. Tussen juli en december 2008 had $72 \%$ van de bedrijven in de Metalektro uitstroom van uitvoerende technici. 2.450 uitvoerende technici vertrokken in de tweede helft van 2008 en dat is ruim de helft van al het vertrokken personeel bij de metalektrobedrijven. De uitstroom van technisch opgeleide verkopers is echter fors afgenomen ten opzichte van de eerste helft van 2008: met ongeveer 150 stroomden er minder dan de helft uit ten opzichte van zes maanden eerder. Van de overige functiecategorieën is de uitstroom vrij stabiel gebleven gedurende 2008 .

$\mathrm{Al}$ met al is de personeelsuitstroom in de tweede helft van 2008 niet zo sterk toegenomen als men gezien de crisis zou verwachten. Echter, de personeelsuitstroom heeft alleen betrekking op werknemers met een dienstverband van het bedrijf, maar bij veel bedrijven werken ook mensen op uitzend- of detacheringsbasis. Van veel van deze mensen is afscheid genomen in de tweede helft van 2008 (zie paragraaf 2.4). 
In figuur 2.4 wordt de ontwikkeling van de personeelsuitstroom sinds het begin van de arbeidsmarktmonitor weergegeven. In de eerste meting van de arbeidsmarktmonitor was het totaal aantal vertrokken werknemers in de Metalektro het hoogst: ongeveer 6.400 werknemers vertrokken toen bij de bedrijven in de Metalektro. Tot en met de eerste helft van 2005 daalde de uitstroom vervolgens tot ongeveer 3.650 werknemers. In de periode sindsdien kende de personeelsuitstroom een sterk fluctuerend karakter. Zo steeg de uitstroom in de tweede helft van 2005 tot bijna 6.000, om in de eerste helft van 2006 nog sterker te dalen tot ongeveer 3.350 vertrokken werknemers. In de tweede helft van 2007 werd de laagste personeelsuitstroom sinds het begin van de arbeidsmarktmonitor bereikt. Er vertrokken nog slechts zo'n 2.600 werknemers bij de metalektrobedrijven. In 2008 steeg de personeelsuitstroom weer aanzienlijk tot ongeveer 4.800 .

\subsection{Werkgelegenheidsontwikkelingen in 2008}

In figuur 2.5 wordt het percentage bedrijven in de Metalektro dat te kampen heeft met krimpende werkgelegenheid weergegeven. Ten opzichte van de eerste helft van 2008 is het aandeel bedrijven, dat met krimpende werkgelegenheid te kampen heeft, in alle functiecategorieën minimaal verdubbeld. Bijna een derde van de bedrijven in de Metalektro heeft nu last van krimpende werkgelegenheid voor uitvoerende technici.

\section{Figuur 2.5}

Percentage bedrijven dat te kampen heeft met krimpende werkgelegenheid, 2008

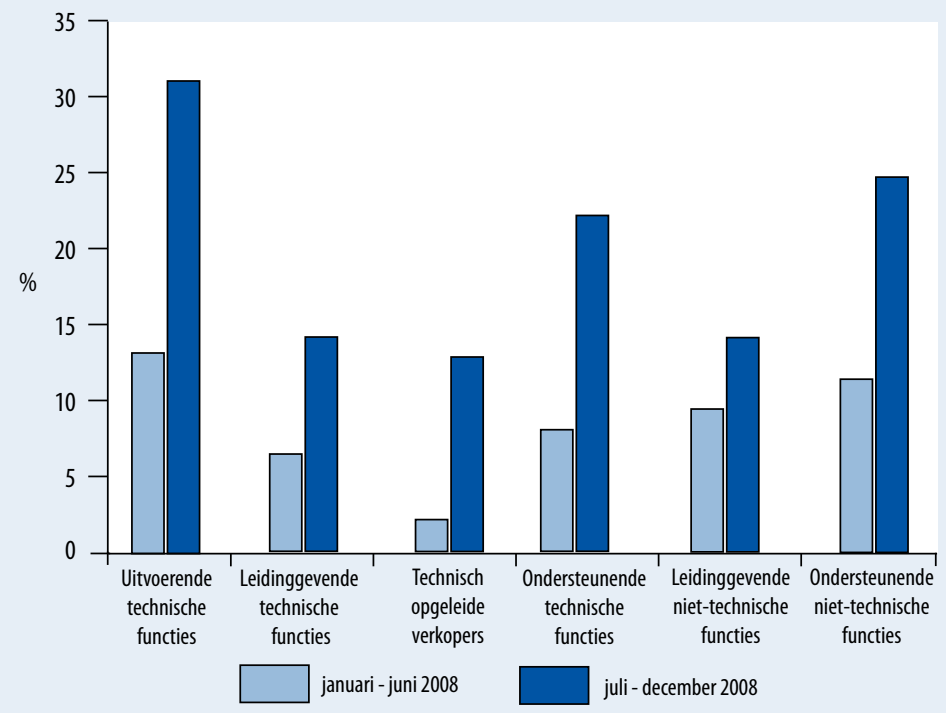

Bron: ROA / Werkgeverspanel Metalektro 
In de eerste helft van 2008 was dit nog maar $13 \%$. Met respectievelijk toenames van II\% naar $25 \%$ en van $8 \%$ naar $22 \%$ van de bedrijven zijn er ook relatief veel bedrijven met krimpende werkgelegenheid voor de ondersteunende niet-technische en technische functies. Voor de overige functiecategorieën heeft minder dan $15 \%$ van de bedrijven in de Metalektro teruglopende werkgelegenheid. Dat neemt niet weg dat het aandeel bedrijven met krimpende werkgelegenheid voor leidinggevende technische functies meer dan verdubbelde van $6 \%$ naar $14 \%$ en voor technisch opgeleide verkopers verzesvoudigde van $2 \%$ naar $13 \%$.

Er zijn dus in de tweede helft van 2008 fors meer bedrijven die met krimpende werkgelegenheid te kampen hebben dan in de eerste helft van het jaar. Dit wijst erop dat veel metalektrobedrijven de gevolgen van de crisis ondervinden. Figuur 2.6 geeft weer welke gevolgen van de krimpende werkgelegenheid de bedrijven verwachten.

\section{Figuur 2.6}

Gevolgen van krimpende werkgelegenheid (\% bedrijven met krimpende werkgelegenheid), 2008

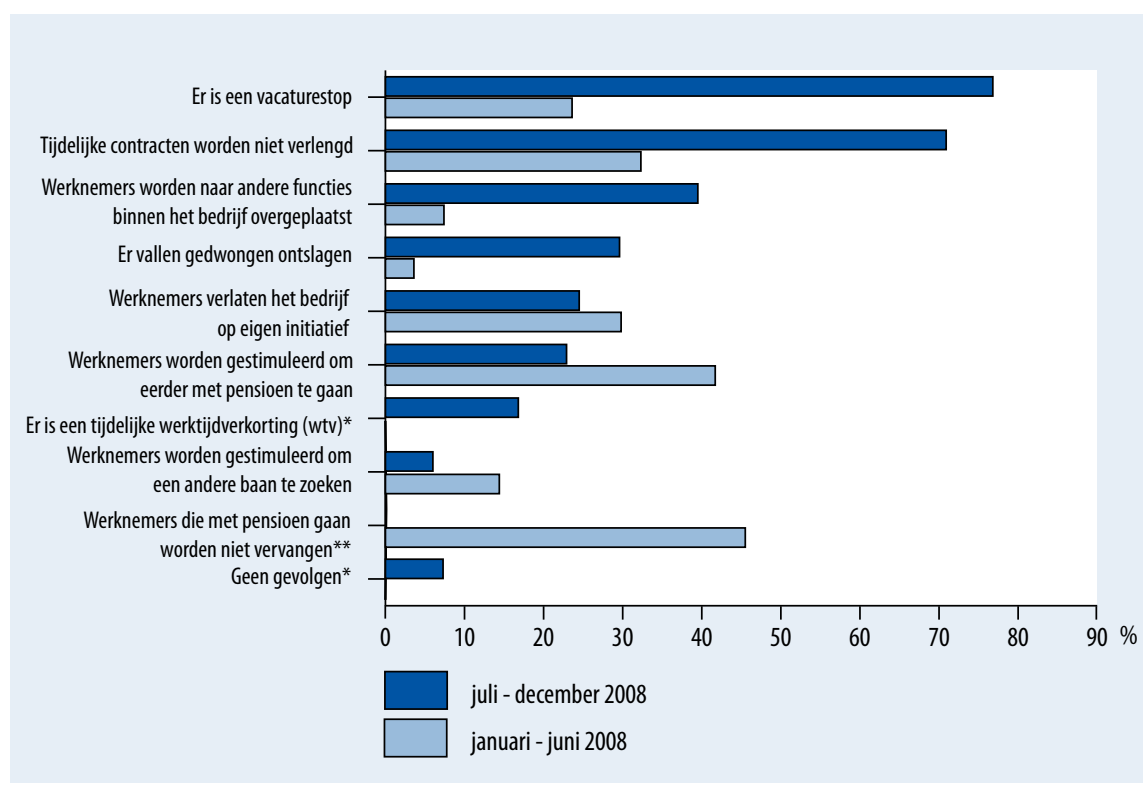

* Deze antwoordoptie is voor het eerst in de tweede meting 2008 opgenomen, vandaar dat voor deze antwoordoptie het percentage voor de periode januari-juni 2008 ontbreekt.

** Deze antwoordoptie is met ingang van de tweede meting 2008 komen te vervallen. Bron: ROA / Werkgeverspanel Metalektro

In de tweede helft van 2008 leidde de krimpende werkgelegenheid bij $77 \%$ van de bedrijven tot een vacaturestop terwijl bij $7 \mathrm{I} \%$ van de bedrijven tijdelijke contracten niet werden verlengd. Halverwege 2008 was dit nog slechts bij respectievelijk $24 \%$ en $32 \%$ van de bedrijven het geval. Bijna vier op de tien bedrijven heeft werknemers naar andere functies binnen het bedrijf overgeplaatst. Een maatregel die halverwege 
het jaar door nog slechts $7 \%$ van de bedrijven met krimpende werkgelegenheid werd doorgevoerd. De meest drastische maatregel die bedrijven met een krimpende werkgelegenheid kunnen nemen, is in het afgelopen half jaar veel vaker toegepast: tussen januari en juni gaf maar $4 \%$ van de bedrijven aan dat er gedwongen ontslagen vallen. Tussen juli en december is dit percentage ruim 7 keer zo hoog geworden: bij $30 \%$ van de bedrijven met werkgelegenheidskrimp vallen er gedwongen ontslagen. Bij ongeveer een kwart van de bedrijven met krimpende werkgelegenheid verlaten werknemers het bedrijf op eigen initiatief. Zes maanden eerder zei $30 \%$ van de bedrijven als gevolg van krimpende werkgelegenheid vrijwillig verloop te hebben. Het is daarom opmerkelijk dat bedrijven in de tweede helft van 2008 hun werknemers veel minder vaak dan in de eerste helft van 2008 stimuleren om eerder met pensioen te gaan: $23 \%$ van de bedrijven in de tweede helft van 2008 tegenover $42 \%$ in de eerste helft. In de eerste helft van 2008 gaf bijna de helft van de bedrijven aan werknemers die met pensioen gaan niet te vervangen. Vorig jaar kregen bedrijven die met minimaal $30 \%$ omzetverlies te kampen hadden de mogelijkheid om hun werknemers minder te laten werken. ${ }^{3}$ In de werktijdverkortingregeling worden deze niet-gewerkte uren betaald uit de WW. I7\% van de bedrijven in de Metalektro die met krimpende werkgelegenheid kampen maakt gebruik van tijdelijke werktijdverkorting. Er zijn ook bedrijven met krimpende werkgelegenheid die hier blijkbaar geen gevolgen van ondervinden. $7 \%$ van de bedrijven met krimpende werkgelegenheid gaf dit aan.

\subsection{Flexibel inlenen}

De personeelsuitstroom van mensen met een dienstverband is gedurende 2008 slechts licht gestegen, ondanks de intrede van de crisis in de tweede helft van 2008. Een logische verklaring hiervoor is dat de bedrijven in deze periode van economische neergang eerst afscheid nemen van hun flexibele schil, zodat zij hun vaste personeel in dienst kunnen houden. De vraag is dan ook of dit zich uit in een daling in het aantal flexibele arbeidskrachten in de Metalektro. In figuur 2.7 wordt het aantal flexibele arbeidskrachten in de Metalektro weergegeven.

Uit figuur 2.7 blijkt inderdaad dat het aantal flexibele arbeidskrachten bij de bedrijven in de Metalektro sterk is afgenomen in de loop van 2008. In de eerste helft van het jaar waren er 2I.IOo flexibele arbeidskrachten werkzaam in de Metalektro. In de tweede helft zijn dit er nog maar I2.700; een afname van maar liefst 40\%. Als gevolg van de crisis wordt vooral van veel flexibele arbeidskrachten geen gebruik meer gemaakt.

3. Om voor de regeling in aanmerking te komen moet een bedrijf in 2 maanden tijd een omzetverlies hebben gehad van minstens $30 \%$ ten opzichte van de voorafgaande 2 maanden. Bron: UWV. 
Figuur 2.7

Aantal flexibele arbeidskrachten in de Metalektro per functiecategorie, 2008

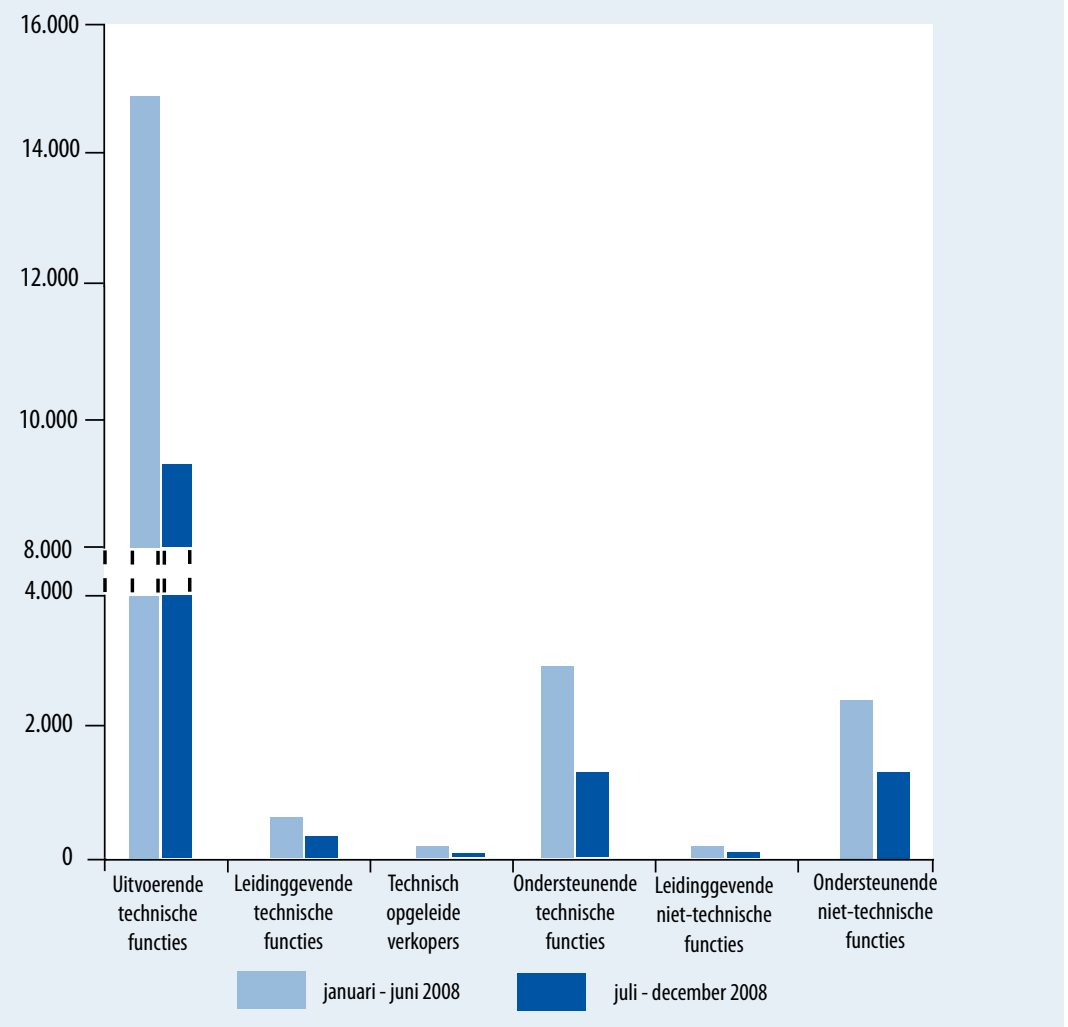

Bron: ROA / Werkgeverspanel Metalektro

Verreweg het grootste deel van de flexibele arbeidskrachten in de Metalektro wordt ingezet in uitvoerende technische functies: in de eerste helft van 2008 was $71 \%$ van de flexibele arbeidskrachten werkzaam in deze functies. In de tweede helft van het jaar steeg dit percentage zelfs tot $76 \%$. Tussen januari en juni 2008 werkten er $\mathbf{I} 4.900$ uitvoerende technici zonder contract bij bedrijven in de Metalektro. Tussen juli en december waren dit er nog maar 9.650. Van de ondersteunende technici zonder contract blijft in de tweede helft van 2008 nog maar 44\% over (van 2.900 naar I.275). Ook binnen de andere functiecategorieën neemt het aantal flexibele arbeidskrachten sterk af. Daarbij gaat het om dalingen met 40 tot $60 \%$. De gevolgen van de crisis blijven dus niet beperkt tot alleen de uitvoerende technici. 



\section{Vacatures en werving van personeel}

In het vorige hoofdstuk is gebleken dat veel bedrijven in de Metalektro te maken hebben met een uitstroom van personeel die groter is dan de instroom, waardoor er nog steeds vacatures ontstaan. In paragraaf $3 . I$ wordt dieper ingegaan op de uitstroom die ontstaat doordat personeel vrijwillig vertrekt. Vervolgens geeft paragraaf 3.2 een gedetailleerd beeld van de vacatures. Deze vacatures maken het aantrekken van nieuw personeel noodzakelijk, vandaar dat paragraaf 3.3 de verschillende wervingskanalen en hun effectiviteit onder de loep neemt. Tot slot komen in de vierde paragraaf de problemen aan bod die metalektrobedrijven ondervinden bij het werven van personeel en hoe zij daar mee omgaan.

\subsection{Vrijwillig vertrek van personeel}

Een deel van de in hoofdstuk 2 besproken personeelsuitstroom bestaat uit werknemers die het bedrijf vrijwillig hebben verlaten. In de eerste meting, die in de zomer van 2008 is uitgevoerd, zijn vragen gesteld over de achtergronden van het vrijwillig vertrek bij metalektrobedrijven. De in deze paragraaf weergegeven reacties zijn dus nog niet beïnvloed door de crisis. Figuur 3.I laat zien in welke mate bedrijven in 2008 geconfronteerd werden met vrijwillig vertrek van personeel in vergelijking tot het voorgaande jaar. In 2008 heeft $33 \%$ van de bedrijven erg weinig of geen verloop gekend en $32 \%$ weinig verloop. $8 \%$ van de metalektrobedrijven vindt echter dat ze veel verloop hebben gehad vergeleken met vorig jaar.

Een vergelijking tussen de antwoorden van 2008 en 2007 laat zien dat het percentage bedrijven dat erg weinig of geen verloop heeft sterk is gedaald van $45 \%$ in 2007 naar $33 \%$ in 2008 . Aan de andere kant is het percentage bedrijven dat weinig vrijwillig vertrek heeft gehad in vergelijking tot het jaar ervoor gestegen van $23 \%$ in 2007 tot $32 \%$ in 2008 . Verder is in figuur 3.I te zien dat er in 2008 minder bedrijven zijn die veel vrijwillig vertrek hebben gehad: in 2007 vond $14 \%$ van de bedrijven dat zij veel vrijwillig vertrek hebben gehad, in 2008 is dit gedaald tot $8 \%$.

Kort samengevat lijkt het er op dat de spreiding van de mate van vrijwillig vertrek in 2008 minder extreem is dan in 2007. Immers, aan de ene kant zijn er in 2008 minder bedrijven die veel vertrek of erg weinig tot geen vertrek hebben gehad dan in 2007 . Aan de andere kant zijn er in 2008 meer bedrijven geweest die met gemiddeld of weinig vrijwillig vertrek te maken hebben gehad. 


\section{Figuur 3.1}

Personeelsverloop van technisch personeel ten opzichte van een jaar eerder, 2007-2008 (\% bedrijven)

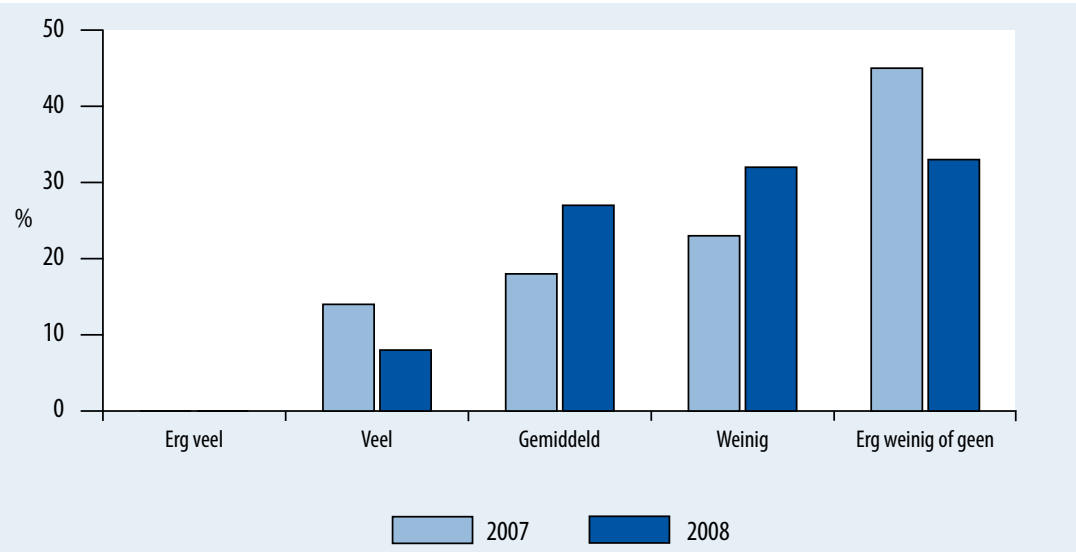

Bron: ROA / Werkgeverspanel Metalektro

Het vrijwillig personeelsverloop heeft verschillende oorzaken. De belangrijkste oorzaak is ontevredenheid met het salaris. Uit figuur 3.2 blijkt dat een derde van de bedrijven dit als belangrijkste vertrekreden noemt. Volgens een kwart van de bedrijven vertrekken werknemers uit onvrede met hun baan: $21 \%$ van de bedrijven wijt het vertrek van hun medewerker aan onvoldoende loopbaanperspectief. I4\% van de bedrijven denkt dat de combinatie werk-privé de boosdoener is geweest of dat het werk inhoudelijk niet interessant genoeg was (I2\%). Iets meer dan IO\% van de bedrijven geeft aan dat werknemers zijn vertrokken omdat het gras elders groener is of omdat men toe is aan een nieuwe uitdaging. Tot slot heeft een kleine IO\% van de bedrijven te maken met vrijwillig vertrek in verband met privé-omstandigheden of woon-werkverkeer.

Wanneer de meest genoemde vertrekredenen in 2008 worden vergeleken met die in 2007 , dan valt op dat ontevredenheid met het salaris in 2008 de meest voorkomende vertrekreden is, terwijl dit in 2007 ontevredenheid over de huidige baan was. Ontevredenheid met het salaris is ook één van de weinige vertrekredenen die dit jaar door iets meer bedrijven wordt genoemd dan vorig jaar: $32 \%$ in 2008 tegenover $26 \%$ in 2007. Ook worden moeilijkheden om werk en privé goed met elkaar te kunnen combineren dit jaar vaker genoemd dan vorig jaar: $14 \%$ van de bedrijven in 2008 tegenover IO\% van de bedrijven in 2007.

De andere vertrekredenen worden in 2008 door minder bedrijven genoemd dan in 2007. Vooral de daling van de reden "Betere mogelijkheden elders/toe aan nieuwe uitdaging" van $28 \%$ van de bedrijven in 2007 naar slechts I2\% van de bedrijven in 2008 is opmerkelijk. Daarnaast vertrok in 2007 bij I8\% van de bedrijven nog iemand omdat het reizen of andere privé-omstandigheden een te groot obstakel vormden. In 2008 komt dit slechts bij 9\% van de bedrijven voor. Het is mogelijk dat deze laatste 
twee dalingen er mee te maken hebben dat in 2008 meer werknemers het gevoel hebben goed op hun plek te zitten dan in 2007.

\section{Figuur 3.2}

De belangrijkste reden voor vrijwillig vertrek van technisch personeel naar een ander bedrijf, 20072008 (\% bedrijven)

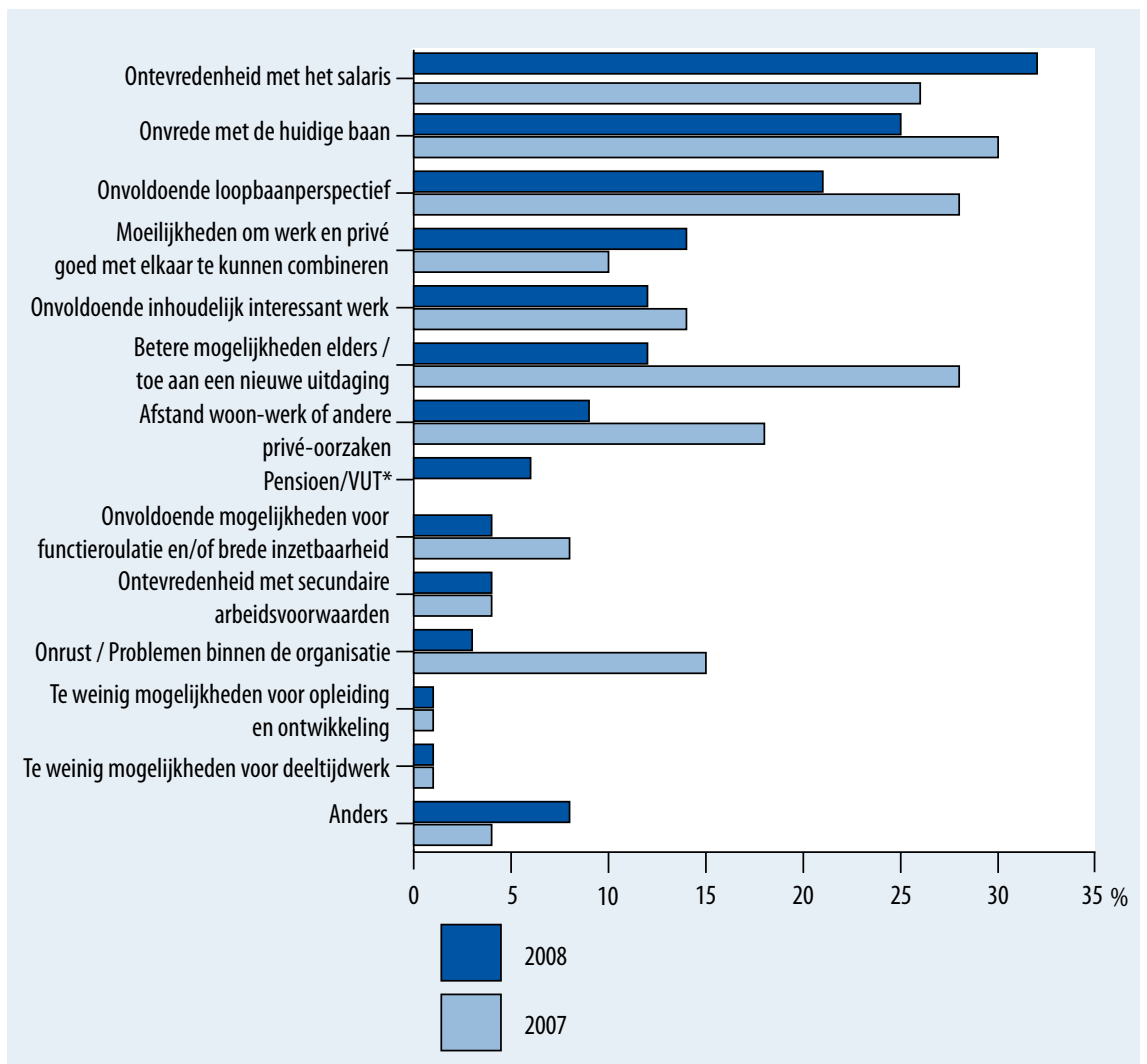

* Deze antwoordoptie is verkregen uit de antwoorden van de categorie 'Anders', vandaar dat het percentage voor 2007 ontbreekt.

Bron: ROA / Werkgeverspanel Metalektro

De meeste bedrijven proberen op verschillende manieren het vertrek van hun technisch personeel te voorkomen. Twee derde van de bedrijven probeert werknemers aan zich te binden door goede ontwikkelings- en opleidingsmogelijkheden en door de werknemerstevredenheid te bevorderen (zie figuur 3.3). Iets meer dan de helft van de metalektrobedrijven doet zijn best om de werknemers inhoudelijk interessant werk te bieden. Ook zegt ruim $40 \%$ van de bedrijven een concurrerend salaris en goede secundaire arbeidsvoorwaarden aan te bieden. Verder stimuleert een even grote groep bedrijven functieroulatie of brede inzetbaarheid in de strijd om het behoud van de werknemers. Onder de bedrijven is er iets minder aandacht voor het bieden van een goed loopbaanperspectief (34\%), mogelijkheden voor het combineren van werk-privé 
(20\%) en mogelijkheden om in deeltijd te werken (I2\%). Veel bedrijven realiseren zich overigens heel goed dat goede mogelijkheden om werk en privé te kunnen combineren de aantrekkelijkheid van het bedrijf als werkgever verhoogt. Uit de Quickscan blijkt dat bijna driekwart van de bedrijven dit een belangrijke factor vindt die de aantrekkelijkheid van een werkgever bepaalt. ${ }^{\text {I }}$ Over het algemeen sluiten de genomen maatregelen om ongewenst personeelsverloop te voorkomen vrij goed aan bij de meestgenoemde vertrekredenen uit figuur 3.2.

\section{Figuur 3.3}

Maatregelen ter voorkoming van het vertrek van technisch personeel naar andere bedrijven, 20072008 (\% bedrijven)

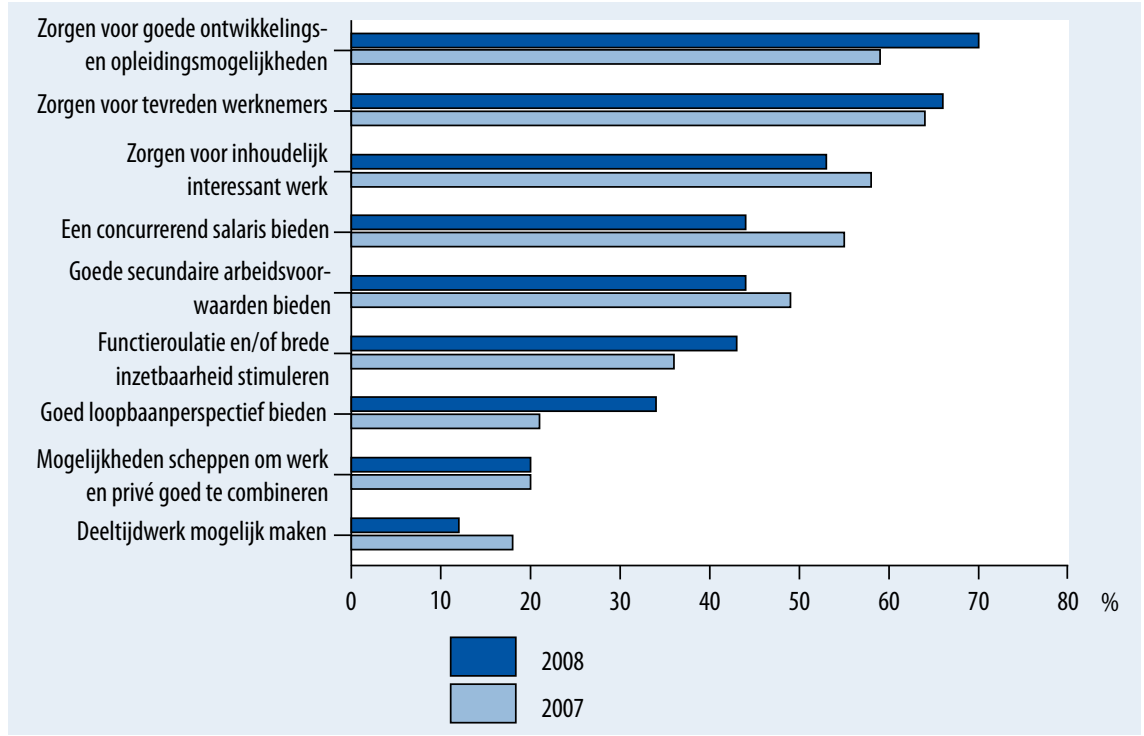

Bron: ROA / Werkgeverspanel Metalektro

In vergelijking tot vorig jaar is er een aantal verschuivingen te zien in de maatregelen die bedrijven nemen om personeel aan zich te binden en zo verloop tegen te gaan. Zo nemen meer bedrijven dan vorig jaar maatregelen op het gebied van ontwikkelingsen opleidingsmogelijkheden, functieroulatie en brede inzetbaarheid en loopbaanperspectief. Vooral de laatste verschuiving is interessant. Immers, in de vorige Monitor ${ }^{2}$ is aangegeven dat de aandacht van bedrijven voor het bieden van een goed loopbaanperspectief achterblijft bij de relatieve frequentie waarmee bedrijven werknemers door een gebrekkig loopbaanperspectief zien vertrekken. In 2007 noemde namelijk $28 \%$ van de bedrijven onvoldoende loopbaanperspectief als reden van vrijwillig vertrek terwijl in diezelfde periode slechts $21 \%$ van de bedrijven het bieden van een goed

I. In hoofdstuk 5 wordt dieper ingegaan op de mogelijkheden die bedrijven hun personeel aanbieden om werk en privé goed met elkaar te kunnen combineren.

2. Kriechel, B., A. de Grip, J. Coenen (2008), Arbeidsmarktmonitor Metalektro Editie 2008, ROA-R2008/2, Researchcentrum voor Onderwijs en Arbeidsmarkt, Universiteit Maastricht. 
loopbaanperspectief als een manier zag om vrijwillig vertrek te voorkomen. Nu noemt nog slechts $2 \mathrm{I} \%$ van de bedrijven het ontbreken van een goed loopbaanperspectief als reden voor vrijwillig vertrek en probeert maar liefst $34 \%$ van de bedrijven vrijwillig vertrek te voorkomen door hun personeel goed loopbaanperspectief te bieden.

Aan de andere kant nemen er minder bedrijven dan in 2007 maatregelen die gericht zijn op inhoudelijk interessant werk, goede secundaire arbeidsvoorwaarden en deeltijdwerk. Ook zag in 2007 55\% van de metalektrobedrijven het bieden van een concurrerend salaris als middel om vrijwillig verloop te voorkomen, terwijl dat in 2008 nog maar voor $44 \%$ van de bedrijven geldt. Gezien het feit dat ontevredenheid over het salaris in 2008 de meestgenoemde vertrekreden is (zie figuur 3.2), lijkt het van belang dat bedrijven het bieden van een concurrerend salaris niet onderschatten als maatregel om vrijwillig vertrek te voorkomen.

Uit de inhoud van deze paragraaf kan geconcludeerd worden dat werknemers in de Metalektro die vrijwillig vertrekken belang hechten aan een baan die goed betaalt en voldoende inhoudelijke diepgang en uitdaging biedt, zowel nu als in de toekomst. De reacties van de bedrijven laten zien dat zij over het algemeen adequaat op deze wensen proberen in te spelen. Uit de monitormeting die in de zomer van 2009 plaatsvindt, zal blijken of de crisis de achtergronden van het vrijwillig vertrek in de Metalektro heeft beinvloed.

\subsection{Vacatures}

De omvang van de instroom en uitstroom van personeel is in de loop van 2008 behoorlijk veranderd (zie hoofdstuk 2). In de eerste zes maanden van 2008 namen zowel de personeelsinstroom als de personeelsuitstroom sterk toe. In figuur 3.4 is te zien dat het aantal vacatures in de eerste helft van 2008 is toegenomen tot een recordhoogte van bijna 6.300 vacatures. Ten opzichte van de tweede helft van 2007 betekent dit een toename met maar liefst 1.700 vacatures. Daarentegen is in de tweede helft van 2008 de personeelsuitstroom nagenoeg gelijk gebleven ten opzichte van de eerste helft van 2008, maar daalde de personeelsinstroom van 6.900 naar 4.500 personen in diezelfde periode. Als gevolg hiervan laat figuur 3.4 een scherpe daling van het totale aantal vacatures in de Metalektro zien tot nog 'slechts' 2.440 vacatures. Met dit aantal vacatures bevindt de Metalektro zich eind 2008 op hetzelfde lage niveau als in 2003. Het lijkt er op dat de verslechterde economische situatie de oververhitte arbeidsmarkt in de Metalektro middels een flinke koude douche heeft afgekoeld. 


\section{Figuur 3.4}

Ontwikkeling totaal aantal vacatures in de Metalektro, 2002-2008

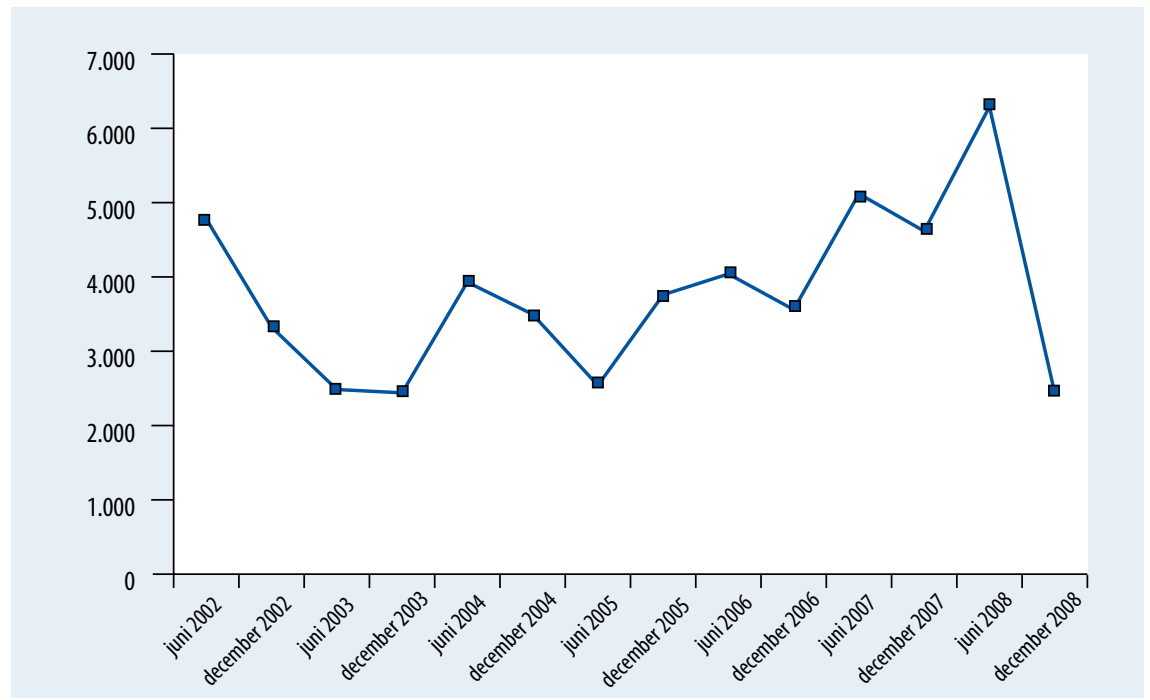

Bron: ROA / Werkgeverspanel Metalektro

\section{Figuur 3.5}

Openstaande vacatures per functiecategorie, 2008 (\% bedrijven)

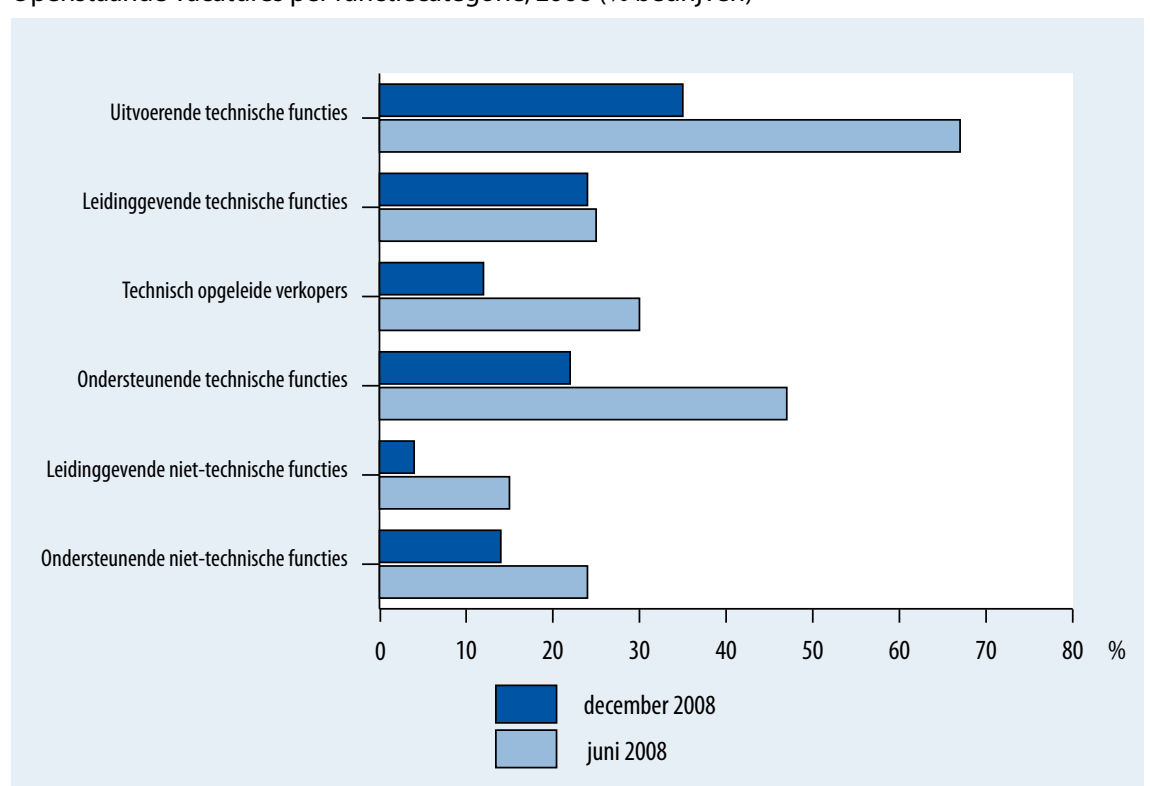

Bron: ROA / Werkgeverspanel Metalektro 
De scherpe daling van het aantal vacatures in de Metalektro is overigens niet gelijk verdeeld over de verschillende functiecategorieën. Het percentage bedrijven dat iemand zoekt voor een leidinggevende functie is vrijwel onveranderd gebleven: $25 \%$ eind 2008 tegenover $24 \%$ halverwege 2008 (zie figuur 3.5 ). Echter, voor de andere vijf functiecategorieën geldt dat het percentage bedrijven dat een vacature heeft in de betreffende functiecategorie gemiddeld is gehalveerd tussen juni 2008 en december 2008 . Eind 2008 heeft bijvoorbeeld nog maar I van de 3 bedrijven een vacature voor een uitvoerende technische functie, terwijl dit een half jaar daarvoor nog bij 2 van de 3 bedrijven het geval was. $12 \%$ van de bedrijven zoekt eind 2008 nog een technisch opgeleide verkoper tegenover $30 \%$ van de bedrijven medio 2008 . Verder is het percentage metalektrobedrijven dat een ondersteunende technicus nodig heeft gedaald van $47 \%$ naar $22 \%$. Ook van de vraag naar niet-technische functies en dan vooral leidinggevende niet-technische functies is weinig meer over: slechts $4 \%$ van de bedrijven zoekt een niet-technische leidinggevende tegenover $15 \%$ van de bedrijven een half jaar daarvoor.

\section{Figuur 3.6}

Aantal openstaande vacatures per functiecategorie (linkeras) en procentuele afname tussen juni en december (rechteras), 2008

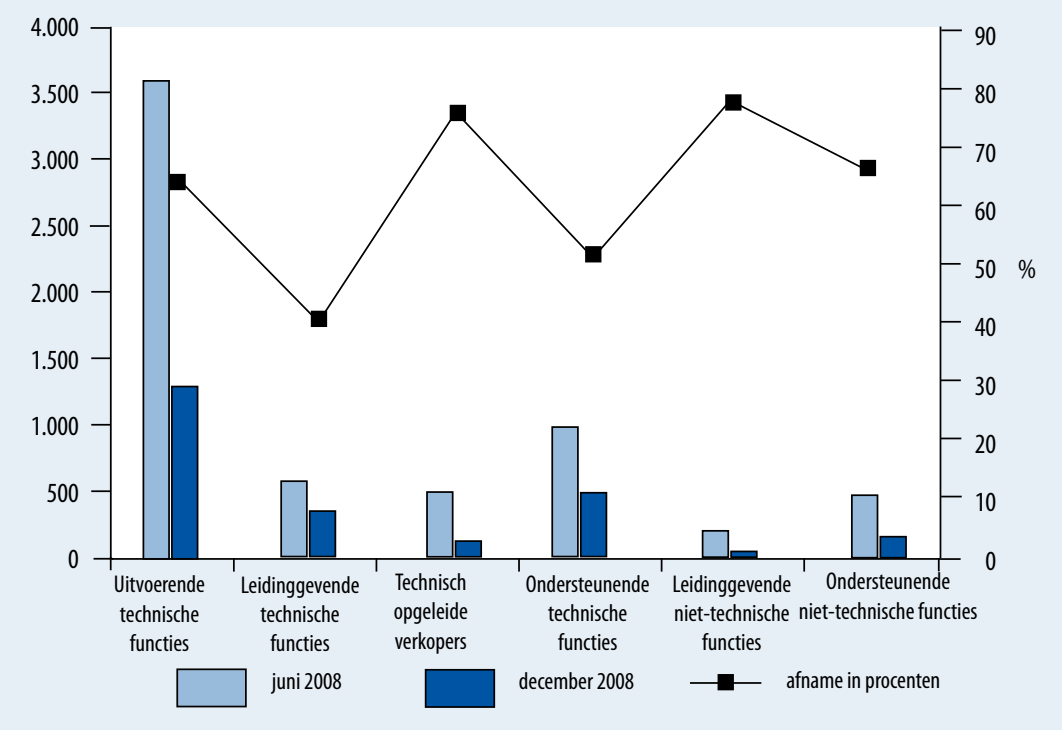

Bron: ROA / Werkgeverspanel Metalektro

Ook figuur 3.6 laat zien dat de daling in de vacatures verschilt tussen de functiecategorieën. Absoluut gezien is de vraag naar uitvoerende technici het meest gedaald. Het aantal vacatures voor uitvoerende technici daalde tussen juni en december 2008 met 2.300 vacatures: van 3.600 naar I.300 vacatures. Dit komt overeen met een daling van $64 \%$. De daling in de vacatures voor leidinggevende technici is daarentegen procentueel gezien het kleinst: 
'slechts' $40 \%$ minder vacatures dan medio 2008. Toch gaat het hier om een afname van 230 vacatures: van 570 vacatures in juni 2008 naar 340 vacatures aan het einde van 2008.

Ook de vraag naar technisch opgeleide verkopers is drastisch verminderd met $76 \%$. In absolute aantallen komt dit overeen met een daling van 370 vacatures: medio 2008 werden 490 technisch opgeleide verkopers gezocht, eind 2008 nog slechts I20. Verder is het aantal vacatures voor ondersteunende technische functies gehalveerd van 970 naar 480 vacatures. De vraag naar niet-technisch personeel is zelfs nog sterker afgenomen dan de vraag naar technisch personeel. Het aantal vacatures voor leidinggevende niet-technici nam af met maar liefst $78 \%$ (van 198 naar 43 vacatures) en voor ondersteunende niet-technici met $66 \%$.

De vacatures voor uitvoerende en ondersteunende technische functies worden in de figuren 3.7 en 3.8 meer in detail besproken. Figuur 3.7 maakt duidelijk dat er eind 2008 nog 250 vacatures zijn voor laag en ongeschoold technisch personeel. Daarnaast zijn metalektrobedrijven ook nog regelmatig op zoek naar montage personeel (200 vacatures), machinaal verspanend personeel (I60 vacatures) en lassers (I55 vacatures). Er is een duidelijke verschuiving in de vacatures te zien tussen 2007 en 2008: de vraag naar medewerkers voor de montage en de machinaal verspanende beroepen is sterk gedaald, terwijl de vraag naar laag en ongeschoold technisch personeel en lassers vrijwel gelijk is gebleven. Ook de vraag naar overige geschoolde technische vaklieden, bankwerkers en elektromonteurs is aanzienlijk gedaald. De vraag naar pijpverwerkende en plaatverwerkende beroepen is daarentegen vrijwel gelijk gebleven tussen 2007 en 2008.

\section{Figuur 3.7}

Aantal openstaande vacatures voor uitvoerende technische functies, 2007-2008

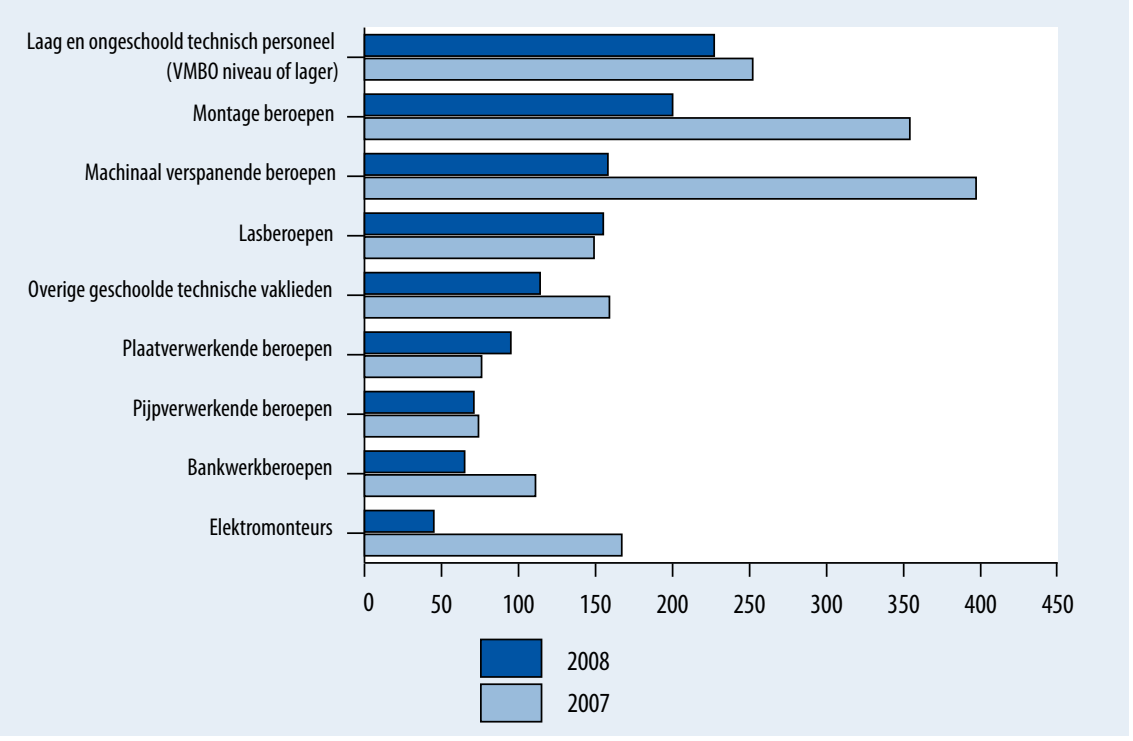

Bron: ROA / Werkgeverspanel Metalektro 
In figuur 3.8 is te zien dat metalektrobedrijven bij de ondersteunende technische functies eind 2008 vooral op zoek zijn naar personeel om de vacatures voor overige technische beroepen op MBO niveau en hoger te vervullen (300 vacatures). Net als bij de uitvoerende technische functies in de vorige figuur, is de vraag naar de meeste specifieke ondersteunende technische functies in 2008 aanzienlijk lager dan in 2007. De vraag naar functies die vallen onder de overige technische beroepen (MBO of hoger) is bijvoorbeeld met een derde (-I60 vacatures) afgenomen en het aantal vacatures voor proces engineers daalde maar liefst met de helft van I25 naar 60 vacatures. Daarentegen is de vraag naar werkvoorbereiders licht gestegen met 20 vacatures.

\section{Figuur 3.8}

Aantal openstaande vacatures voor ondersteunende technische functies, 2007-2008

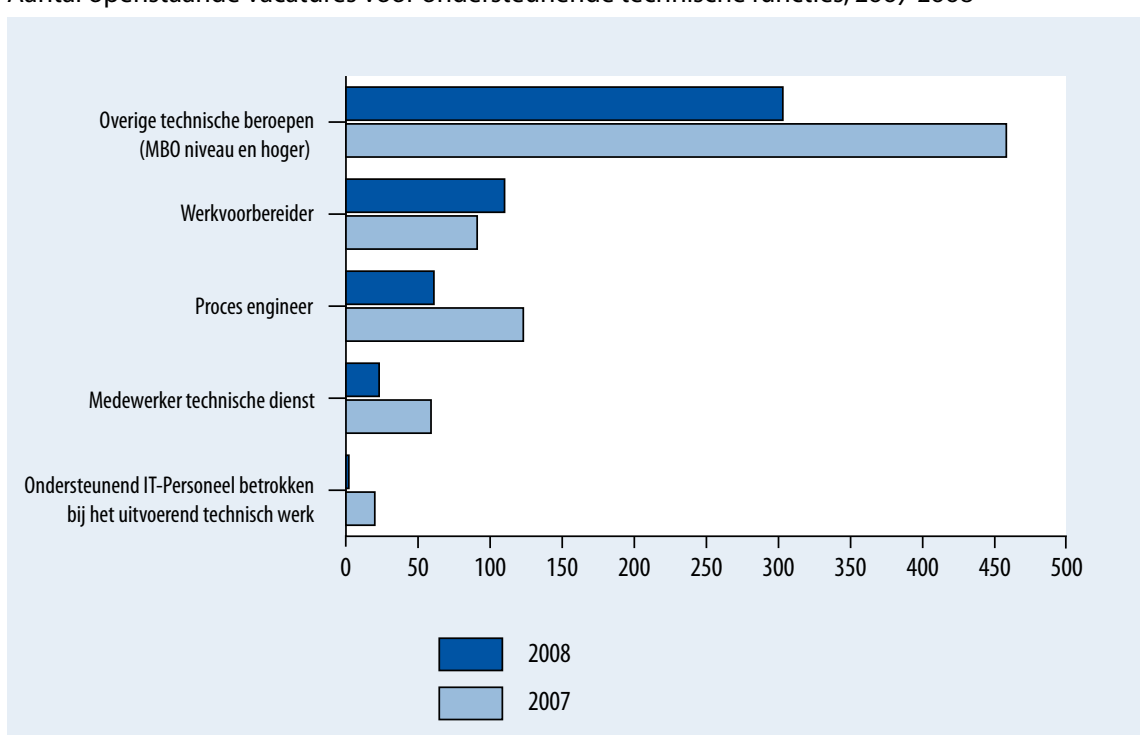

Bron: ROA / Werkgeverspanel Metalektro

De daling van het aantal vacatures laat duidelijk zien dat de arbeidsmarkt van de Metalektro minder krap is geworden in 2008. Echter, naast het aantal vacatures is ook de tijd dat deze vacatures open staan van belang om een uitspraak te kunnen doen over de arbeidsmarktkrapte. In december 2008 staat $22 \%$ van de vacatures o tot 3 maanden open en eenzelfde percentage vacatures staat 3 tot 6 maanden open (zie figuur 3.9). De meerderheid van de vacatures staat echter al langer open: $38 \%$ van de vacatures blijft 6 tot 12 maanden onvervuld en voor I8\% van de vacatures wordt een jaar of langer naar een geschikte kandidaat gezocht. Figuur 3.9 laat ook zien dat het percentage kort openstaande vacatures afneemt terwijl het percentage lang openstaande vacatures snel oploopt in de periode 2005-2008. Zo staat in juni $200567 \%$ van de vacatures en in december 2005 zelfs $8 \mathrm{I} \%$ van de vacatures slechts o tot 3 maanden open. Eind 2008 staat nog slechts $22 \%$ van de vacatures o tot 3 maanden open. Daarentegen stond in 
juni 2005 slechts $8 \%$ van de vacatures 6 tot I2 maanden open. Drieënhalf jaar later was deze groep vacatures al gegroeid tot maar liefst $38 \%$ van het totale aantal vacatures. Enerzijds is de arbeidsmarkt dus minder krap geworden als gevolg van het gedaalde aantal vacatures. Anderzijds is de 'resterende' krapte er wel één die zeer hardnekkig is: de nog resterende vacatures zijn moeilijk in te vullen waardoor ze langer open blijven staan.

\section{Figuur 3.9}

Ontwikkeling van het aantal maanden dat vacatures voor technisch personeel open staan, 20052008 (\% van alle vacatures)

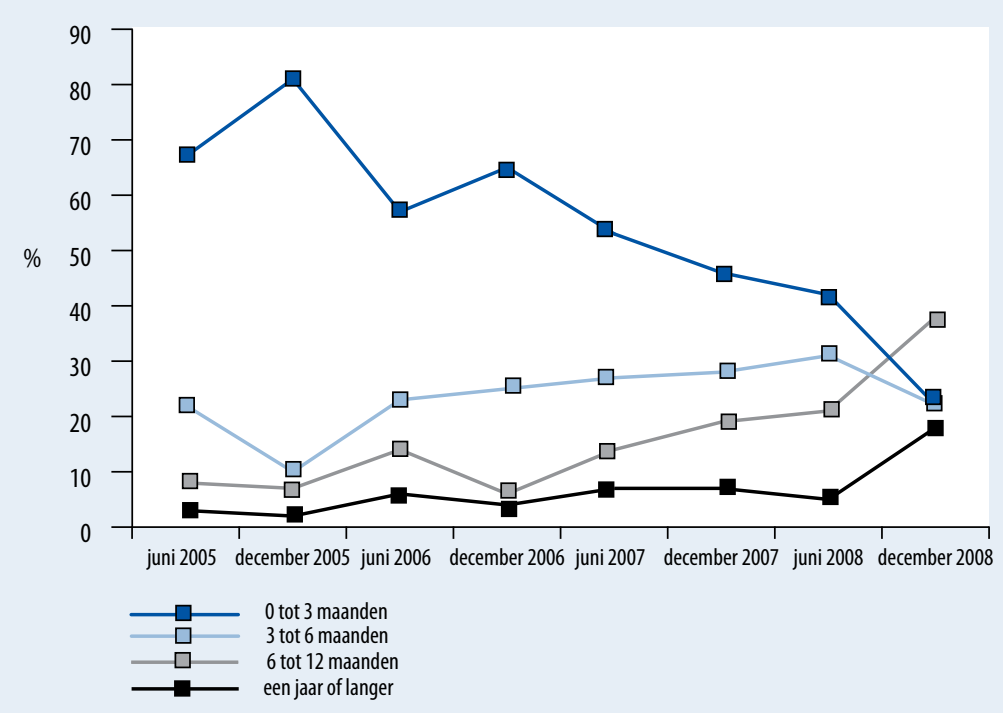

Bron: ROA / Werkgeverspanel Metalektro

De hiervoor besproken vacatures zijn meestal ontstaan doordat personeel uit zichzelf is vertrokken (7I\%). Dit is een beduidend hoger percentage dan in 2007 , toen $56 \%$ van de bedrijven vrijwillig vertrek van personeel als reden opgaf van de ontstane vacature. Bij eveneens $71 \%$ van de bedrijven is de groei van het bedrijf en/of de hoeveelheid werk de reden dat men personeel zoekt in 2008 tegenover $78 \%$ van de bedrijven in 2007. Daarnaast heeft I2\% van de bedrijven vacatures om het werk dat blijft liggen als gevolg van langdurig zieke werknemers op te vangen. Dit percentage is een verdubbeling ten opzichte van 2007 (6\%).

Zoals figuur 3.Io laat zien zijn de vacatures die eind 20086 maanden of langer open staan niet evenredig over alle regio's verdeeld. In de regio West staat 4 van de Io vacatures 6 maanden of langer open. Daarentegen is maar liefst $66 \%$ van alle vacatures in de regio Noord/Oost en $71 \%$ van alle vacatures in de regio Zuid al minimaal een half jaar onvervuld gebleven. Een vergelijking van deze percentages met de situatie 
in de zomer van 2008 laat nog eens zien hoe de aard van de vacatures is veranderd. Het aantal vacatures dat 6 maanden of langer open staat als percentage van het totaal aantal vacatures in de regio was medio $200836 \%$ in de regio West, $22 \%$ in de regio Noord/Oost en $17 \%$ in de regio Zuid.

\section{Figuur 3.10}

Percentage vacatures dat langer dan 6 maanden openstaat, december 2008 (\% van alle vacatures)

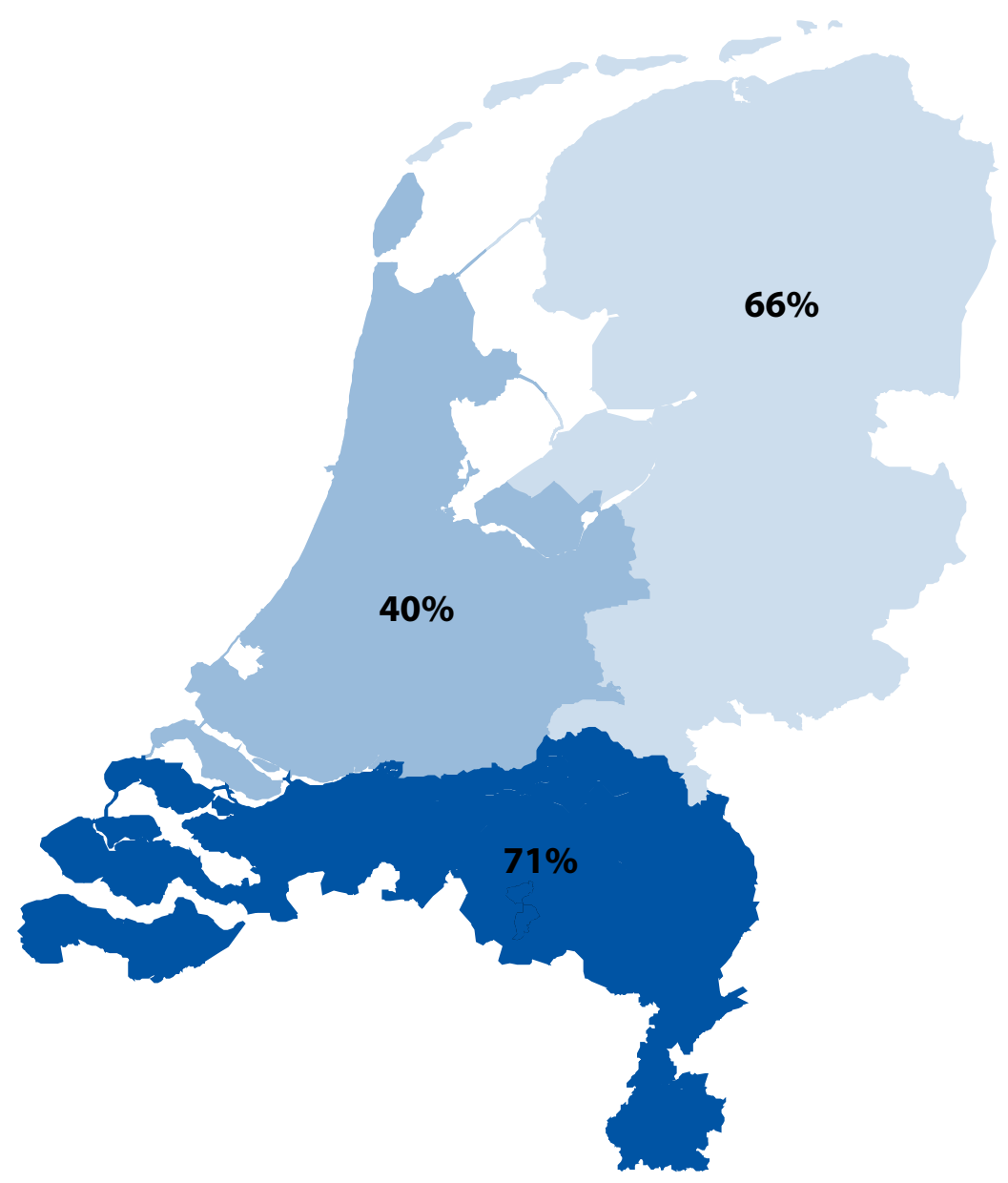

Bron: ROA / Werkgeverspanel Metalektro

Kortom, het totaal aantal vacatures is weliswaar sterk teruggelopen, maar de vacaturedaling is niet voor alle technische functies gelijk. Daarnaast lijken vooral de vacatures 
die nog maar relatief kort open stonden te zijn verdwenen en blijven bedrijven zitten met vacatures die al langere tijd open staan.

\subsection{Effectieve wervingskanalen}

Om goede innovatieve producten te kunnen blijven leveren is het voor de bedrijven in de Metalektro belangrijk om hun vacatures zo snel mogelijk in te vullen. Dit roept een aantal vragen op: hoe komen metalektrobedrijven aan nieuwe medewerkers, welke wervingskanalen gebruiken de bedrijven daarbij en hoe effectief zijn deze kanalen? Deze onderwerpen staan in paragraaf 3.3 centraal.

\section{Figuur 3.11a}

Meest effectieve wervingskanaal voor het werven van uitvoerend en ondersteunend technisch personeel, 2008 (\% bedrijven)*

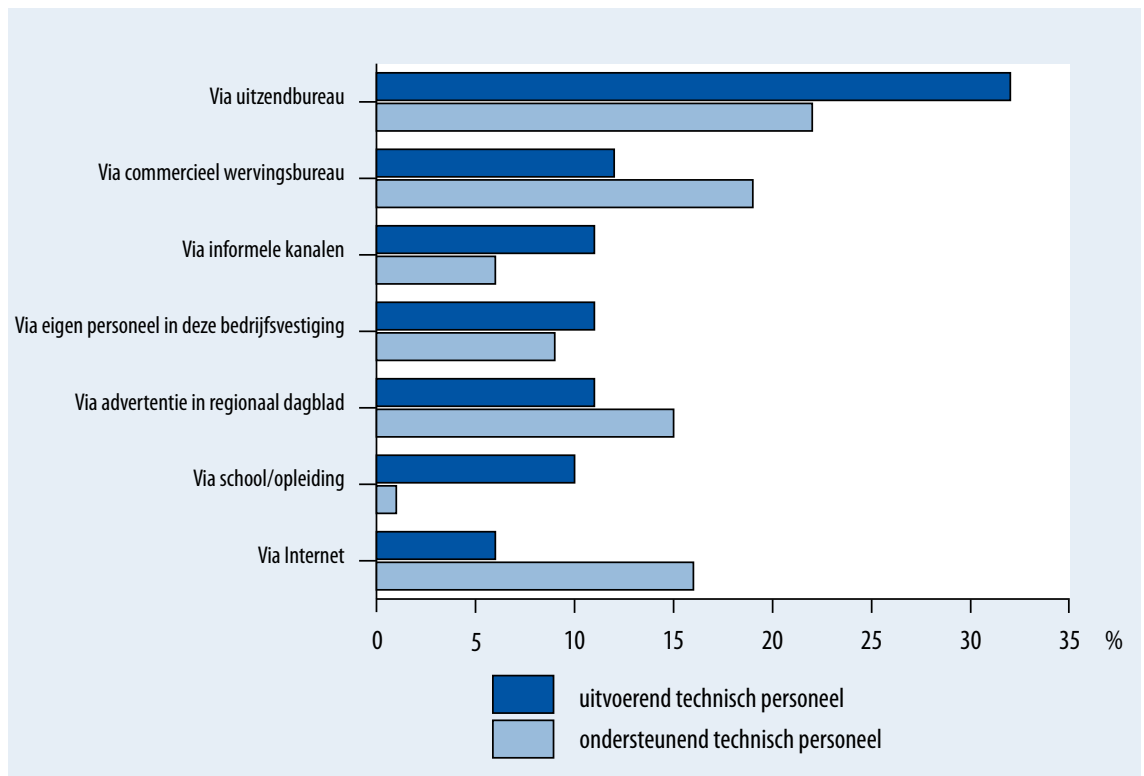

* De wervingskanalen die door minder dan $5 \%$ van de bedrijven zijn genoemd als meest belangrijke wervingskanaal voor beide functiecategorieën zijn weggelaten in deze figuur. Bron: ROA / Werkgeverspanel Metalektro

Figuur 3.IIa laat zien dat evenals vorig jaar het uitzendbureau het vaakst genoemd wordt als het meest effectieve wervingskanaal voor uitvoerend technisch personeel: $32 \%$ van de bedrijven tegenover $28 \%$ in 2007 . I2\% van de bedrijven vindt de commerciële wervingsbureaus de meest effectieve manier om aan uitvoerend technisch personeel te komen. De wervingskanalen eigen personeel, informele kanalen en een advertentie in een regionaal dagblad worden elk door II\% van de bedrijven het meest effectief gevonden. I op de Io bedrijven vindt het onderwijs het meest effectieve wervingskanaal voor uitvoerende technici. Dit is iets meer dan vorig jaar (3\%). Slechts $6 \%$ van 
de bedrijven vindt het internet het meest effectief tegenover $13 \%$ in 2007 . Het CWI (tegenwoordig opererend onder de naam UWV WERKbedrijf), externe relaties, advertenties in landelijke bladen of vakbladen en open sollicitaties worden daarentegen nauwelijks genoemd als het meest effectieve wervingskanaal.

Figuur 3.IIa laat verder zien dat de bedrijven in de Metalektro ook voor ondersteunend technisch personeel het liefst bij uitzendbureaus en commerciële wervingsbureaus aankloppen: ongeveer I op de 5 bedrijven geeft aan deze bureaus de voorkeur. In 2008 wordt het uitzendbureau iets minder vaak als effectief gezien dan in het jaar er voor: $22 \%$ in 2008 tegenover $27 \%$ in 2007 . Aan de andere kant worden commerciële wervingsbureau juist vaker dan in 2007 als het meest effectieve wervingskanaal gezien: $19 \%$ in 2008 tegenover $11 \%$ in 2007 . Ook adverteert $15 \%$ van de bedrijven graag in een regionaal dagblad vanwege de effectiviteit hiervan. Opvallend is dat $16 \%$ van de bedrijven bij het zoeken naar ondersteunend technisch personeel het internet het meest effectieve wervingskanaal vinden. Bij de zoektocht naar uitvoerend technisch personeel noemt namelijk slechts $6 \%$ van de bedrijven het internet als het meest effectieve wervingskanaal. De minst effectieve wervingskanalen voor ondersteunend technische functies zijn, net als bij de uitvoerende technische functies, externe relaties, open sollicitaties, het CWI en advertenties in landelijke dagbladen en vakbladen. Slechts I\% van de bedrijven vindt de school of opleiding een geschikte plaats om ondersteunend technisch personeel te werven. Bij het werven naar uitvoerend technisch personeel noemt namelijk nog I op de io bedrijven de school of opleiding als het meest effectieve wervingskanaal.

Wanneer metalektrobedrijven op zoek zijn naar leidinggevend technisch personeel vindt een derde van de bedrijven een commercieel wervingsbureau het meest effectief (zie figuur 3.IIb). I7\% van de bedrijven vindt het internet het meest effectieve wervingskanaal. Daarnaast vindt ruim IO\% van de bedrijven een uitzendbureau of een advertentie in een regionaal dagblad de meest effectieve manier om vacatures voor leidinggevende technici te vervullen. Het werven via een advertentie in een vakblad, het CWI, school of opleiding en open sollicitaties wordt door geen of slechts een enkel bedrijf als het meest effectieve wervingsmanier genoemd. De genoemde percentages zijn vrijwel gelijk aan die van 2007 .

Ook voor het werven van technisch opgeleide verkopers ervaren de meeste bedrijven een commercieel wervingsbureau als het meest effectief: $32 \%$ van de metalektrobedrijven heeft deze ervaring. Verder vindt $\mathrm{I} 4 \%$ van de bedrijven informele kanalen het meest effectief, gevolgd door het werven via internet en een advertentie in een regionaal dagblad met elk I2\% van de bedrijven. Het internet is echter minder populair dan een jaar geleden ( -9 procentpunten) terwijl de informele kanalen juist iets populairder geworden zijn ten opzichte van 2007 ( +5 procentpunten). Er zijn overigens nauwelijks metalektrobedrijven te vinden die het werven via CWI, open sollicitaties, of school/ opleiding als de meest effectieve manier zien om aan technisch opgeleide verkopers of leidinggevende technici te komen. 


\section{Figuur 3.11b}

Meest effectieve wervingskanaal voor het werven van leidinggevend technisch personeel en technisch opgeleide verkopers, 2008 (\% bedrijven)*

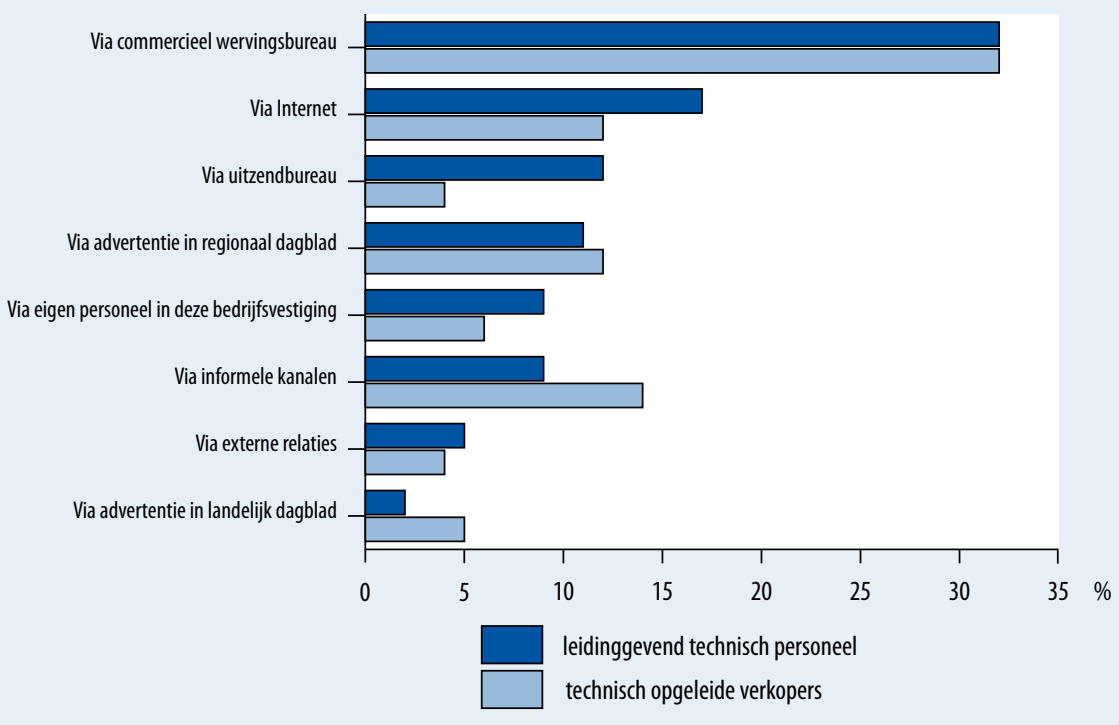

* De wervingskanalen die door minder dan 5\% van de bedrijven zijn genoemd als meest belangrijke wervingskanaal voor beide functiecategorieën zijn weggelaten in deze figuur.

Bron: ROA / Werkgeverspanel Metalektro

Bij het werven van personeel maken bedrijven in de Metalektro voor alle functiecategorieën graag gebruik van de expertise van uitzendbureaus of commerciële wervingsbureaus, omdat zij dit de meest effectieve wervingskanalen vinden. Deze voorkeur is niet verwonderlijk gelet op de algemene expertise op het gebied van werving en selectie die er in deze bureaus aanwezig is. Daarnaast kan het inschakelen van dergelijke bureaus een aanzienlijke tijdsbesparing opleveren voor de metalektrobedrijven die er gebruik van maken. Een mogelijk nadeel van deze strategie voor de lange termijn zou kunnen zijn dat metalektrobedrijven afhankelijk worden van deze bureaus omdat de bedrijven zelf geen wervings- en selectie-expertise opbouwen. Ook is het de vraag of een externe partij voldoende kennis heeft van de specifieke competenties die gevraagd worden in de Metalektro om de meest geschikte kandidaten te vinden.

\subsection{Wervingsproblemen en bijbehorende maatregelen}

Hoewel bedrijven in de Metalektro kunnen beschikken over diverse effectieve wervingskanalen (zie paragraaf 3.3) lukt het de bedrijven lang niet altijd om alle vacatures tijdig in te vullen. Het aantal vacatures is het afgelopen jaar weliswaar afgenomen, maar de vacatures die nog open staan, staan steeds langer open (zie paragraaf 
3.2). Deze paragraaf gaat in op de achtergrond van deze wervingsproblemen en op welke manier metalektrobedrijven deze problemen proberen aan te pakken.

In figuur 3.12 is te zien dat de wervingsproblemen vooral sinds 2004 flink zijn toegenomen. Het percentage bedrijven met geen, erg weinig en weinig wervingsproblemen is vanaf dat jaar steeds meer afgenomen: in 2008 heeft slechts $7 \%$ van de bedrijven geen wervingsproblemen gehad, $8 \%$ heeft erg weinig problemen gehad en nog eens $8 \%$ had weinig problemen. Het percentage bedrijven met gemiddeld, veel of erg veel problemen is daarentegen sterk gestegen sinds 2004. Zo kampt in $200831 \%$ van de metalektrobedrijven met gemiddelde wervingsproblemen, $34 \%$ met veel problemen en maar liefst $\mathbf{1} 2 \%$ met erg veel problemen.

\section{Figuur 3.12}

Ontwikkeling van het percentage bedrijven met problemen bij de werving van technisch personeel, 2002-2008 (\% bedrijven)

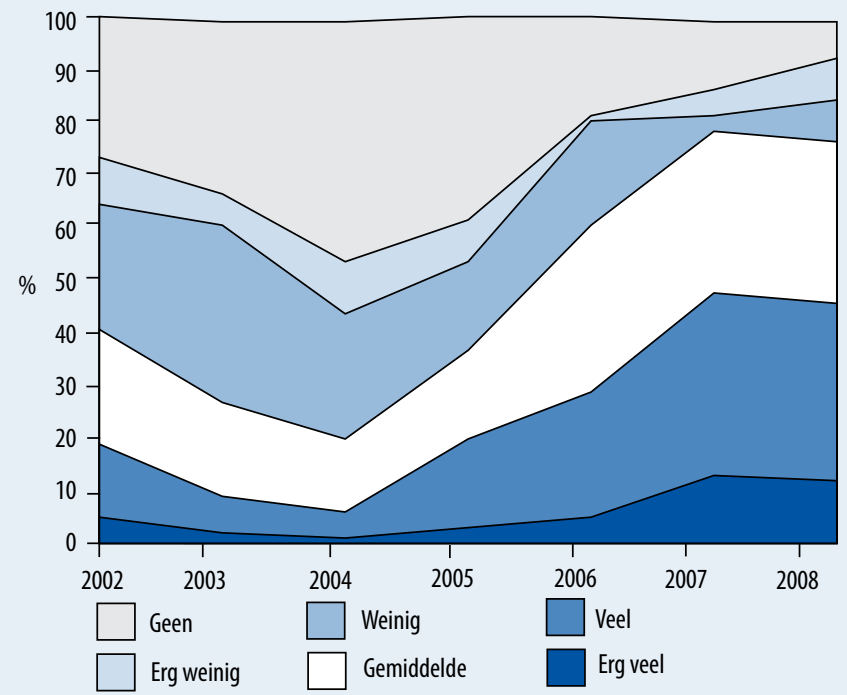

Bron: ROA / Werkgeverspanel Metalektro

Zoals figuur 3.13 laat zien, variëren de wervingsproblemen sterk per functiecategorie. De grootste problemen doen zich voor bij het vervullen van vacatures voor uitvoerende technische functies: $8 \mathrm{I} \%$ van de bedrijven heeft hier in 2008 problemen mee. Daarnaast zijn de wervingsproblemen in de afgelopen drie jaar steeds het grootst voor de uitvoerende technici én deze problemen zijn elk jaar weer iets groter geworden. Een zelfde trend van toenemende wervingsproblemen is ook te zien bij de ondersteunende technische functies. In 2006 heeft $38 \%$ van de bedrijven problemen met het vervullen van vacatures in deze functies, in $200743 \%$ en in $200846 \%$ van de bedrijven. 
Daarentegen laten de wervingsproblemen bij de leidinggevende technische functies een omgekeerd beeld zien: het percentage bedrijven dat problemen heeft met het invullen van leidinggevende technische posities is tussen 2006 en 2008 gedaald van $40 \%$ naar $22 \%$ van de bedrijven. Verder heeft in 2008 ongeveer een kwart van de bedrijven moeite om vacatures voor technisch opgeleide verkopers in te vullen. Dit is meer dan in 2007 ( $16 \%)$, maar vrijwel gelijk aan het percentage in $2006(25 \%)$.

\section{Figuur 3.13}

Percentage bedrijven dat problemen ondervindt bij het vervullen van technische functies per functiecategorie, 2006-2008

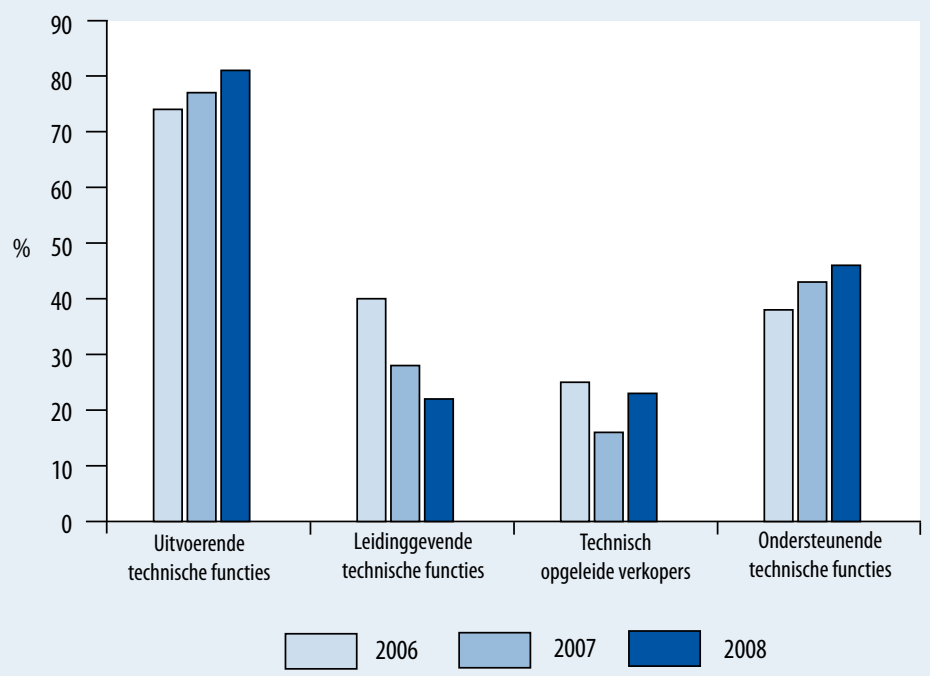

Bron: ROA / Werkgeverspanel Metalektro

De wervingsproblemen in de Metalektro komen vooral tot uiting in het gebrek aan sollicitanten (zie figuur 3.I4). 89\% van de metalektrobedrijven met wervingsproblemen heeft hier in 2008 mee te maken gehad. Dit percentage is opgebouwd uit $32 \%$ van de bedrijven met wervingsproblemen die te weinig aanbod hebben van sollicitanten met de juiste competenties, $15 \%$ heeft te weinig aanbod van sollicitanten met voldoende werkervaring en $22 \%$ heeft te weinig aanbod van sollicitanten met zowel de juiste competenties als voldoende werkervaring. De resterende $20 \%$ van de bedrijven vindt het aanbod van sollicitanten 'gewoon' te laag.

Een aantal bedrijven loopt ook tegen het probleem aan dat er weinig geschikte mensen van de opleiding afkomen (38\%), hoewel dit percentage lager is dan in 2007 (45\%). De eerdere krapte op de arbeidsmarkt is misschien wel de oorzaak van het hogere percentage bedrijven dat vindt dat sollicitanten te hoge salarissen vragen: $27 \%$ van de 
bedrijven in 2008 tegenover $19 \%$ van de bedrijven in 2007 . Verder merkt ruim I op de 5 bedrijven op dat zij in dezelfde personeelsvijver vissen als hun branchegenoten, terwijl I op de Io metalektrobedrijven concurreert met bedrijven buiten de branche om de juiste mensen aan te trekken. Deze 'war for talent' is in 2008 wel iets minder heftig dan in 2007 .

\section{Figuur 3.14}

Belangrijkste oorzaken van de ondervonden problemen bij het vervullen van vacatures voor technisch personeel, $2007-2008$ ( $\%$ bedrijven)

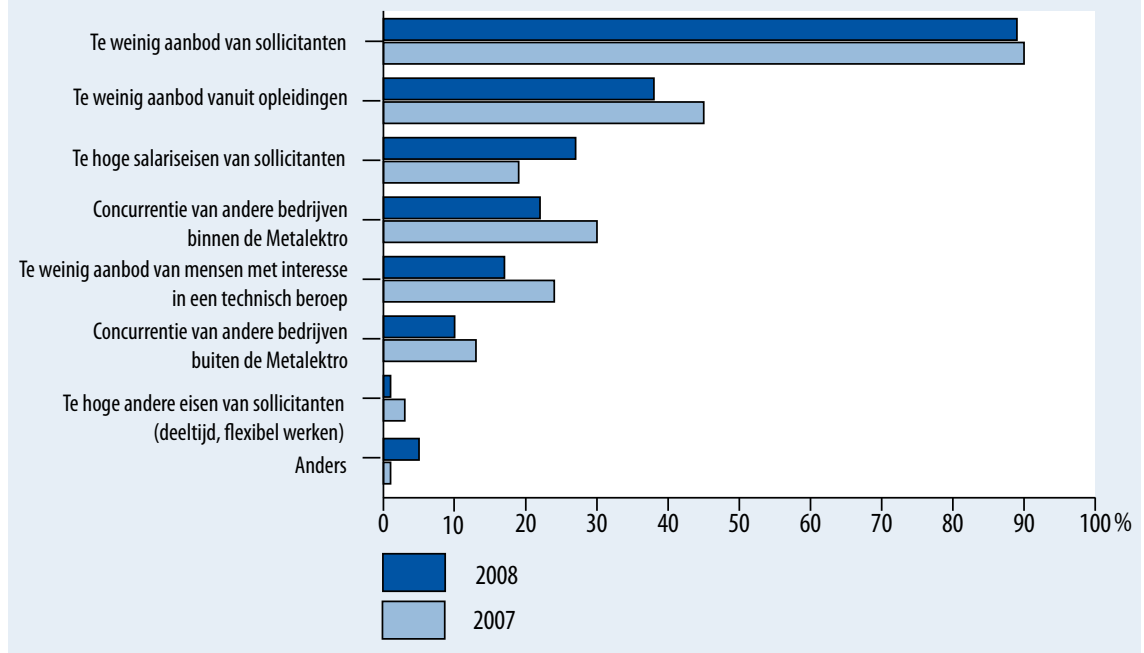

Bron: ROA / Werkgeverspanel Metalektro

Het niet tijdig kunnen vervullen van de nodige vacatures wordt vrijwel direct voelbaar in de bedrijven in de vorm van een toegenomen werkdruk: $73 \%$ van de bedrijven die te kampen hebben met wervingsproblemen zegt hier last van te hebben (zie figuur 3.15). Daarnaast krijgt $48 \%$ van de bedrijven te maken met stijgende wervings- of opleidingskosten en bij een derde van de bedrijven krijgt men het werk niet meer op tijd af. De genoemde gevolgen van de wervingsproblematiek worden in 2008 wel door een kleiner deel van de bedrijven genoemd dan in 2007. Andere gevolgen van onvervulde vacatures zijn langer wordende levertijden en minder innovatiemogelijkheden. Beide gevolgen kwamen in 2008 bij ongeveer een kwart van de metalektrobedrijven voor.

Gezien de ernst van de wervingsproblemen en de direct merkbare gevolgen van onvervulde vacatures is het duidelijk dat er actie dient te worden ondernomen. $83 \%$ van de bedrijven treft in 2008 maatregelen om met moeilijk vervulbare vacatures om te gaan. Dit percentage is lager dan in 2007 toen nog 9I\% van de bedrijven maatregelen trof. Een mogelijke verklaring voor dit verschil is dat relatief minder bedrijven direct last hebben van de gevolgen van wervingsproblemen (zie figuur 3.15). Ook is het denkbaar 
dat bedrijven die in 2007 maatregelen troffen, hier in 2008 de vruchten van hebben geplukt waardoor nieuwe maatregelen niet nodig zijn geweest.

\section{Figuur 3.15}

Direct merkbare gevolgen van het tekort aan technisch personeel, 2007-2008 (\% bedrijven)

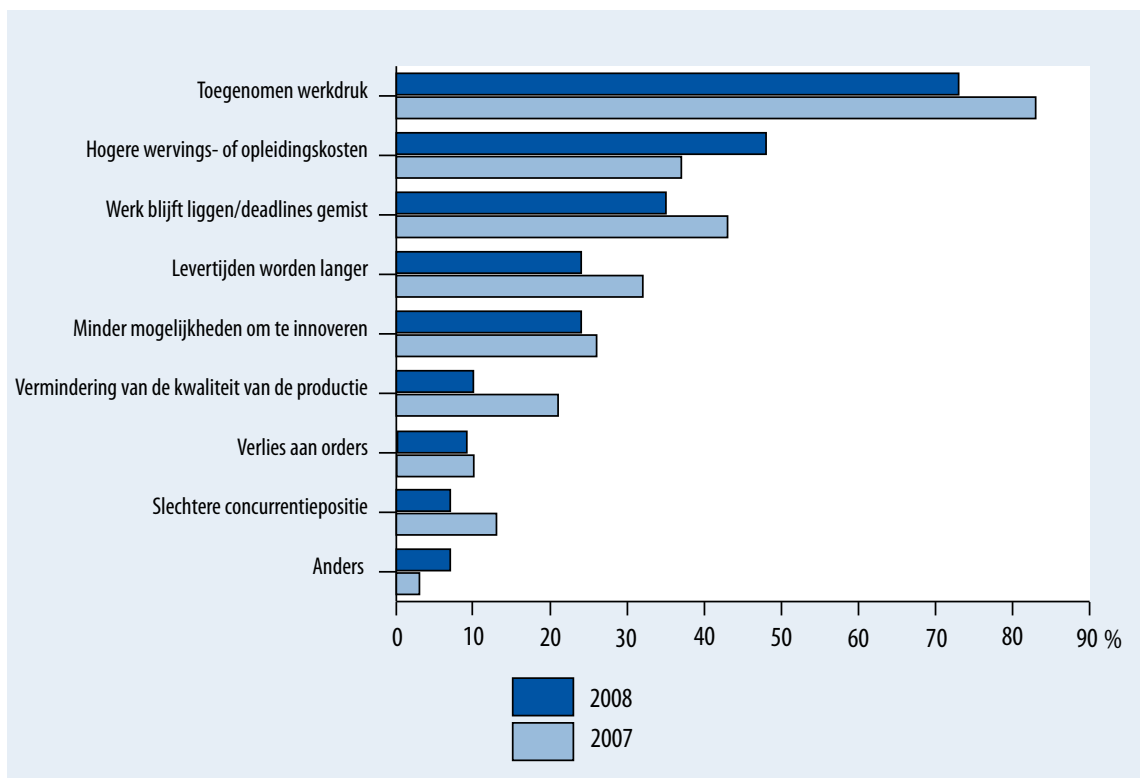

Bron: ROA / Werkgeverspanel Metalektro

De maatregelen die bedrijven treffen in verband met moeilijk vervulbare vacatures liggen enerzijds op het gebied van de werving en selectie en anderzijds op het terrein van de interne organisatie. Aan de bedrijven is niet alleen gevraagd welke maatregelen zij hebben getroffen maar ook hoe effectief de maatregelen waren. In de volgende alinea's worden allereerst de getroffen maatregelen op het gebied van werving en selectie en hun effectiviteit besproken. Daarna volgt een beschrijving van de veranderingen die bedrijven aanbrengen in de organisatie en de effectiviteit daarvan.

Volgens figuur 3.16 is in 2008 80\% van de bedrijven overgegaan tot het inschakelen van uitzendbureaus of andere commerciële wervingsbureaus. Het is dan ook de meest gebruikte maatregel, net als in voorgaande jaren. In 2007 maakte namelijk $76 \%$ van de bedrijven van deze bureaus gebruikt, in $200688 \%$ en in $200577 \%$. In 2008 vindt $85 \%$ van de bedrijven die externe bureaus inschakelen dit enigszins tot zeer effectief. Uitzend- en wervingsbureaus worden overigens het meest ingezet door bedrijven met 5I-IOO medewerkers (96\%), gevolgd door bedrijven met meer dan IOO medewerkers $(76 \%)$ en het minst door bedrijven met minder dan 50 medewerkers (67\%). Een mogelijke verklaring hiervoor is dat dergelijke bureaus relatief duur zijn voor kleine bedrijven, omdat zij niet zo vaak een vacature hebben. Daarentegen zal het voor grote bedrijven lonender zijn om via een personeelsfunctionaris de werving zelf ter 
hand te nemen, aangezien zij vaker moeten werven waardoor een interne functionaris rendabel wordt. De bedrijven van 50-IOO medewerkers vallen een beetje tussen wal en schip: niet vaak genoeg een vacature om er intern iemand op te specialiseren, maar vaak genoeg om er in te investeren. Het inhuren van een bureau kan dan de optimale oplossing zijn. Wel blijkt uit nader onderzoek dat bedrijven die een beroep doen op uitzend- en wervingsbureaus, gemiddeld korter openstaande vacatures hebben dan bedrijven die dit wervingskanaal niet gebruiken.

\section{Figuur 3.16}

Aanpassingen in werving en selectie in verband met moeilijk vervulbare vacatures voor technisch personeel en de effectiviteit ervan, 2007-2008 (\% bedrijven)

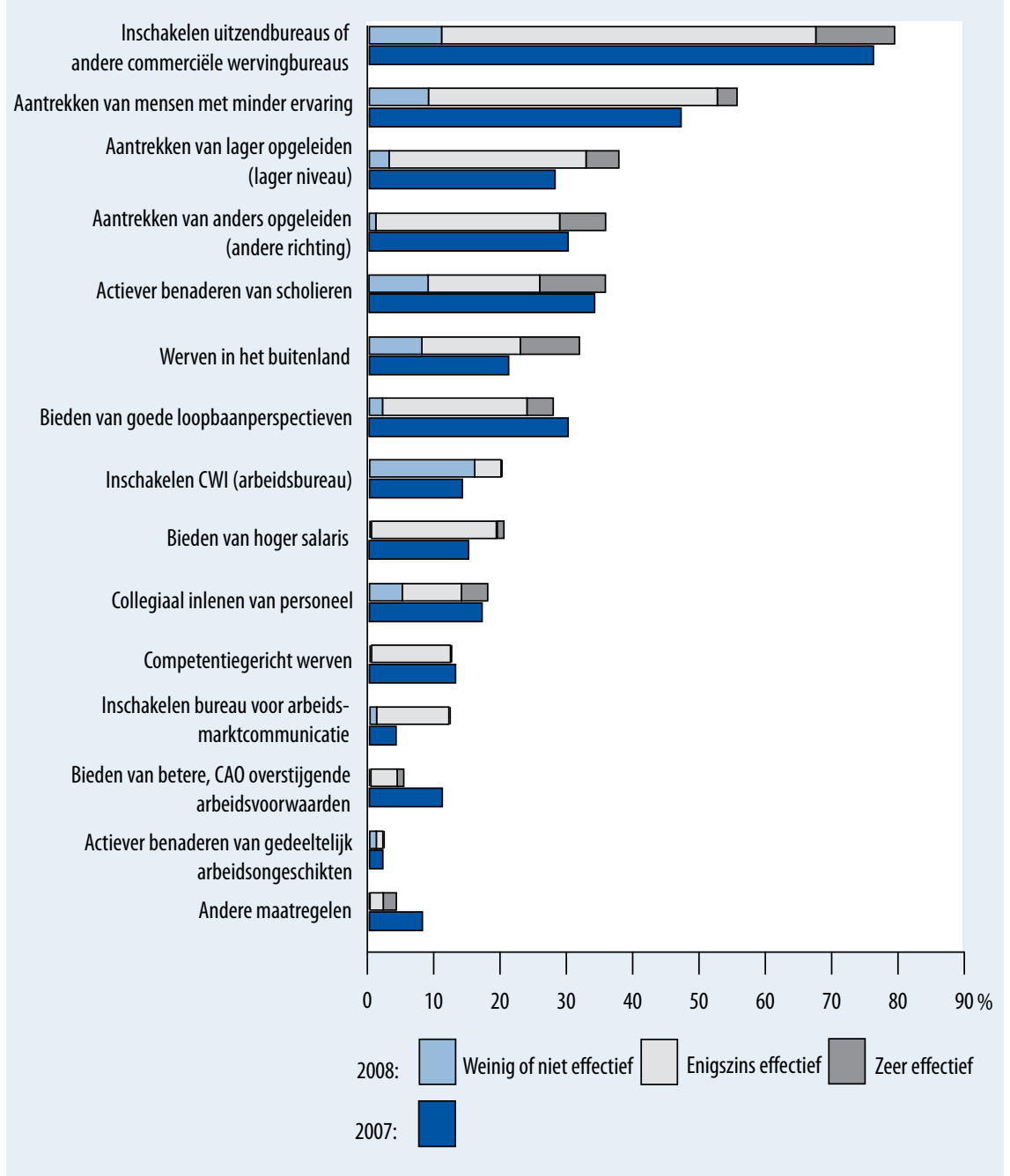

Bron: ROA / Werkgeverspanel Metalektro 
Andere veelgebruikte maatregelen om moeilijk vervulbare vacatures ingevuld te krijgen komen er op neer dat bedrijven niet meer zoeken naar het spreekwoordelijke "schaap met vijf poten", maar genoegen nemen met "een pootje minder". Ze trekken bijvoorbeeld mensen met minder ervaring aan $(56 \%)$, of mensen met een lagere $(37 \%)$ of een andere opleiding $(36 \%)$ dan men aanvankelijk voor ogen had. Ook is eenzelfde percentage bedrijven actiever geworden in het benaderen van scholieren. Deze bevindingen komen overeen met de reacties op de stelling "De arbeidsmarkt wordt zo krap dat wij meer gaan investeren in het aantrekken van voortijdige schoolverlaters, werkzoekenden en zij-instromers" uit één van de Quickscans. Ruim een derde van de bedrijven is het eens met deze stelling. De meeste bedrijven die genoegen nemen met een kandidaat die niet perfect in het totaalplaatje past qua opleidingsniveau, ervaring of opleidingsrichting blijken dit ook effectief te vinden (gemiddeld ongeveer $80 \%)$. Van de bedrijven die scholieren actiever benaderen vindt ruim een kwart deze maatregel zeef effectief en bijna de helft enigszins effectief. De effectiviteit van deze maatregelen verklaart wellicht waarom ze in 2008 door relatief meer bedrijven worden gebruikt dan in 2007.

Verder heeft een aantal bedrijven de hoop op het buitenland gevestigd: $32 \%$ van de bedrijven werft in 2008 in het buitenland en dat is beduidend meer dan in 2007 (2I\%). Ruim een kwart van de bedrijven vindt deze manier van werven zeer effectief en nog eens $46 \%$ van de bedrijven vindt het enigszins effectief. Daarnaast hoopt ruim een kwart van de bedrijven door het bieden van goede loopbaanperspectieven de juiste mensen aan te trekken. Opvallend is dat I op de 5 bedrijven het CWI inschakelt, maar dat $8 \mathrm{I} \%$ van deze bedrijven dit weinig of niet effectief vindt.

Naast andere manieren van werven, passen bedrijven ook hun organisatie aan om op die manier de negatieve gevolgen van moeilijk vervulbare vacatures te verkleinen (zie figuur 3.17). Net als in de voorgaande drie jaar laat ongeveer twee derde van de bedrijven het personeel overwerken. Overwerk wordt in het noorden en oosten van het land vaker ingezet $(85 \%)$ dan in het westen $(63 \%)$ of zuiden van het land $(57 \%)$. Een derde van de bedrijven die hun personeel lieten overwerken vond dit zeer effectief. Vrijwel alle andere bedrijven vonden het enigszins effectief (60\%). Ook het flexibel inzetten van het personeel wordt in 2008 door twee derde van de bedrijven toegepast. Deze maatregel is daarmee in populariteit gegroeid ten opzichte van 2007, toen bijna de helft van de bedrijven de problemen met moeilijk vervulbare vacatures opving door het eigen personeel flexibel in te zetten. ongeveer $60 \%$ van de gebruikers als enigszins effectief en door een derde van de gebruikers als zeer effectief beoordeeld.

Andere interne aanpassingen om moeilijk vervulbare vacatures op te vragen zijn het omscholen of bijscholen van het personeel: $59 \%$ van de bedrijven doet dit tegenover $50 \%$ het jaar ervoor. Daarnaast besloot een aanzienlijk deel van de bedrijven om werk uit te besteden: $43 \%$ doet dit binnen Nederland en $24 \%$ buiten Nederland. Opvallend is dat de bedrijven die werk aan het buitenland hebben uitbesteed dit vaker als zeer effectief beoordelen dan bedrijven die werk binnen Nederland hebben uitbesteed. 
Figuur 3.17

Interne aanpassingen in verband met moeilijk vervulbare vacatures voor technisch personeel en de effectiviteit van deze aanpassingen, 2008 (\% bedrijven)

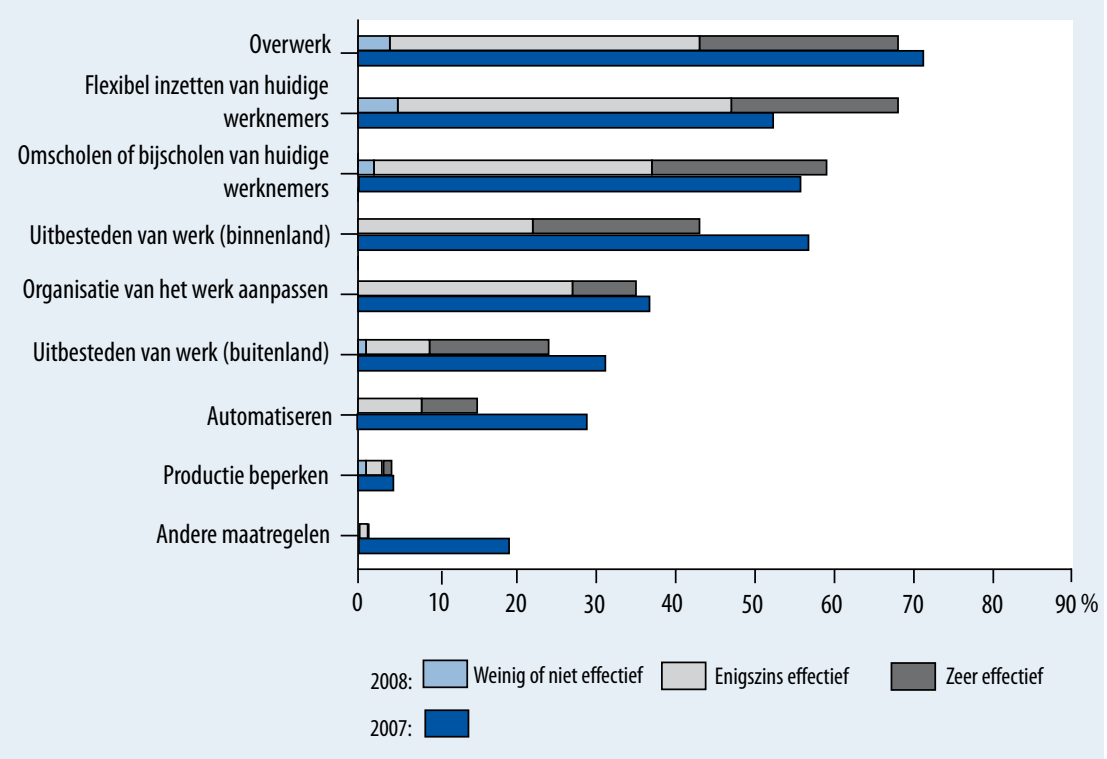

Bron: ROA / Werkgeverspanel Metalektro

Kort samengevat zijn de geschetste wervingsproblemen het grootst wanneer bedrijven zoeken naar personeel voor uitvoerende en ondersteunende technische functies. Het probleem is hier dat er zich te weinig sollicitanten aanbieden en dat sollicitanten lang niet altijd de gewenste competenties of werkervaring bezitten. Metalektrobedrijven pakken deze problematiek onder andere aan door externe hulp in te schakelen of genoegen te nemen met een iets minder perfecte kandidaat. Ook werkt bij veel bedrijven het aanwezige personeel over en wordt het flexibeler ingezet om de negatieve gevolgen van de niet opgevulde functies te beperken. Hierbij moet wel de kanttekening geplaatst worden dat de vragen over de wervingsproblematiek gesteld zijn in de zomer van 2008 nog voor de crisis zich aandiende. Het valt daarom te verwachten dat de problematiek zoals die hier is geschetst eind 2008 minder ernstig is. Echter, in paragraaf 3.2 is al aan de orde gekomen dat metalektrobedrijven eind 2008 nog steeds vacatures hebben en dat deze relatief lang open staan. Het is dus van belang dat ook in de huidige recessie de aandacht voor de wervingsproblematiek bij veel bedrijven niet verslapt. 



\section{Loopbaanmanagement}

Loopbaanmanagement, oftewel het ontwikkelen van medewerkers, staat centraal in dit hoofdstuk. In de eerste paragraaf wordt ingegaan op wat loopbaanmanagement inhoudt en waarom het noodzakelijk is voor bedrijven in de Metalektro. In de daarop volgende paragraaf wordt nagegaan op welke manier metalektrobedrijven vaststellen wat het huidige en het gewenste competentieniveau van hun medewerkers is. Vervolgens wordt beschreven hoe werknemers in de Metalektro zich ontwikkelen door het volgen van scholing (paragraaf 4.3) en interne mobiliteit (paragraaf 4.4). Ter afsluiting geeft paragraaf 4.5 een overzicht van de ontwikkelingen in het loopbaanmanagement van de metalektrobedrijven in de afgelopen jaren en de verwachte ontwikkeling in de nabije toekomst.

\subsection{Waarom loopbaanmanagement in de Metalektro?}

Wanneer het ontwikkelen van medewerkers planmatig wordt aangepakt, wordt gesproken over loopbaanmanagement. Het continu ontwikkelen van medewerkers is in de Metalektro van groot belang gelet op de in dit rapport geschetste ontwikkelingen. Zo is de Metalektro een innovatieve branche waarin bedrijven met grote regelmaat innoveren zowel op technologisch als op sociaal/organisatorisch gebied (zie hoofdstuk I en 5). Om te kunnen innoveren is het van belang dat de medewerkers voldoende kunnen en kennen. Ook is de ontwikkeling van een breed scala aan competenties bij medewerkers vaak gewenst om hun inzetbaarheid te verbreden. Breed inzetbare medewerkers zijn van groot belang voor de flexibiliteit van de onderneming wanneer deze bijvoorbeeld personeelstekorten moet opvangen (zie hoofdstuk 3). Bovendien geven diverse metalektrobedrijven aan dat medewerkers vertrekken als er onvoldoende loopbaanperspectief wordt geboden of als men inhoudelijk op het werk is uitgekeken en toe is aan een nieuwe uitdaging elders als deze niet binnen het bedrijf te vinden is (zie hoofdstuk 3).

Dit komt nog eens extra tot uitdrukking in de reacties op de Quickscanstelling "Willen we ook in de toekomst competent personeel aan blijven trekken dan moeten we binnen ons bedrijf investeren in loopbaanbeleid." $88 \%$ van de bedrijven is het met deze stelling eens en dat is meer dan in 2006 toen $72 \%$ deze stelling onderschreef. Onder de 'eens'stemmers bevinden zich relatief meer grote dan middelgrote en kleine bedrijven. Dit wordt mogelijk veroorzaakt door het feit dat loopbaantrajecten langer en meer divers worden naarmate bedrijven groter zijn. Innovaties, de behoefte aan brede inzetbaarheid en een goed loopbaanperspectief zorgen er voor dat er steeds moet worden gekeken of 
de bestaande competenties van het personeel nog wel voldoen en zo nee, welke competenties op welke manier ontwikkeld moeten worden. Loopbaanmanagement is dus voor een groot deel van de metelaktrobedrijven van groot belang. Echter, slechts $29 \%$ van de metalektrobedrijven zegt aan loopbaanplanning te doen.

Loopbaanmanagement bestaat doorgaans uit twee hoofdonderdelen. Het eerste hoofdonderdeel bestaat uit het bepalen van het huidige competentieniveau van de medewerkers. Vervolgens stellen werkgever en werknemer samen vast welke competenties (verder) ontwikkeld moeten worden. Beide partijen letten hierbij op de praktische haalbaarheid van de te ontwikkelen competenties en of deze aansluiten bij de organisatiedoelen. Ook wordt in het eerste deel vastgesteld op welke manier wordt gemeten of het gewenste competentieniveau is bereikt. In het tweede hoofdonderdeel stellen werkgever en werknemer samen vast welke concrete acties elk moet ondernemen om het gewenste competentieniveau te bereiken. Beide partijen kunnen hierbij kiezen uit een breed scala van mogelijke acties. In de Metalektro gaat het daarbij met name om scholing en interne mobiliteit.

\subsection{Vaststellen van huidig en gewenst competentieniveau}

Om te bepalen wat een werknemer aan competenties in huis heeft en op welk niveau deze competenties zich bevinden, kunnen bedrijven gebruik maken van de resultaten uit de gevoerde functioneringsgesprekken, beoordelingsgesprekken en EVC (Eerder Verworven Competenties). $86 \%$ van de bedrijven voert functioneringsgesprekken en $76 \%$ voert beoordelingsgesprekken. Daarnaast laat figuur 4.I zien dat II\% van de bedrijven gebruik maakt van EVC.

\section{Figuur 4.1}

HRM instrumenten die kunnen worden gebruikt voor het vaststellen van huidig en gewenst competentieniveau, 2008 (\% bedrijven)

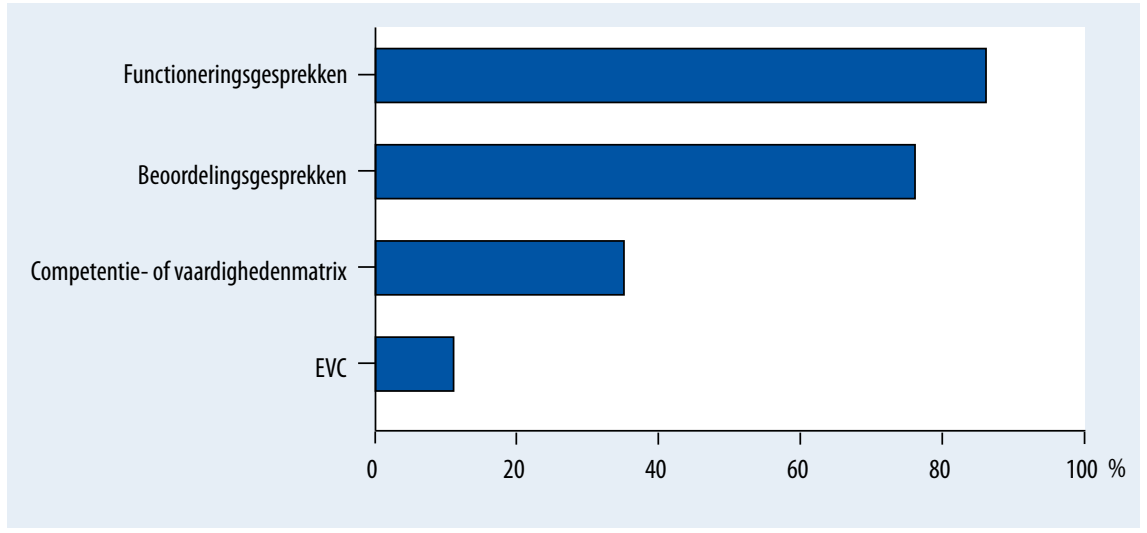

Bron: ROA / Werkgeverspanel Metalektro 
Deze instrumenten zijn ook geschikt om te bepalen wat het gewenste competentieniveau is. Ook de competentie- of vaardighedenmatrix die bij de functie hoort die een werknemer ambieert, kan duidelijk maken welke competenties bijgespijkerd moeten worden. Slechts enkele bedrijven schakelen in deze fase van het loopbaanmanagementproces een externe partij in.

\section{Figuur 4.2}

Wijzigingen in de technische functies in het komende jaar, 2006-2008 (\% bedrijven)

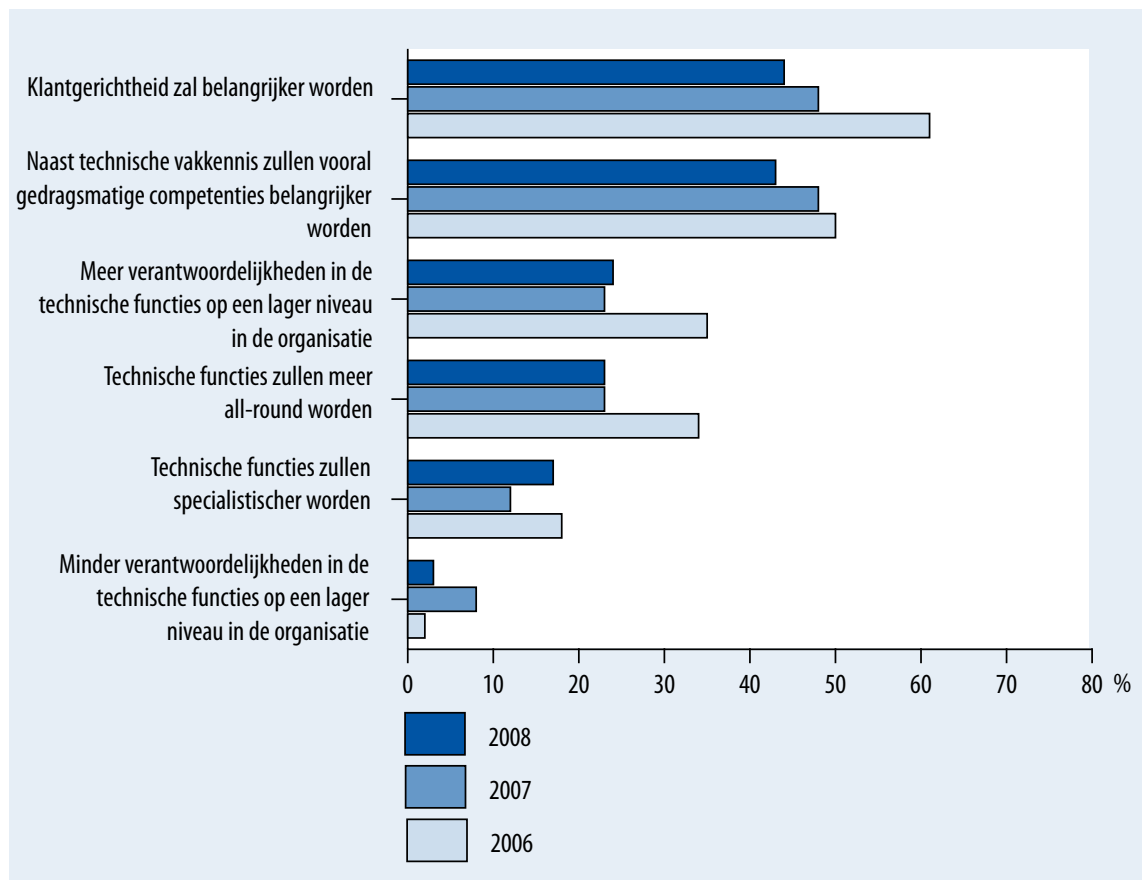

Bron: ROA / Werkgeverspanel Metalektro

Bij het vaststellen van het gewenste competentieniveau houden werkgevers rekening met de eisen die in de nabije toekomst aan de verschillende functies worden gesteld. De inhoud van een functie kan veranderen onder invloed van technologische en sociale innovatie, een behoefte aan brede inzetbaarheid, maar ook omdat de werknemer graag 'iets nieuws' wil. Figuur 4.2 geeft een overzicht van concrete veranderingen in technische functies zoals de werkgevers in de Metalektro die verwachten. Uit dit overzicht blijkt onmiddellijk dat de competentie klantgerichtheid (44\%) en gedragsmatige competenties, zoals probleemoplossend vermogen en initiatief nemen $(43 \%)$, de meest in het oog springende veranderingen zijn. De figuur laat ook zien dat dit al een aantal jaren het geval is. Daarnaast verwacht bijna een kwart van de bedrijven dat technici in 2009 meer verantwoordelijkheden zullen krijgen en dat technische functies meer allround zullen worden. Ook deze verwachtingen geven een duidelijke richting aan de gewenste competenties voor technici. Opmerkelijk is 
overigens dat $17 \%$ van de bedrijven juist denkt dat functies niet meer allround, maar juist specialistischer worden. Vooral de grote (>IOO medewerkers) en middelgrote (5IIoo medewerkers) bedrijven verwachten vaker dat technische functies specialistischer zullen worden.

De verwachte wijzigingen in de technische functies die in figuur 4.2 worden aangegeven, kunnen leiden tot een verschil tussen de gewenste en huidige competenties zowel bij het huidige personeel als bij nieuw aan te trekken personeel, zoals schoolverlaters.

\section{Competentieniveau van schoolverlaters}

In de vorige editie van de Arbeidsmarktmonitor Metalektro is gebleken dat werkgevers vaak niet tevreden zijn over het competentieniveau van de schoolverlaters. Werkgevers vinden dat vooral hun vaktechnische vaardigheden nog tekort schieten, maar ook het probleemoplossend vermogen, zelfstandig werken en communiceren van schoolverlaters haalt niet het door werkgevers gewenste niveau.

Dit maakt het interessant om de vraag te stellen wat de schoolverlaters zelf vinden van hun competentieniveau. Om deze vraag te kunnen beantwoorden is gebruik gemaakt van gegevens uit het SchoolverlatersInformatieSysteem van ROA. Het betreft gegevens van ongeveer I.Ooo personen met een $\mathrm{MBO}$-opleiding werktuigbouw en mechanische techniek en ongeveer I.00o personen met een HBO-opleiding werktuigbouwkunde of elektrotechniek. Al deze personen hebben I,5 jaar na het verlaten van hun opleiding de schoolverlaterenquête ingevuld en waren op dat moment allemaal werkzaam in de Metalektro.

Een meerderheid van de $\mathrm{MBO}$ technici vindt dat zij werken in een functie die qua opleidingsniveau en -richting past bij hun opleiding. Zo werkt driekwart van de $\mathrm{MBO}$-ers in een functie waarvoor de richting werktuigbouw of mechanische techniek of een verwante opleidingsrichting vereist is. Ook geeft $80 \%$ van de $\mathrm{MBO}$-ers aan dat ze werkzaam zijn in een functie waarvoor minimaal een $\mathrm{MBO}$-opleiding vereist is. Verder blijkt dat meer dan de helft van deze MBO-ers vindt dat hun opleiding hen van voldoende kennis en vaardigheden heeft voorzien om goed te kunnen functioneren in hun huidige baan. $62 \%$ van de MBO-ers vindt dat hun kennis en vaardigheden in hun huidige functie voldoende tot in sterke mate worden benut. Hier staat echter wel tegenover dat iets meer dan de helft van de MBO technici vindt dat hun kennis en vaardigheden tekortschieten voor hun huidige functie. Het lijkt er dus op dat over het algemeen $\mathrm{MBO}$ schoolverlaters tevredener zijn over hun competentieniveau dan de werkgevers, maar dat een deel net zoals de werkgevers competentietekorten ervaart.

HBO-ers werken heel vaak in een passende functie: 9 van de Io $\mathrm{HBO}$ schoolverlaters werkt in een functie waarvoor een $\mathrm{HBO}$-diploma in de eigen of verwante studierichting vereist is. $\mathrm{HBO}$-ers zijn over het algemeen tevreden over de bagage die ze van hun opleiding hebben meegekregen: ongeveer twee derde van de HBO-ers vindt hun 
opleiding een goede basis om te starten op de arbeidsmarkt en driekwart vindt dat ze voldoende zijn toegerust om hun kennis en vaardigheden verder te ontwikkelen. De aansluiting tussen de $\mathrm{HBO}$-opleiding en hun werk is volgens de helft van de HBOers voldoende en een kwart beoordeelt deze zelfs als goed. De HBO-ers zijn over het algemeen ook tevreden over hun competentieniveau: 70\% van de $\mathrm{HBO}$-ers ervaart geen competentietekorten. Daar staat tegenover dat bijna de helft van de HBO-ers het gevoel heeft dat hun kennis en kunde (nog) onvoldoende benut worden.

Een vergelijking tussen de schoolverlaters die werkzaam zijn in de Metalektro met een $\mathrm{MBO}$-opleiding en degenen met een $\mathrm{HBO}$-opleiding laat zien dat de $\mathrm{HBO}$-ers iets vaker in een passende functie qua niveau en richting terecht komen en dat ze minder vaak competentietekorten ervaren dan $\mathrm{MBO}$-ers. Daar staat tegenover dat $\mathrm{MBO}$-ers vaker tevreden zijn over de aansluiting tussen hun opleiding en hun werk en dat hun capaciteiten iets vaker voldoende benut worden in hun werk dan bij de HBO-ers. Voor zowel MBO-ers als $\mathrm{HBO}$-ers geldt dat zij over het geheel genomen minder vaak competentietekorten ervaren dan de werkgevers in de Metalektro.

Welke competenties zijn nu eigenlijk belangrijk voor het goed uitoefenen van een functie in de Metalektro? Volgens de MBO-ers zijn dit onder andere vakkennis en het kunnen toepassen van deze kennis in de praktijk (zie figuur 4.3). Meer dan $40 \%$ van de $\mathrm{MBO}$-ers vindt deze competenties zeer belangrijk om hun werk goed te kunnen doen. Andere (meer generieke) competenties die MBO-ers zeer belangrijk vinden, zijn onder andere het oplossen van problemen, het werken in teamverband, zelfstandigheid, initiatief en aanpassingsvermogen. Figuur 4.3 laat hiermee zien dat de competenties die $\mathrm{MBO}$-ers als meest belangrijk ervaren vrijwel naadloos aansluiten op de POFI+ competenties ${ }^{\mathrm{I}}$ die de werkgevers van belang achten.

Ook aan de $\mathrm{HBO}$ schoolverlaters is gevraagd naar de competenties die van belang zijn voor het uitoefenen van hun functie. Tegelijkertijd is hen gevraagd in welke mate zij diverse competenties beheersen. Voor elk van de competenties geldt dat steeds minimaal $40 \%$ tot maximaal $60 \%$ van de HBO-ers aangeeft dat hun eigen niveau gelijk is aan het voor de functie vereiste niveau. Dit betekent dat er bij elke competentie $\mathrm{HBO}-e r s$ zijn die vinden dat hun eigen niveau hoger is dan vereist of dat hun eigen niveau lager is dan voor de functie nodig is. Zo vindt een derde van de $\mathrm{HBO}$-ers dat zij uitstekend in staat zijn om nieuwe dingen te leren en dat ze hun nek durven uit te steken, maar dat deze competenties in veel mindere mate nodig zijn in hun huidige functie. Ook zegt een kwart dat hun ICT-vaardigheden hoger zijn dan voor hun werk nodig is. Een zelfde percentage geeft aan dat zij beter zijn in het ter discussie stellen van ideeën dan op dit moment van hen vereist wordt. Deze bevindingen kunnen verklaren waarom bijna de helft van de $\mathrm{HBO}$-ers heeft aangeven dat hun capaciteiten nog onvoldoende benut worden.

I. De POFI+ competenties zijn probleemoplossend vermogen, omgaan met veranderingen, omgaan met klanten, flexibiliteit en initiatief. 


\section{Figuur 4.3}

Belangrijke competenties voor het uitoefenen van de functie, 1996-2007 (\% MBO schoolverlaters werkzaam in de Metalektro)

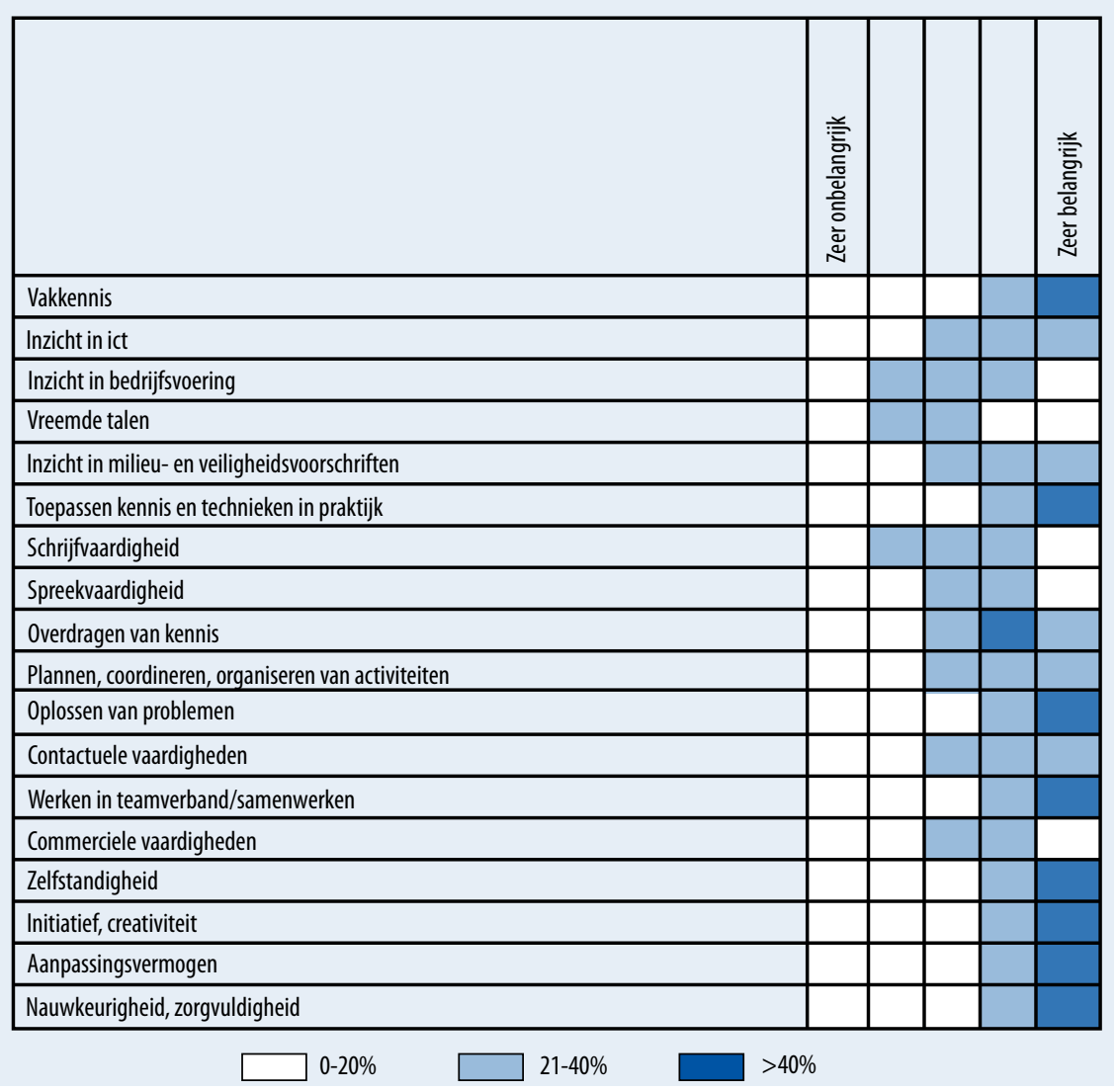

Bron: ROA / SchoolverlatersInformatieSysteem

Naast het hiervoor beschreven surplus aan competentieniveau zijn er ook competenties waarvan een deel van de HBO schoolverlaters die werkzaam zijn in de Metalektro aangeeft dat hun eigen niveau nog onvoldoende is. Hieronder volgt een overzicht van de top 5:

- Iets aan anderen duidelijk kunnen maken (32\%)

- Communiceren in buitenlandse talen $(32 \%)$

- Werken conform budget, planning of richtlijnen (30\%)

- Problemen en kansen signaleren (26\%)

- Goed functioneren onder druk $(24 \%)$

Een en ander laat zien dat een ruime meerderheid van de $\mathrm{HBO}$-ers vindt dat hun competentieniveau overeenkomt met het niveau dat voor hun functie vereist is. Bij de 
meest genoemde competentietekorten bevindt zich geen van de POFI+ competenties. Verder mag men nogmaals concluderen dat de MBO-ers en HBO-ers zelf minder competentietekorten lijken te ervaren dan hun werkgevers aangeven. Dit wijst erop dat veel werkgevers in de Metalektro de competentietekorten die zij bij nieuw aangetrokken schoolverlaters ervaren nog onvoldoende communiceren naar de schoolverlaters zelf. Ook moeten werkgevers de gesignaleerde competentietekorten beter naar de scholen te communiceren.

De competentietekorten die worden gesignaleerd moeten immers worden aangepakt.

Dit geldt overigens ook voor de competentietekorten bij de medewerkers die al langer in dienst zijn. Die aanpak bestaat idealiter uit één of meerder concrete acties die door werknemer en/of werkgever moeten worden ondernomen. Zowel het te bereiken doel (gewenste competentie en niveau) als de acties kunnen worden vastgelegd in het Persoonlijk Opleidingsplan (POP) van de werknemer. 4I\% van de bedrijven maakt op dit moment gebruik van deze POP's. Ook heeft $56 \%$ van de bedrijven een Bedrijfsopleidingsplan (BOP). In de volgende paragraaf worden twee soorten acties besproken waarmee werknemers in de Metalektro hun competentieniveau kunnen verhogen: scholing (paragraaf 4.3) en intern doorstromen naar een andere functie (paragraaf 4.4).

\subsection{Ontwikkeling competenties door scholing}

Scholing wordt door veel bedrijven gezien als één van de belangrijkste instrumenten om de kennis en vaardigheden van medewerkers te verdiepen en te verbreden. Zo biedt $70 \%$ van de bedrijven in de Metalektro opleidingsfaciliteiten en scholingsgesprekken aan.

Als het gaat om de inhoud van de cursussen of opleidingen dan blijken vaktechnische vaardigheden veruit het vaakst gevolgd te worden (zie figuur 4.4). Trainingen met betrekking op het verbeteren of vernieuwen van vaktechnische vaardigheden is, voor 94\% van de bedrijven in de Metalektro, een belangrijke reden om hun technisch personeel bij te scholen.

Op geruime afstand volgt een opleiding in leidinggeven: $45 \%$ van de bedrijven heeft een aantal technici een dergelijke opleiding laten volgen in 2008. Andere opleidingen die relatief vaak worden gevolgd in 2008 zijn gericht op communicatieve vaardigheden $(33 \%)$, taalvaardigheden $(3 \mathrm{I} \%)$, IT $(29 \%)$ en veilig gedrag $(24 \%)$. Het is opmerkelijk dat er in 2008 minder aandacht was voor scholing gericht op communicatieve vaardigheden dan in 2007. In dat jaar volgden medewerkers nog in de helft van de bedrijven opleidingen communicatieve vaardigheden. 


\section{Figuur 4.4}

Inhoud van de gevolgde trainingen en cursussen, 2008 (\% bedrijven)

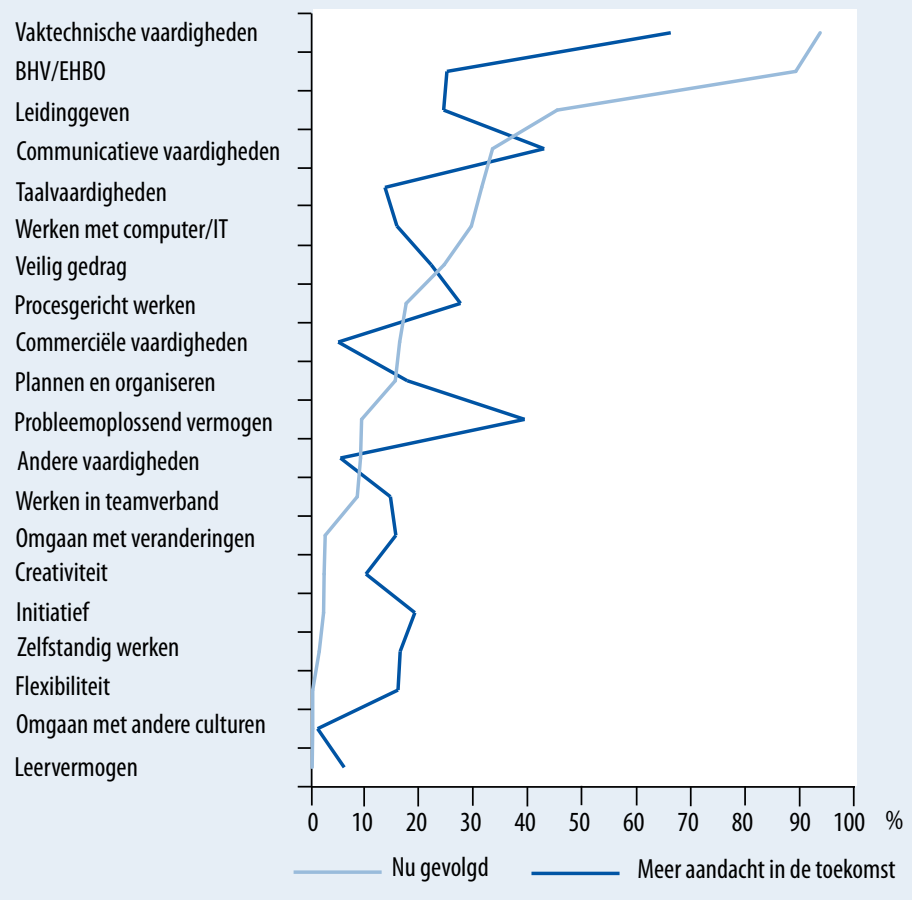

Bron: ROA / Werkgeverspanel Metalektro

De opleidingen gericht op vaktechnische vaardigheden worden het vaakst genoemd als de opleidingen die in de toekomst meer aandacht moeten krijgen. Dit is in maar liefst $66 \%$ van de metalektrobedrijven het geval. Opleidingen in communicatieve vaardigheden $(43 \%)$ en probleemoplossend vermogen (39\%) zijn andere opleidingen die door relatief veel bedrijven in de toekomst van belang worden geacht. Het percentage bedrijven dat zegt dat probleemoplossend vermogen in toekomstige cursussen meer aandacht zal krijgen, is echter tussen 2007 en 2008 gedaald van 52\% naar $39 \%$. Dit zou kunnen worden verklaard door een stijging van het aantal bedrijven dat zijn mensen een cursus ter verbetering van het probleemoplossend vermogen heeft laten volgen. Echter, in 2007 werd in $21 \%$ van de bedrijven een dergelijke cursus gevolgd en in 2008 slechts in $9 \%$ van de bedrijven. De onderwerpen die in de gevolgde scholing aan bod (zullen) komen, blijken goed aan te sluiten op de competenties die volgens schoolverlaters en werkgevers belangrijk zijn en welke niet altijd voldoende aanwezig bij de schoolverlaters. 


\section{Trainings- en cursusdeelname en bijbehorende kosten}

Blijven de bedrijven in de Metalektro investeren in hun personeel nu de economie verslechterd? Er zijn verschillende afwegingen te maken. Mogelijke voordelen om juist in deze periode van recessie het personeel te scholen zijn: (I) Er is nu genoeg tijd om de werknemers te trainen, zonder dat de productie in gevaar komt. (2) In het geval van werktijdverkorting kan de scholing plaatsvinden zonder dat het bedrijf verletkosten makkt aan de verloren werktijd van werknemers die getraind worden. Nadelig is echter dat in deze economisch slechte periode er minder geld beschikbaar is om werknemers te (laten) trainen, omdat de winstgevendheid van bedrijven sterk onder druk staat.

\section{Figuur 4.5}

Ontwikkeling gemiddelde trainings- en opleidingsdeelname in procenten van het aantal technische medewerkers, 2003-2008

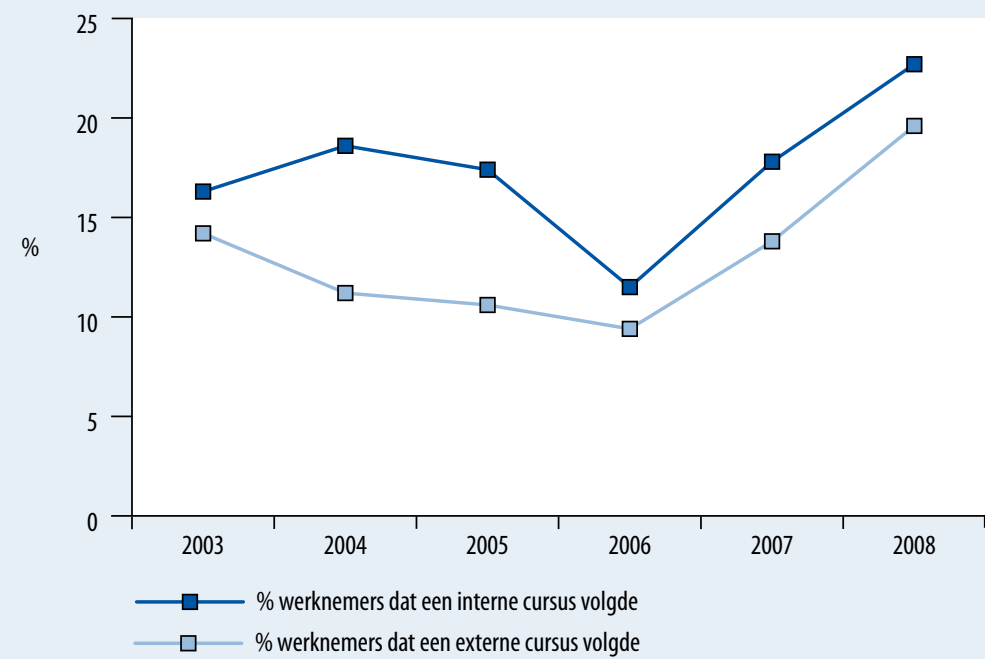

Noot: Sommige technische werknemers kunnen in de afgelopen periode meerdere interne en/of externe cursussen gevolgd hebben, terwijl andere technische werknemers juist geen cursussen volgden. Daarom wordt hier gesproken over de gemiddelde trainingsdeelname.

Bron: ROA / Werkgeverspanel Metalektro

In figuur 4.5 wordt de ontwikkeling van het percentage technische werknemers dat een interne of externe cursus of training heeft gevolgd weergegeven. In deze figuur is te zien dat het percentage technische werknemers dat een externe cursus volgde vanaf 2003 tot 2006 behoorlijk is gedaald van I4 tot $9 \%$. Vanaf 2006 steeg dit percentage echter weer sterk: in 2008 volgde een kleine $20 \%$ van de technische werknemers een externe cursus. Dit is het hoogste percentage sinds dit in de arbeidsmarktmonitor wordt gemeten. De ontwikkeling van het percentage technische werknemers dat intern een cursus volgde, kent een vergelijkbaar verloop, al daalde dit percentage pas 
in 2004. Sinds 2006 zijn er weer steeds meer technische werknemers die een interne cursus gevolgd hebben. In 2008 heeft gemiddeld $23 \%$ van de technische werknemers een interne cursus gevolgd. Dit is net als bij de externe cursussen het hoogste percentage sinds het begin van de monitor.

\section{Figuur 4.6}

Ontwikkeling gemiddelde totale opleidingskosten per bedrijf ( $€$, linkeras) en gemiddeld loonsompercentage (\%, rechteras), 2003-2008

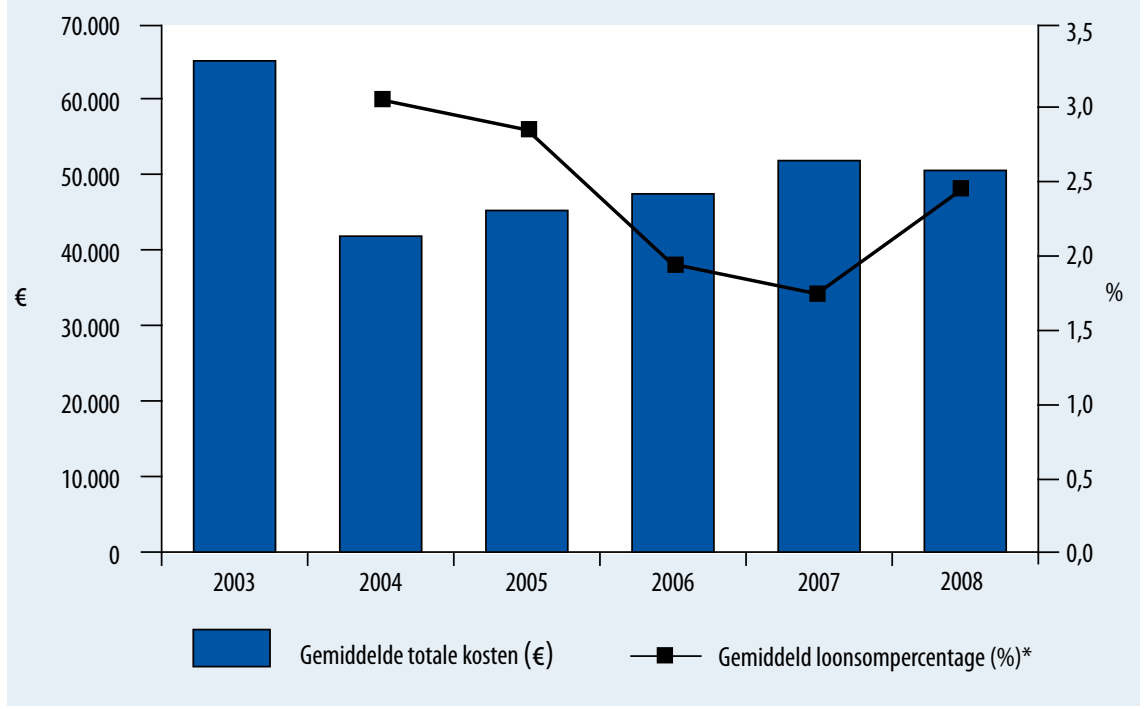

* De totale opleidingskosten als percentage van de loonsom wordt pas sinds 2004 gevraagd, vandaar dat het percentage voor 2003 ontbreekt.

Bron: ROA / Werkgeverspanel Metalektro

In figuur 4.6 wordt de ontwikkeling van twee indicatoren van de opleidingsinspanningen van de metalektrobedrijven weergegeven. Zo wordt in het staafdiagram op de linkeras de gemiddelde totale opleidingskosten per bedrijf weergegeven, terwijl in het lijndiagram op de rechteras het percentage van deze opleidingskosten van de gemiddelde loonsom wordt weergegeven. Overigens moet hierbij worden aangetekend dat deze kosten slechts betrekking hebben op de 'out-of-pocket' kosten, de kosten van de tijd waarin een werknemer wordt opgeleid in plaats van werkt, zijn niet meegenomen.

In 2003 gaven de bedrijven in de Metalektro veruit het meeste uit aan opleidingskosten: gemiddeld ongeveer $€ 65.000$ per bedrijf. Dit is opvallend, aangezien 2003 een recessiejaar was. In 2004 zijn de gemiddelde opleidingskosten fors gedaald, tot $€ 4 \mathrm{I} .800$, In de daaropvolgende jaren steeg dit bedrag echter weer geleidelijk tot $€ 5 \mathrm{I} .800$ in 2007 . In het afgelopen jaar zijn de opleidingskosten voor het eerst sinds 2004 weer gedaald, zij 
het licht: in 2008 gaf een bedrijf in de Metalektro gemiddeld $€ 50.500$ uit. Opvallend genoeg lijkt het gemiddelde loonsompercentage een omgekeerde trend te volgen: in de jaren waarin de gemiddelde kosten stegen, daalde het gemiddelde loonsompercentage. Vooral tussen 2005 en 2006 daalde dit gemiddelde loonsompercentage fors: van $2,8 \%$ naar I,9\%. In 2008 bedroeg het gemiddelde loonsompercentage weer $2,4 \%$. De omgekeerde ontwikkeling van beide indicatoren van opleidingskosten geven wel aan hoe scheef de opleidingskosten tussen de bedrijven verdeeld zijn.

Hoe zit het met de gemiddelde opleidingskosten per werknemer? In 2008 bedroegen de gemiddelde opleidingskosten per werknemer $€$ I.I55. Dit is bijna een halvering ten opzichte van 2007. Toen werd er nog gemiddeld $€ 2.000$ per werknemer besteed. Ook het gemiddeld aantal trainingsdagen per werknemer is in 2008 afgenomen. In 2007 besteedden werknemers gemiddeld nog 9 dagen per jaar aan trainingen en/of cursussen. In 2008 is dit aantal afgenomen tot gemiddeld 6 dagen per jaar.

Het lijkt er dus op dat er ten opzichte van 2007 meer technische werknemers getraind worden, maar dat deze trainingen in 2008 wel minder tijd en geld gekost hebben dan in 2007. Mogelijk zijn dit al gevolgen van de crisis: er is meer tijd, maar minder geld om te trainen, dus meer werknemers worden op cursus gestuurd, maar dit mag minder kosten dan in de afgelopen jaren.

\section{Belemmeringen die bedrijven ervaren bij opleiden}

Wat zijn de redenen waarom technische werknemers bij bedrijven minder of niet opgeleid worden? Figuur 4.7 laat zien wat voor de bedrijven in de Metalektro de belangrijkste belemmerende factoren zijn bij het opleiden. Uit deze figuur blijkt dat meer dan de helft van de bedrijven in 2008 belemmeringen bij het opleiden of trainen van hun technisch personeel ondervindt. $57 \%$ van de bedrijven noemt minstens één belemmering. Dit is ongeveer evenveel als in 2007.

Het feit dat cursussen veel tijd (27\%) en geld (25\%) kosten wordt het vaakst als belemmering genoemd. Geld is in 2008 bij veel meer bedrijven een belemmering voor opleidingsactiviteiten dan in 2007. In 2007 gaf nog slechts $9 \%$ van de bedrijven aan dat geld een belemmering vormde bij het opleiden van het technisch personeel. Andere vaak genoemde belemmeringen zijn: de beschikbare cursussen sluiten niet aan op de behoefte van het bedrijf ( $17 \%)$, cursussen vinden plaats op ongunstige tijdstippen ( $16 \%)$, het technisch personeel is niet geïnteresseerd in cursussen (I2\%) en het verschil tussen de dagelijkse praktijk van het werk en wat in cursussen geleerd wordt, is te groot (II\%). 
Figuur 4.7

Belemmeringen voor de deelname aan trainingen of opleidingen, 2008 (\% bedrijven)

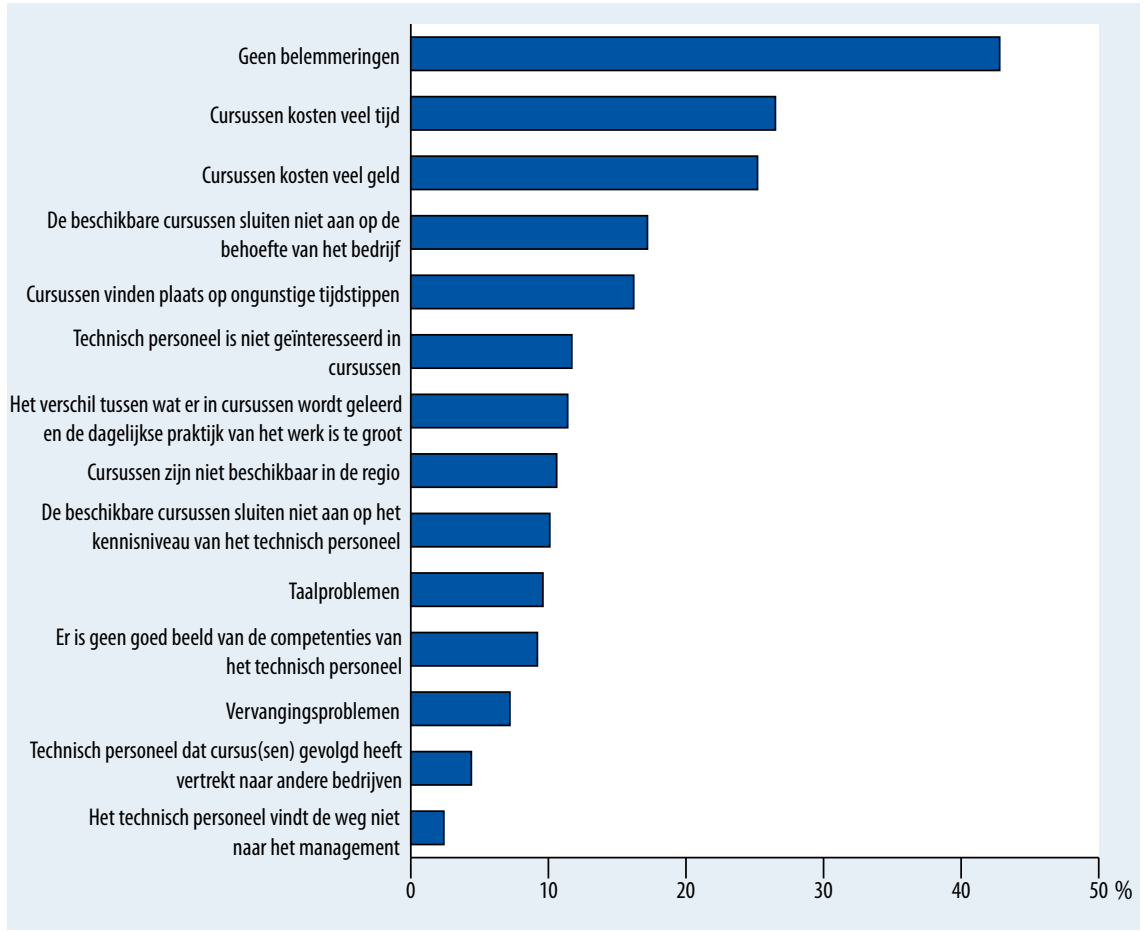

Bron: ROA / Werkgeverspanel Metalektro

\section{Stimuleren van opleiden door bedrijven}

Het is voor veel werkgevers en werknemers in de Metalektro van belang dat men zich niet zomaar neerlegt bij de hiervoor besproken belemmeringen om hun personeel te scholen. Niet scholen leidt tot stilstand of achteruitgang in de ontwikkeling van werknemers waardoor werknemers op een gegeven moment niet meer optimaal inzetbaar zijn. Dit geldt eens te meer voor bedrijven die te maken hebben met veranderingen in productieprocessen of hun organisatie die elkaar in rap tempo kunnen opvolgen. Zo is bijna $40 \%$ van de metalektrobedrijven het eens met de stelling "De technologische ontwikkelingen in ons bedrijf gaan zo snel dat werknemers die niet opgeleid willen worden moeilijker inzetbaar worden”. Daarnaast reageert $29 \%$ neutraal op deze stelling en is $32 \%$ het niet eens met deze stelling.

Hoe proberen de bedrijven in de Metalektro hun technisch personeel te stimuleren om cursussen of trainingen te gaan volgen? Dit is van groot belang, zeker bij werknemers die niet geschoold willen worden, omdat ze er het nut niet van in zien. Deze werknemers kunnen er bijvoorbeeld op gewezen worden welke voordelen er voor hen persoonlijk aan opleiden kunnen zitten, bijvoorbeeld meer uitdagingen/afwisseling in 
het werk, werkzekerheid, of eventueel zelfs een hogere functieschaal of een extra periodiek. Ook is het mogelijk dat werknemers wel geschoold willen worden, maar dat zij niet weten welke mogelijkheden hun bedrijf hiertoe biedt. In dat geval is het noodzakelijk om werknemers beter over de ontwikkelmogelijkheden binnen het bedrijf voor te lichten. Figuur 4.8 geeft antwoord op de vraag hoe de bedrijven in de Metalektro hun werknemers stimuleren om mee te doen aan opleidingsactiviteiten.

\section{Figuur 4.8}

Manieren waarop bedrijven de deelname aan opleidingsactiviteiten van technische werknemers proberen te stimuleren, 2008 (\% bedrijven)

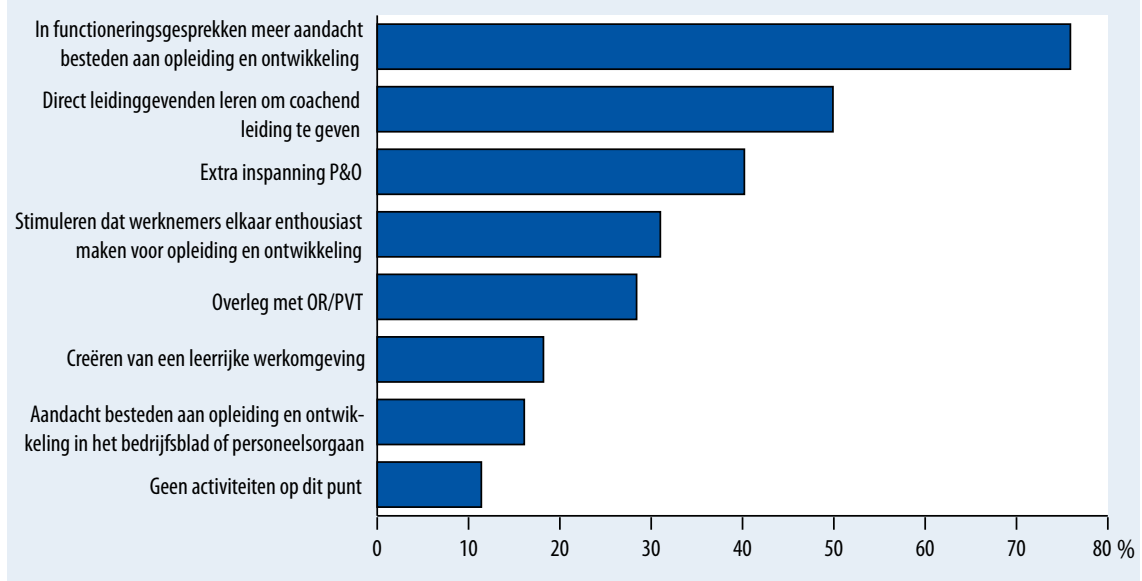

Bron: ROA / Werkgeverspanel Metalektro

Het grootste deel van de bedrijven probeert de deelname aan opleidingsactiviteiten te stimuleren door in functioneringsgesprekken meer aandacht te besteden aan iemands opleiding en ontwikkeling. Maar liefst $76 \%$ van de bedrijven doet dit. Dit is ongeveer even veel als in 2007. De helft van de bedrijven wil de deelname stimuleren door leidinggevenden te leren om coachend leiding te geven. Bij vier op de tien bedrijven probeert de afdeling Personeel \& Organisatie de scholingsdeelname van het technisch personeel te stimuleren door zich hiervoor extra in te spannen. Bij bijna een derde van de bedrijven probeert men te stimuleren dat werknemers elkaar enthousiast maken voor opleiding en ontwikkeling. Slechts II\% van de bedrijven zegt niets te ondernemen om hun werknemers te stimuleren om opleidingsactiviteiten te volgen. 


\section{Rendement van opleiden}

Opleiden is een investering van geld, tijd en energie. Het is daarom van belang om te weten of deze investering het verwachte rendement ook oplevert. Het komt regelmatig voor dat aan het einde van een training of cursus wordt geëvalueerd wat de deelnemers er van vonden, of de training of cursus bijvoorbeeld aan de verwachtingen heeft voldaan. Echter, het nut van een dergelijk training of cursus blijkt doorgaans pas wanneer de werknemer terugkeert op de werkvloer. Sommige bedrijven meten om die reden enkele maanden na de opleiding wat volgens de werknemer en de leidinggevende het rendement is van de gevolgde opleiding.

\subsection{Ontwikkeling competenties door interne mobiliteit}

Naast scholing is het intern doorstromen naar een andere functie (ook wel interne mobiliteit genoemd) een uitstekende manier om nieuwe competenties te verwerven of bestaande competenties te verbeteren. Dit geldt vooral voor competenties die het beste 'on the job' geleerd kunnen worden. Denk hierbij aan competenties zoals probleemoplossend vermogen, initiatief nemen en klantgerichtheid.

\section{Figuur 4.9}

Interne mobiliteit van het technisch personeel, 2005-2008 (\% bedrijven)

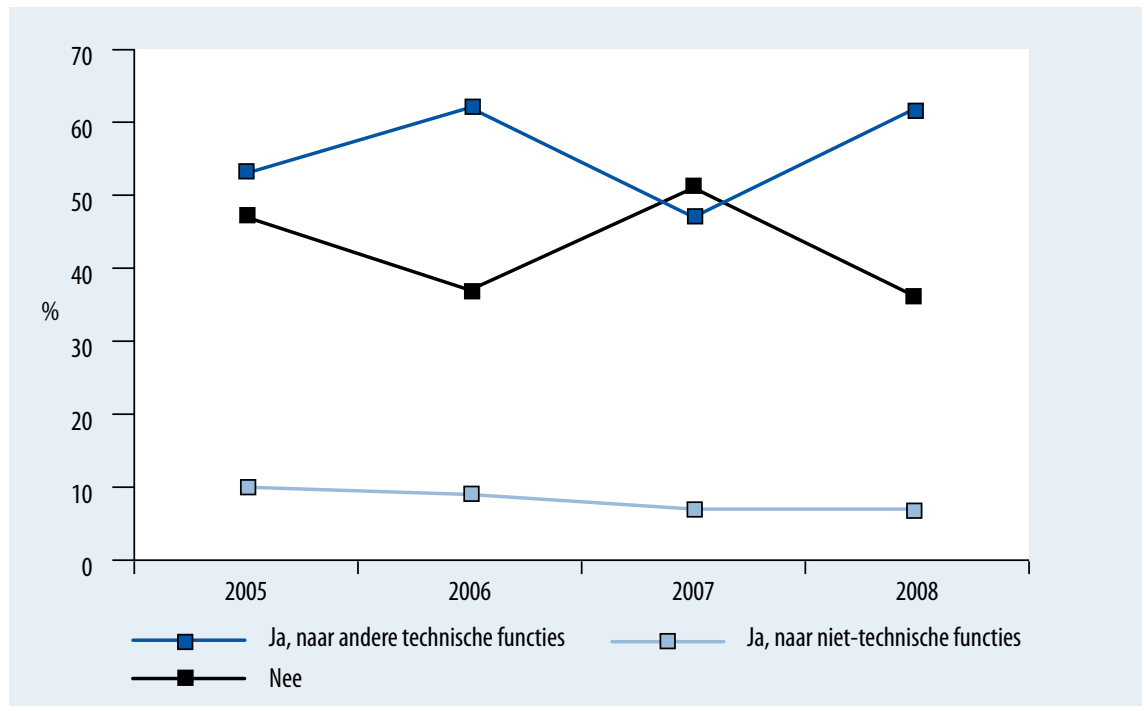

Bron: ROA / Werkgeverspanel Metalektro

Het technisch personeel in de Metalektro stroomt intern vooral door naar andere technische functies: in 2008 stroomt bij $62 \%$ van de metalektrobedrijven technisch personeel door naar een andere technische functie (figuur 4.9). Daarentegen stappen er slechts bij $7 \%$ van de bedrijven technici over naar niet-technische functies. In figuur 
4.9 is ook te zien dat het verschil in doorstroom naar technische versus niet-technische functies al enkele jaren bestaat. Dit verschil wordt waarschijnlijk versterkt door het tekort aan technisch personeel dat groter is dan het tekort aan niet-technisch personeel (zie hoofdstuk 3). Verder geeft een aanzienlijk deel van de bedrijven, variërend tussen de 40 en $50 \%$ in de afgelopen 4 jaar, aan dat er in hun bedrijf geen interne mobiliteit plaatsvindt.

De mobiliteit van het technisch personeel binnen een bedrijf is vaak gekoppeld aan de omvang van het bedrijf. Zo stroomt bij 55\% van de kleinere bedrijven (o-50 medewerkers) en $56 \%$ van de middelgrote bedrijven ( $5 \mathrm{I}-\mathrm{I}$ IOO medewerkers) het technisch personeel intern door. Daarentegen heeft maar liefst $78 \%$ van de grotere bedrijven (>IOO medewerkers) technisch personeel dat binnen het bedrijf doorstroomt naar een andere functie.

\section{Figuur 4.10}

Interne mobiliteit van het technisch personeel naar functieniveau, 2005-2008 (\% bedrijven)

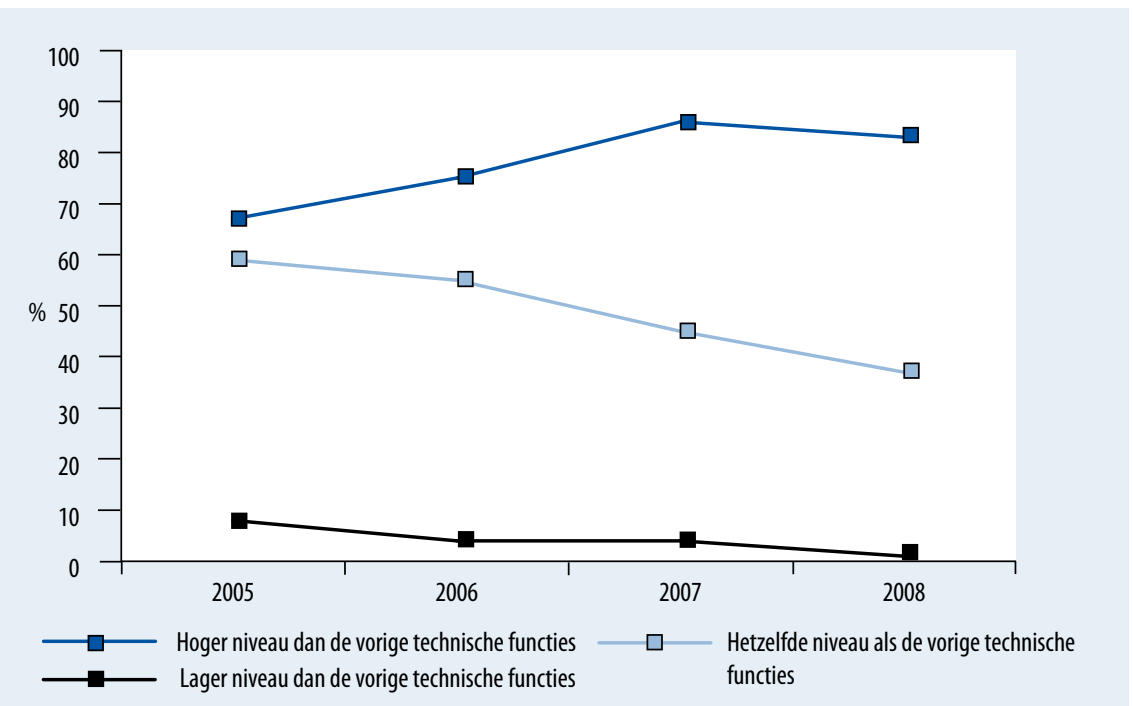

Bron: ROA / Werkgeverspanel Metalektro

De trend van de afgelopen 4 jaar is dat technici bij steeds meer bedrijven naar een hoger functieniveau doorstromen. In 2005 stroomde in $67 \%$ van de bedrijven technici door naar een hogere technische functie en in 2008 is dit maar liefst in $83 \%$ van de bedrijven het geval. Aan de andere kant is het percentage bedrijven dat technici laat doorstromen naar een functie op hetzelfde niveau sterk gedaald: van 59\% in 2005 naar $37 \%$ in 2008 . Technici die doorstromen naar een functie op een hoger niveau zullen waarschijnlijk meer leren dan wanneer zij naar een functie op hetzelfde of een lager niveau zouden zijn doorgestroomd. Het interne mobiliteitsbeleid van de metalektrobedrijven lijkt dus de ontwikkeling van hun technici te stimuleren. Daarnaast laat 
figuur 4.IO zien dat technici in de meeste metalektrobedrijven carrière kunnen maken. Deze carrières ontwikkelen zich zowel in verticale als in horizontale richting.

Over het algemeen zijn de bedrijven in de Metalektro tevreden over de interne doorstroom van hun technisch personeel. Ruim $80 \%$ van de bedrijven heeft zowel in 2008 als in 2007 aangegeven dat de doorstroom van hun technici zich op het gewenste niveau bevindt. In 2006 was dit percentage slechts iets lager: 78\%. De rest van de bedrijven vindt de interne doorstroom van technici aan de lage kant.

Naast het doorstromen naar een andere functie kunnen werknemers hun competenties ook 'on the job' ontwikkelen door functieroulatie. $29 \%$ van de bedrijven past dit HRM instrument toe. Ook geeft 23\% van de bedrijven aan wel eens werknemers uit te wisselen met ander bedrijfsvestigingen. Ook dit biedt mogelijkheden voor werknemers om nieuwe competenties aan te leren of bestaande competenties te verbeteren.

\subsection{Loopbaanmanagementinstrumenten in verleden en toekomst}

In deze paragraaf wordt een beeld gegeven van de ontwikkeling van de HRM instrumenten die de afgelopen 3 jaar voor het loopbaanmanagement zijn ingezet. Ook wordt gekeken naar de verwachte toekomstige ontwikkeling van het loopbaanmanagement. In figuur 4.II is te zien dat loopbaanplanning in 2007 en 2008 door relatief minder bedrijven wordt ingezet dan in het jaar daarvoor.

Het vaststellen van de huidige en gewenste competentieniveaus gebeurde de afgelopen jaren voornamelijk door middel van functioneringsgesprekken (ruim $80 \%$ van de bedrijven) en in de tweede plaats door beoordelingsgesprekken. Deze beoordelingsgesprekken zijn vooral in de afgelopen twee jaar door steeds meer bedrijven gebruikt ( $76 \%$ in 2007 en 2008 tegenover $61 \%$ in 2006). Het gebruik van de competentie- of vaardighedenmatrix ligt al enkele jaren op hetzelfde niveau: rond een derde van de bedrijven makt hiervan gebruik.

De doelen in de vorm van gewenste competenties die werknemers willen bereiken en de bijbehorende concrete acties worden bij relatief meer bedrijven in bedrijfsopleidingsplannen (BOP's) dan in persoonlijke opleidingsplannen (POP's) vastgelegd. Het verschil in het gebruik van POP's en BOP's is in de afgelopen jaren wel steeds groter geworden doordat het gebruik van BOP's harder is gegroeid dan het gebruik van POP's. Bedrijfsopleidingsplannen hebben vooral de laatste twee jaren een behoorlijke vlucht genomen: in 2007 en 2008 heeft ongeveer $55 \%$ van de bedrijven een bedrijfsplan tegenover $44 \%$ in 2006. 
Figuur 4.11

Ontwikkeling HRM/loopbaanmangementinstrumenten, 2006-2008 (\% bedrijven)

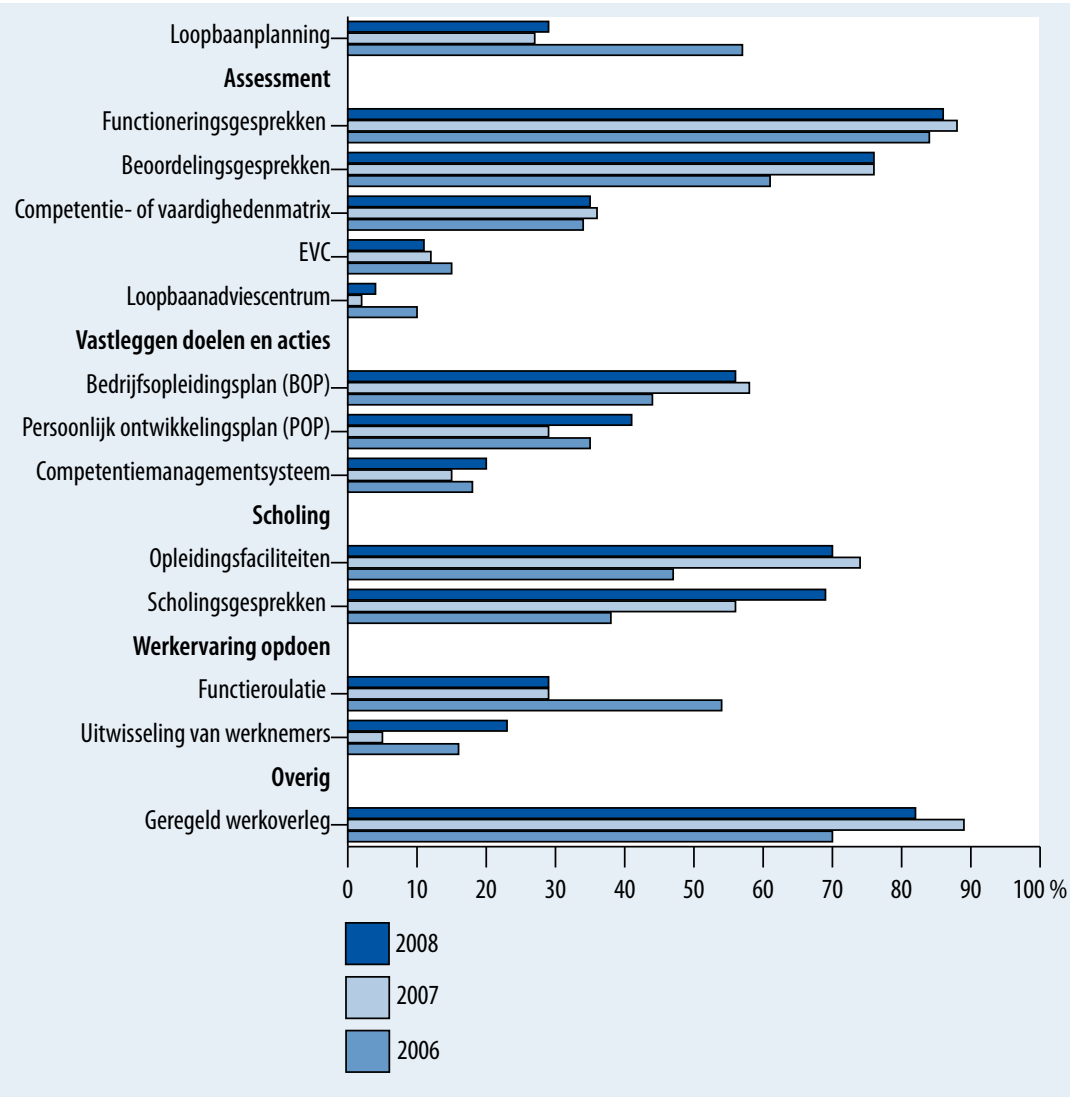

Bron: ROA / Werkgeverspanel Metalektro

Op het terrein van de scholing van het personeel zitten zowel de aangeboden opleidingsfaciliteiten en de scholingsgesprekken aardig in de lift: in 2006 bood $38 \%$ van de bedrijven scholingsgesprekken aan, in 2008 is dit percentage toegenomen tot $69 \%$. Daarentegen zijn bedrijven wat terughoudender geworden in het gebruik van functieroulatie: in 2006 zei $54 \%$ van de bedrijven aan functieroulatie te doen, in 2007 en 2008 geldt dit slechts nog voor $29 \%$ van de bedrijven.

Figuur 4.II heeft laten zien dat loopbaanmanagement de afgelopen jaren als geheel wellicht wat aan belangstelling verloren heeft, maar dat diverse onderdelen van loopbaanmanagement juist door steeds meer bedrijven gebruikt worden. In de eerste Quickscan van 2008 geeft 20\% van de bedrijven ook aan dat men niet hoeft te investeren in de loopbaan van een werknemer als het bedrijf daar geen direct profijt van heeft. 30\% van de bedrijven heeft hierover geen duidelijke mening, maar de helft van de bedrijven vindt dat werkgevers wel in de loopbaan van hun werknemer moeten 
investeren ook al is de directe winst voor het bedrijf niet meteen duidelijk. Opvallend is dat des te kleiner het bedrijf, des te vaker men vindt dat er niet in een loopbaan hoeft te worden geïnvesteerd wanneer het bedrijf er geen direct profijt van heeft. Dit illustreert de kortere tijdshorizon bij het management van de kleinere bedrijven.

Aan de andere kant zijn behoorlijk wat bedrijven van plan om in de toekomst meer aandacht te besteden aan de loopbaanplanning van hun uitvoerend technische personeel. Uit de tweede Quickscan van 2008 blijkt dat 55\% van de bedrijven dit van plan is. Overigens nemen de intenties om meer aandacht aan de loopbaanplanning van de uitvoerende technici te gaan besteden weer toe naarmate het bedrijf groter is.

In de toekomst verwachten de bedrijven meer aandacht te hebben voor het actief managen van de loopbanen van hun medewerkers: in 2007 zegt $35 \%$ van de metalektrobedrijven in de komende 5 jaar een samenhangend loopbaanbeleid te willen voeren, in 2008 is dit toegenomen tot $39 \%$ van de bedrijven. Een belangrijk onderdeel van het loopbaanbeleid is en blijft het stimuleren van de medewerkers om cursussen te volgen. In 2008 zegt $47 \%$ van de bedrijven dat zij in de komende 5 jaar hun medewerkers nog meer wil stimuleren om cursussen te volgen. 


\section{Sociale innovatie}

Innovatie beperkt zich niet tot technologische innovaties alleen. Steeds vaker plegen bedrijven in de Metalektro innovaties op andere gebieden die vaak wel ondersteunend zijn aan technologische innovaties, maar duidelijk van een andere orde zijn. In dat geval wordt gesproken over sociale innovatie. In de eerste paragraaf wordt het onderwerp sociale innovatie nader afgebakend. Vervolgens komen in de daaropvolgende paragrafen de volgende terreinen van sociale innovatie aan bod: organisatie en management (paragraaf 5.2), benutting en ontwikkeling van menselijk kapitaal (paragraaf 5.3) en externe samenwerking (paragraaf 5.4). Tot slot wordt in paragraaf 5.5 ingegaan de factoren die sociale innovatie stimuleren of belemmeren.

\subsection{Sociale innovatie: wat en waarom?}

Sociale innovatie is een breed begrip dat in korte tijd diverse invullingen heeft gekregen. In dit hoofdstuk wordt uitgegaan van de invulling die de Taskforce Sociale Innovatie aan het begrip heeft gegeven: "vernieuwing van de arbeidsorganisatie en het maximaal benutten van competenties gericht op het verbeteren van bedrijfsprestaties en ontplooiing van talent". ${ }^{.}$Maar wanneer kan men spreken over een 'vernieuwing'? Van vernieuwing is sprake als een aanpak wordt gebruikt die nieuw is voor het eigen bedrijf óf wanneer het een reeds gebruikte aanpak betreft die significant verbeterd is. ${ }^{2}$ Tot slot is van belang dat het gaat om veranderingen die daadwerkelijk hebben plaats gevonden. Een plan tot sociale innovatie is op zichzelf nog geen sociale innovatie.

Waarom een bedrijf aan sociale innovatie zou moeten doen, volgt voor een deel al uit bovenstaande definitie. Het moet leiden tot betere bedrijfsprestaties en het ontplooien van het talent van de medewerkers. Betere bedrijfsprestaties worden hier geoperationaliseerd als (I) een hogere productiviteit per werknemer, (2) kwaliteitsverbetering van de producten en (3) flexibilisering van de productie. Het ontplooien van de medewerkers wordt onder andere geconcretiseerd door (I) het bieden van kwalitatief hoogwaardige werkgelegenheid en (2) als werkgever aantrekkelijker worden. Over het geheel genomen lijken bedrijven in de Metalektro zich met name te richten op vormen van sociale innovatie waarmee de arbeidsproductiviteit kan worden verhoogd

I. Taskforce Sociale Innovatie (2005), Sociale innovatie, de Andere Dimensie, Eindrapport, Den Haag.

2. OECD (2005), Oslo Manual: Guidelines for Collecting and Interpreting Innovation Data, Parijs. 
of waardoor de productie flexibeler wordt. Per innovatievorm zijn er echter verschillen in welk doel er wordt nagestreefd (zie paragraaf 5.2).

Sociale innovatie is een verzameling van allerhande veranderingen. Grofweg is deze verzameling in te delen in drie categorieën:

I. Organisatie en management: innovaties die vooral betrekking hebben op de manier waar op het werk en de verantwoordelijkheden worden georganiseerd en hoe het bedrijf door het management wordt geleid.

2. Het menselijk kapitaal van het bedrijf: innovaties waardoor het menselijk kapitaal beter kan worden benut binnen het bedrijf en innovaties waardoor dit kapitaal verder ontwikkeld kan worden.

3. Nieuwe vormen van samenwerking in de bedrijfsomgeving: allianties met andere bedrijven, samenwerking met leveranciers, klanten en kennisorganisaties.

In de komende drie paragrafen zullen deze drie soorten van sociale innovatie worden besproken zoals ze binnen de Metalektro plaats vinden. ${ }^{3}$

\subsection{Organisatie en management}

Vrijwel alle bedrijven in de Metalektro hebben een vorm van sociale innovatie op de agenda staan. 95\% van de metalektrobedrijven geeft aan dat ze in 2008 sociale innovatie hebben doorgevoerd óf dit zullen doen in het komende jaar óf in de komende 5 jaar. Ook in 2007 stond sociale innovatie op die manier bij vrijwel alle bedrijven op de agenda (97\%). Plannen alleen maken echter nog geen sociale innovatie, veel staat of valt met de daadwerkelijke uitvoering. $82 \%$ van de bedrijven in de Metalektro heeft een vorm van sociale innovatie al uitgevoerd of doet dat in het komende jaar. Ook dit percentage is stabiel ten opzichte van vorig jaar: $83 \%$.

Deze percentages hebben overigens allen betrekking op de innovaties die onder de categorie "organisatie en management" vallen. Maar over wat voor innovaties gaat het dan precies? In figuur 5.I is te zien dat, zowel in 2007 als in 2008, de nadruk vooral ligt op innovaties die gericht zijn op het horizontaal organiseren van het werk (team werk, taakintegratie, projectmatig werken) en op een innovatieve strategie. Daarbij gaat de meeste aandacht uit naar het variabel inzetten van het personeel: driekwart van de bedrijven in de Metalektro zet haar personeel variabel in of gaat dan doen. $49 \%$ heeft deze innovatie al doorgevoerd of doet dat in het komende jaar en nog eens een kwart verwacht dit in de komende 5 jaar te gaan doen.

3. Een vierde vorm van sociale innovatie die in dit rapport verder niet aan bod komt, bestaat uit de manieren waarop bedrijven met overheden en sociale partners samenwerken om de drie eerder genoemde vormen van sociale innovatie te realiseren. 


\section{ISO certificering en ontwikkeling van hulpmiddelen voor op de werkvloer}

Eén van de metalektrobedrijven heeft de ISO certificeringsprocedure aangegrepen om de beschrijving van de processen en eindproducten ook op de werkvloer in te zetten. Op de werkvloer is documentatie voorhanden die foto's van het gewenste eindproduct bevat en beschrijvingen van hoe te handelen bij een bepaalde afwijking. Dit zorgt ervoor dat productiemedewerkers zelf een aantal beslissingen kunnen nemen in geval van afwijkingen zonder hiervoor een 'baas' te hoeven raadplegen. Productieteams worden zo zelfstandiger waardoor problemen veelal sneller kunnen worden opgelost.

Projectmatig werken is een vorm van sociale innovatie die bij maar liefst twee derde van de bedrijven in gebruik is of in de toekomst zal worden gebruikt (zie figuur 5.I). Naast diverse vormen van teamwerk (multifunctionele en zelfsturende teams) blijkt ook uit de figuur dat I op de 5 bedrijven al een innovatiegerichte strategie heeft of die het komende jaar zal formuleren. Nog eens 2 op de 5 bedrijven wil een dergelijke strategie in de komende 5 jaar definiëren. Niet zichtbaar in de figuur is dat slechts een minderheid van de bedrijven veranderingen aanbrengt in de verticale organisatie van het bedrijf: een derde werkt aan het verminderen van het aantal managementlagen, ongeveer $20 \%$ centraliseert verantwoordelijkheden en $20 \%$ van de bedrijven decentraliseert.

\section{Figuur 5.1}

Sociale innovatie: organisatie en management, 2007-2008 (\% bedrijven)

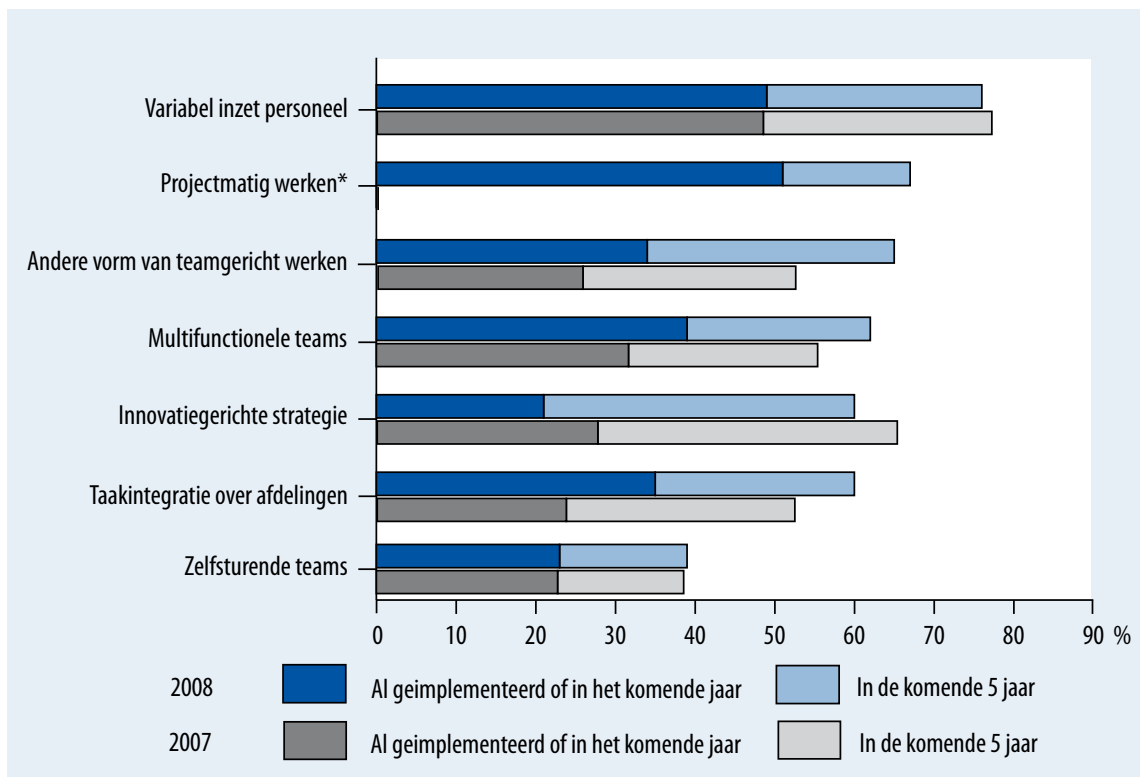

* Projectmatig werken is in 2008 voor het eerst als antwoordoptie toegevoegd, vandaar dat er voor 2007 geen gegevens bekend zijn.

Bron: ROA / Werkgeverspanel Metalektro 
Een vergelijking van deze vormen van sociale innovatie tussen 2007 en 2008 leert dat het (geplande) gebruik van deze innovatievormen tamelijk stabiel is. Dit lijkt er op te wijzen dat de crisis (vooralsnog) geen negatieve invloed heeft op de aandacht voor sociale innovatie op het terrein van organisatie en management. Immers, de vragen over sociale innovatie zijn gesteld in de tweede meting die in januari 2009 plaatsvond. Op dat moment was de ernst van de crisis reeds duidelijk zichtbaar.

\section{Doelstellingen van sociale innovatie op het gebied van organisatie en management}

Aan de bedrijven die aan sociale innovatie op het gebied van organisatie en management doen of voornemens zijn dit te gaan doen, is gevraagd welk(e) doel(en) zij hiermee willen bereiken. Het blijkt dat de nagestreefde doelen voor de organisatorische veranderingen behoorlijk divers zijn én dat bedrijven veelal meerdere doelen nastreven met een en dezelfde organisatorische verandering. Over het algemeen worden de doelstellingen hogere productiviteit per werknemer en kwaliteitsverbetering van de producten iets vaker genoemd dan de doelstellingen kwalitatief hoogwaardige werkgelegenheid, flexibilisering van de productie en als werkgever aantrekkelijker worden. Dit geldt vooral voor de bedrijven die multifunctionele teams, andere vormen van teamgericht werken of een innovatieve strategie (gaan) invoeren.

In figuur 5.2a wordt in beeld gebracht op welke termijn de bedrijven denken het gestelde doel van een organisatorische verandering te realiseren. Daarbij wordt een onderscheid gemaakt tussen: het is al gerealiseerd, het gaat in het komend jaar gebeuren en het doel wordt in de komende 5 jaar gerealiseerd. De figuur kan als volgt worden gelezen: van de bedrijven die hun personeel al in zelfsturende teams laten werken of dit gaan doen, heeft 0-20\% van de bedrijven (wit) het doel hogere productiviteit al bereikt (zie linksonder in de figuur). Meer dan $40 \%$ van de bedrijven (donkerblauw) die hun personeel in zelfsturende teams laten werken, hoopt hiermee in het komende jaar een hogere productiviteit te bereiken. Tot slot verwacht $2 \mathrm{I}-4 \mathrm{O} \%$ van de bedrijven (lichtblauw) die hun personeel in zelfsturende teams laten werken, dat de productiviteit van dit personeel binnen 5 jaar zal toenemen.

Figuur 5.2a laat zien dat de meeste bedrijven de beoogde doelen nog niet bereikt hebben. Dit geldt met name voor de beoogde hogere productiviteit per werknemer. Daarentegen is bij veranderingen die als doel het flexibeler maken van de productie hadden, bij veel bedrijven het doel al gerealiseerd. Een deel van de bedrijven verwacht overigens dat het niet meer zo lang zal duren voordat de andere beoogde doelen van sociale innovatie worden bereikt. Immers, de percentages bedrijven die verwachten hun doelen komend jaar te bereiken zijn voor een aantal veranderingen hoger dan de percentages bedrijven die denken dat ze 5 jaar nodig zullen hebben om het gewenste effect te zien. Dit is met name het geval bij bedrijven die veranderingen met betrekking tot teams, takkintegratie over de afdelingen of een innovatiegerichte strategie doorvoeren. 
Figuur 5.2a

Doelstellingen van sociale innovatie op het gebied van organisatie en management, 2008 (\% bedrijven)

\begin{tabular}{|c|c|c|c|c|c|}
\hline \multirow{2}{*}{$\begin{array}{l}\text { Variabele inzet personeel } \\
\text { Doel al bereikt }\end{array}$} & $\begin{array}{l}\text { Hogere productiviteit } \\
\text { per werknemer }\end{array}$ & $\begin{array}{l}\text { Kwalitatief hoog- } \\
\text { waardige } \\
\text { werkgelegenheid }\end{array}$ & $\begin{array}{l}\text { Kwaliteitsverbetering } \\
\text { van de prodcuten }\end{array}$ & $\begin{array}{l}\text { Flexibilisering } \\
\text { van de productie }\end{array}$ & $\begin{array}{l}\text { Als werkgever } \\
\text { aantrekkelijker } \\
\text { worden }\end{array}$ \\
\hline & \multicolumn{5}{|c|}{ Doel al bereikt } \\
\hline \multirow{2}{*}{\multicolumn{5}{|c|}{$\begin{array}{l}\text { Doel in komend jaar te bereiken } \\
\text { Doel in komende } 5 \text { jaar te bereiken }\end{array}$}} & \\
\hline & & & & & \\
\hline \multicolumn{6}{|l|}{$\begin{array}{l}\text { Doel in Komenae j jaar te berelken } \\
\text { Projectmatig werken }\end{array}$} \\
\hline \\
\hline \multicolumn{6}{|l|}{ Doel in komend jaar te bereiken } \\
\hline \multicolumn{6}{|l|}{ Doel in komende 5 jaar te bereiken } \\
\hline \multicolumn{6}{|l|}{ Andere vorm teamgericht werken } \\
\hline \multicolumn{6}{|l|}{ Doel al bereikt } \\
\hline \multicolumn{6}{|l|}{ Doel in komend jaar te bereiken } \\
\hline \multirow{2}{*}{\multicolumn{6}{|c|}{$\begin{array}{l}\text { Doel in komende } 5 \text { jaar te bereiken } \\
\text { Multifunctionele teams }\end{array}$}} \\
\hline & & & & & \\
\hline \multicolumn{6}{|l|}{ Doel al bereikt } \\
\hline \multicolumn{6}{|l|}{ Doel in komend jaar te bereiken } \\
\hline \multicolumn{6}{|l|}{$\begin{array}{l}\text { Doel in komende } 5 \text { jaar te bereiken } \\
\text { Innovatiegerichte strategie }\end{array}$} \\
\hline Innovatiegerichte strategie & & & & & \\
\hline \multicolumn{6}{|l|}{ Doel al bereikt } \\
\hline \multicolumn{6}{|l|}{ Doel in komend jaar te bereiken } \\
\hline \multicolumn{6}{|l|}{ Doel in komende 5 jaar te bereiken } \\
\hline \multicolumn{6}{|l|}{ Taakintegratie over afdelingen } \\
\hline \\
\hline \multirow{2}{*}{\multicolumn{6}{|c|}{$\begin{array}{l}\text { Doel in komend jaar te bereiken } \\
\text { Doel in komende } 5 \text { jaar te bereiken }\end{array}$}} \\
\hline & & & & & \\
\hline \multicolumn{6}{|l|}{ Zelfsturende teams } \\
\hline \multirow{2}{*}{\multicolumn{6}{|c|}{$\begin{array}{l}\text { Doel al bereikt } \\
\text { Doel in komend jaar te bereiken }\end{array}$}} \\
\hline & & & & & \\
\hline Doel in komende 5 jaar te bereiken & & & & & \\
\hline
\end{tabular}

Bron: ROA / Werkgeverspanel Metalektro

In figuur $5.2 \mathrm{~b}$ worden de nagestreefde doelen per organisatorische verandering in 2007 en 2008 met elkaar vergeleken door de percentages van 2008 met die van 2007 te vergelijken. Figuur 5.2b laat zien dat er in 2008 weinig veranderd is ten opzichte van 2007. Dit mag verrassend genoemd worden. Immers, in 2007 gaven ook vrij grote percentages bedrijven aan dat zij de betreffende verandering doorvoerden om binnen een jaar een bepaald doel te bereiken. Dit zou dan in 2008 hebben moeten leiden tot hogere percentages "doel bereikt" en lagere percentages 'doel in komend jaar te bereiken'. Die ontwikkeling is echter nauwelijks in figuur $5.2 \mathrm{~b}$ terug te vinden.

Er lijkt juist een omgekeerde beweging aan de gang te zijn: ${ }^{4}$ bij een aantal veranderingen geven in 2008 meer bedrijven aan dat ze verwachten hun doelen pas over een

4. Bij deze bevindingen dient wel de kanttekening geplaatst te worden dat bovenstaande vragen in 2007 en in 2008 maar voor een deel door dezelfde bedrijven zijn beantwoord. 
jaar of zelfs pas over vijf jaar te bereiken, dan in 2007. Dit geldt vooral voor de prestatiedoelen op bedrijfsniveau als hogere werknemersproductiviteit, verbeterde kwaliteit van de producten en flexibilisering van de productie. Een uitzondering hierop zijn de zelfsturende teams. Bij deze sociale innovatie nemen de percentages voor de doelen die binnen een jaar bereikt moeten worden toe. Voor de doelen 'kwaliteitsverbetering producten' en 'een aantrekkelijkere werkgever worden' van zelfsturende teams zijn de percentages voor doel al bereikt ook nog eens sterk gestegen tussen 2007 en 2008. Dit wijst er op dat de invoering van zelfsturende teams relatief snel resultaat oplevert.

Figuur 5.2b

Doelstellingen van sociale innovatie op het gebied van organisatie en management, 2007-2008 (\% bedrijven)

\begin{tabular}{|c|c|c|c|c|c|}
\hline \multirow[b]{2}{*}{ Variabele inzet personeel } & $\begin{array}{l}\text { Hogere productiviteit } \\
\text { per werknemer }\end{array}$ & $\begin{array}{l}\text { Kwalitatief hoog- } \\
\text { waardige } \\
\text { werkgelegenheid }\end{array}$ & $\begin{array}{l}\text { Kwaliteitsverbetering } \\
\text { van de prodcuten }\end{array}$ & $\begin{array}{l}\text { Flexibilisering } \\
\text { van de productie }\end{array}$ & $\begin{array}{l}\text { Als werkgever } \\
\text { aantrekkelijker } \\
\text { worden }\end{array}$ \\
\hline \multirow{2}{*}{\multicolumn{6}{|c|}{$\begin{array}{l}\text { Doel al bereikt } \\
\text { Doel in komend jaar te bereiken }\end{array}$}} \\
\hline & & & & & \\
\hline \multicolumn{6}{|l|}{$\begin{array}{l}\text { Doel in komende } 5 \text { jaar te bereiken } \\
\text { D. }\end{array}$} \\
\hline \multirow{2}{*}{\multicolumn{6}{|c|}{ Andere vorm teamgericht werken }} \\
\hline & & & & & \\
\hline \multicolumn{6}{|l|}{$\begin{array}{l}\text { Doel al bereikt } \\
\text { Doel in komend jaar te bereiken }\end{array}$} \\
\hline \multicolumn{6}{|l|}{ Doel in komende 5 jaar te bereiken } \\
\hline \multicolumn{6}{|l|}{ Multifunctionele teams } \\
\hline \multirow{2}{*}{\multicolumn{6}{|c|}{$\begin{array}{l}\text { Doel al bereikt } \\
\text { Doel in komend jaar te bereiken }\end{array}$}} \\
\hline & & & & & \\
\hline \multicolumn{6}{|l|}{ Doel in komende 5 jaar te bereiken } \\
\hline \multicolumn{6}{|l|}{ Innovatiegerichte strategie } \\
\hline \multicolumn{6}{|l|}{ Doel al bereikt } \\
\hline \multicolumn{6}{|l|}{ Doel in komend jaar te bereiken } \\
\hline \multicolumn{6}{|l|}{ Doel in komende 5 jaar te bereiken } \\
\hline \multicolumn{6}{|l|}{ Taakintegratie over afdelingen } \\
\hline \multicolumn{6}{|l|}{ Doel al bereikt } \\
\hline \multicolumn{6}{|l|}{ Doel in komend jaar te bereiken } \\
\hline \multicolumn{6}{|l|}{ Doel in komende 5 jaar te bereiken } \\
\hline \multicolumn{6}{|l|}{ Zelfsturende teams } \\
\hline \multicolumn{6}{|l|}{ Doel al bereikt } \\
\hline \multirow{2}{*}{\multicolumn{6}{|c|}{ Doel in komend jaar te bereiken }} \\
\hline & & & & & \\
\hline & Verschil tus & in de percentage & an 2007 en 2008 is & rocentpunten of & inder \\
\hline & Percentag & 2008 is 6 proc & unten of meer lag & $\operatorname{lan}$ in 2007 & \\
\hline & Percenta & 2008 is 6 proc & unten of meer hoc & dan in 2007 & \\
\hline
\end{tabular}

Bron: ROA / Werkgeverspanel Metalektro

Naast de hiervoor besproken veranderingen verwacht $24 \%$ van de bedrijven dat hun technisch personeel lager in de organisatie meer verantwoordelijkheden zal gaan dragen in het komende jaar. Bijna de helft van de bedrijven verwacht dat dit in de komende 5 jaar zal gebeuren. Daarnaast wil een kwart van de bedrijven in de komende 5 jaar het personeel meer bij het beleid van de organisatie betrekken. In datzelfde tijdsbestek wil I op de 5 bedrijven prestatiebeloning en/of flexibele beloning invoeren, terwijl 2 op de 5 bedrijven in die periode coachend leiderschap wil introduceren. Ook 
deze veranderingen zijn aan te merken als vormen van sociale innovatie op het terrein van organisatie en management.

Wanneer deze genoemde veranderingen door hetzelfde bedrijf worden toegepast kunnen innovaties elkaar versterken: als personeel meer bij het organisatiebeleid betrokken wordt, zullen ze er meer kennis van hebben en kan het organisatiebeleid als referentiekader dienen voor de individuele beslissingen van het personeel. De kans neemt dan toe dat individuele beslissingen in lijn zijn met het organisatiebeleid in plaats van het tegen te werken. Wanneer personeel meer verantwoordelijkheden heeft, is het ook eenvoudiger om hen af te rekenen op het resultaat van hun beslissingen en acties. Technisch personeel lager in de organisatie kan waarschijnlijk ondersteuning gebruiken bij het omgaan met hun nieuwe verantwoordelijkheden. Coachend leiderschap is dan één van de instrumenten die bedrijven kunnen gebruiken om hun personeel te begeleiden bij het omgaan met de (extra) verantwoordelijkheden.

Maar in hoeverre nemen bedrijven die verwachten dat hun technisch personeel meer verantwoordelijkheden zal krijgen ook inderdaad bovenstaande extra maatregelen? $27 \%$ van deze bedrijven is van plan het personeel meer bij het organisatiebeleid te betrekken. 21\% van de bedrijven die verwachten dat hun technisch personeel meer verantwoordelijkheid zal dragen, wil ook prestatie- of flexibele beloning invoeren en $4 \mathrm{I} \%$ is van plan het coachend leiderschap te bevorderen.

\subsection{Benutting en ontwikkeling van menselijk kapitaal}

Sociale innovatie op het gebied van organisatie en management kan doorgaans pas succesvol zijn als de competenties van het personeel deze innovaties ondersteunen. Lang niet iedereen zal direct in staat zijn om optimaal in een team te functioneren of extra verantwoordelijkheden te dragen. Het is dus van belang dat dergelijke innovaties worden vergezeld door maatregelen die er voor zorgen dat het competentieniveau van het personeel past bij de nieuw gestelde eisen. Het ontwikkelen van de vereiste competenties is daarmee ook een belangrijk onderdeel van het sociale innovatiebeleid van een bedrijf. Het inschatten van het huidige en gewenste competentieniveau en de maatregelen die nodig zijn om competenties te ontwikkelen vallen in feite onder loopbaanmanagement en zijn daarom al in hoofdstuk 4 besproken. Bedrijven maken door middel van functioneringsgesprekken en beoordelingsgesprekken een inschatting van het huidige competentieniveau van hun werknemers. Vervolgens komt vaak ook uit deze gesprekken naar voren welke competenties de werknemer moet of wil ontwikkelen, bijvoorbeeld om de overstap naar een andere functie of een andere afdeling te maken. Bedrijven bieden vervolgens cursussen of trainingen aan of laten personeel intern doorstromen om de benodigde competenties te ontwikkelen. 
Ontwikkelen à la carte: E-miles

Sommige bedrijven experimenteren met een à la carte menu van ontwikkelmogelijkheden. Zo is Philips dit jaar gestart met $E$ (mployabiliy)-miles: elke werknemer krijgt 1.000 E-miles die de werknemer naar eigen inzicht kan besteden aan specifieke ontwikkelactiviteiten, zoals (loopbaan)adviesgesprekken en testen. Het aantal E-miles is niet toereikend om alle ontwikkelactiviteiten te volgen, zodat de werknemer een keuze moet maken. Het E-milesprogramma van Philips is gericht op het bewust maken van zowel het management als de werknemers van de noodzaak tot continue persoonlijke ontwikkeling en training van alle medewerkers.

Naast het ontwikkelen van de benodigde competenties is het ook belangrijk om het aanwezige personeel zo optimaal mogelijk te benutten. Medewerkers verschillen niet alleen qua competenties van elkaar, maar ook qua functie-inhoud (veel of weinig verschillende taken; meer zelfstandig moeten werken of veel moeten samenwerken), werktijden (steeds het zelfde of juist wisselende werkdagen en tijden), fase in het arbeidsproces (schoolverlater of een oudere werknemer die bijna met pensioen gaat), etc. Door veranderingen door te voeren die rekening houden met deze verschillen zullen de kwaliteiten van medewerkers optimaler benut kunnen worden. Het valt te verwachten dat dit niet alleen de bedrijfsprestaties ten goede komt, maar ook de ontplooiing van de medewerkers zelf.

Figuur 5.3 laat de ontwikkeling zien van de toekomstige speerpunten in het HRMbeleid in de periode 2005-2008 die gericht zijn op de optimale inzet van het personeel. Het bevorderen van de inzet van het personeel is met ongeveer 4 op de 5 bedrijven in de Metalektro veruit het meest genoemde speerpunt. Het blijvend hoge percentage maakt duidelijk dat het veel bedrijven nog onvoldoende is gelukt om deze inzetbaarheid te bevorderen. In de figuren 5.4 en 5.5 zal dieper op de inzetbaarheid van het technisch personeel worden ingegaan. Aangezien de mogelijkheden en ambities ten aanzien van werk kunnen verschillen naar leeftijd, heeft een aantal bedrijven plannen om een leeftijdsbewust personeelsbeleid te gaan voeren. Ook dit percentage schommelt al een aantal jaren rond de 30\% van de metalektrobedrijven. Maatregelen gericht op een specifieke leeftijdsgroep, namelijk de werknemers van 45 jaar en ouder stonden in de afgelopen jaren steeds vaker op de agenda, maar zijn in 2007 en 2008 gestabiliseerd op ongeveer een vijfde van de bedrijven. Dergelijke maatregelen zijn doorgaans ingegeven door de vergrijzing van het personeelsbestand (zie hoofdstuk 6). Tot slot willen meer bedrijven flexibele werktijden gaan invoeren: in 2006 en 2007 betrof het iets meer dan IO\% van de bedrijven en in 2008 gaat het al om ruim $20 \%$ van de bedrijven in Metalektro. 


\section{Figuur 5.3}

Speerpunten toekomstig HRM-beleid gericht op optimale benutting personeel, 2005-2008 (\% bedrijven)

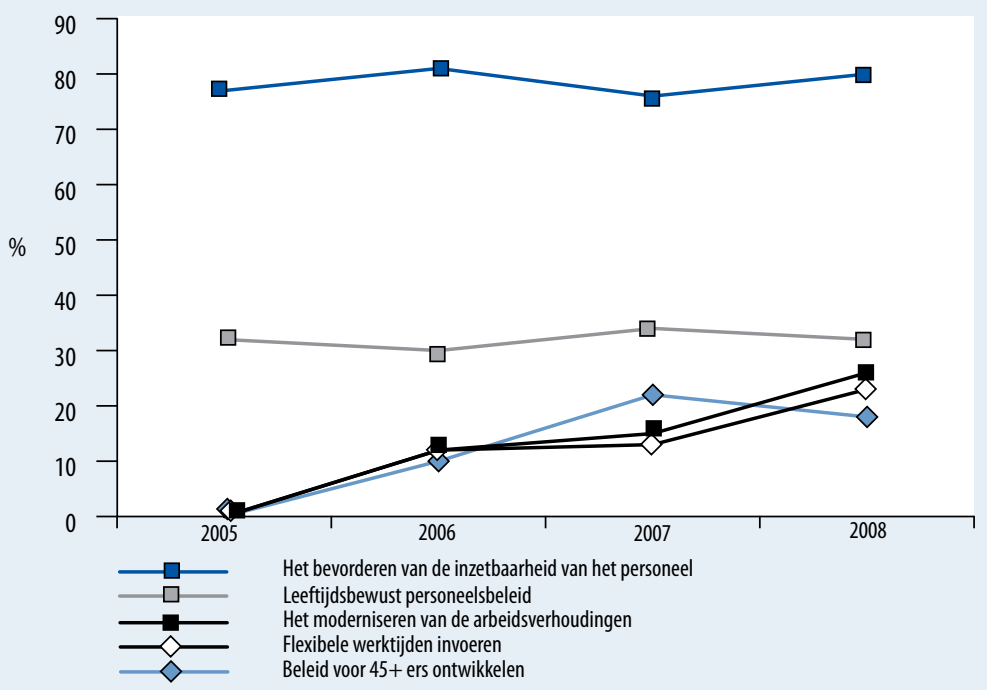

Bron: ROA / Werkgeverspanel Metalektro

\section{Brede inzetbaarheid}

Uit figuur 5.3 is gebleken dat het bevorderen van de inzetbaarheid een zeer belangrijk en veelgenoemd aspect is van het HRM-beleid in de toekomst. In figuur 5.4 is te zien waarom. Om te beginnen is de behoefte aan breed inzetbare medewerkers nog steeds groot. Dit geldt zeker voor het personeel met een uitvoerende technische functie: $54 \%$ van de bedrijven heeft voor die functies vaak behoefte aan breed inzetbare mensen en nog eens $40 \%$ af en toe (zie bovenste helft van figuur 5.4). Brede inzetbaarheid is daarnaast vooral wenselijk in leidinggevende en ondersteunende technische functies. De behoefte aan breed inzetbaar personeel in de niet-technische functies is duidelijk minder groot dan bij de technische functies.

\section{Inzetbaarheid vergroten tijdens WTV-periode}

De WTV-regeling is soms aangegrepen om de inzetbaarheid van het personeel te vergroten. $0 \mathrm{~m}$ dit doel te bereiken gebruiken sommige metalektrobedrijven de leegloopuren om medewerkers te laten meedraaien op andere afdelingen of om hen cursussen te laten volgen die hun inzetbaarheid vergroten. 
Figuur 5.4

Behoefte aan en daadwerkelijke brede inzetbaarheid van het personeel, 2008 (\% bedrijven)

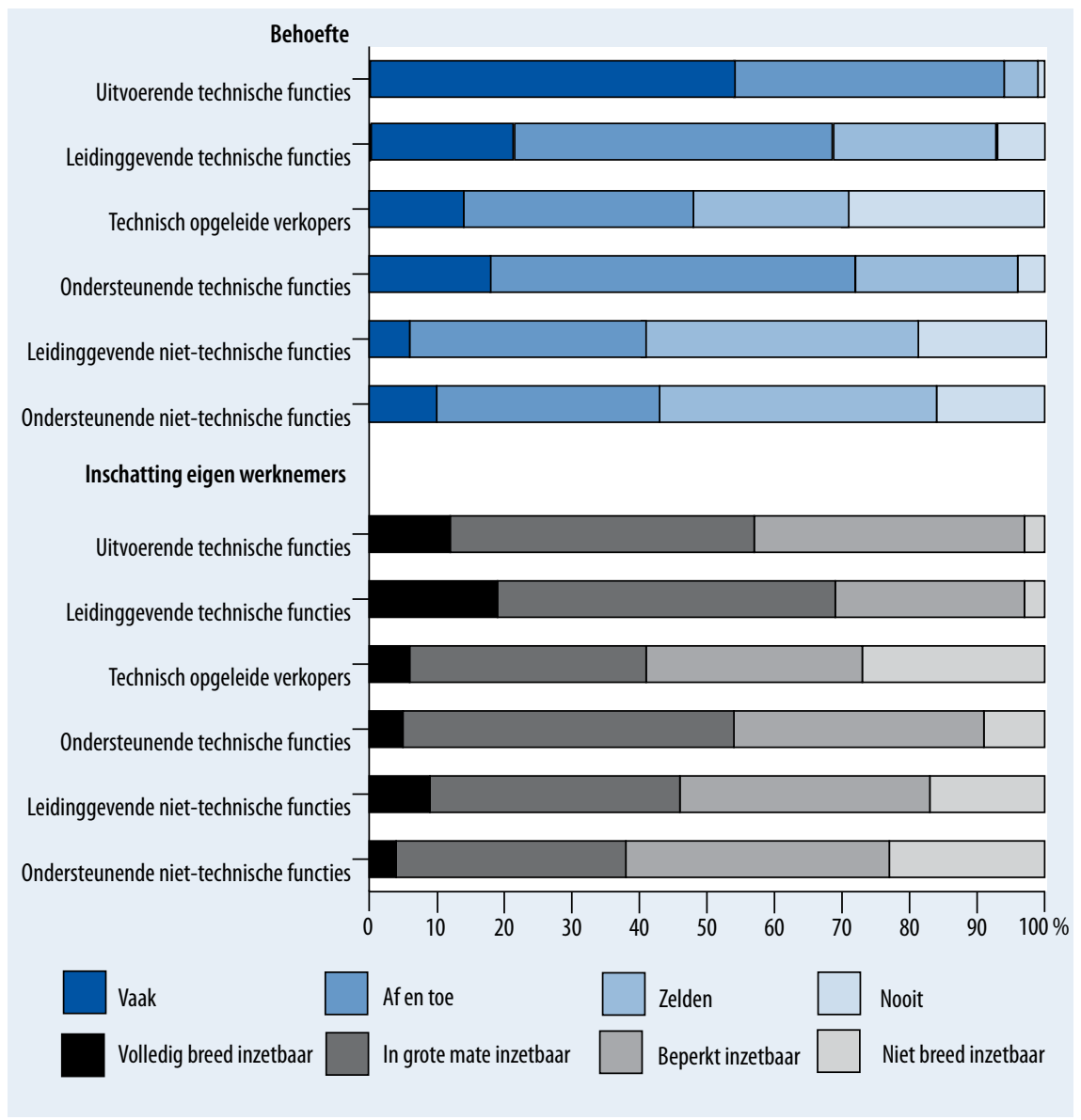

Bron: ROA / Werkgeverspanel Metalektro

Het onderste deel van figuur 5.4 laat zien hoe breed inzetbaar het personeel in de verschillende functies volgens de bedrijven daadwerkelijk is: $69 \%$ van de bedrijven vindt de medewerkers in leidinggevende technische functies in grote mate of volledig breed inzetbaar. Bij de uitvoerende en de ondersteunende technische functies denkt meer dan de helft van de bedrijven er zo over. Een vergelijking tussen de behoefte aan brede inzetbaarheid en de feitelijke inzetbaarheid van het personeel lijkt er op te wijzen dat in veel bedrijven de behoefte aan brede inzetbaarheid groter is dan de feitelijke inzetbaarheid. Dit zou een verklaring kunnen zijn voor het constant hoge percentage bedrijven dat de inzetbaarheid van het personeel via zijn HRM-beleid wil bevorderen. Dit is echter wel sterk afhankelijk van het soort functie: de technisch opgeleide verkopers zijn bijvoorbeeld relatief het minst breed inzetbaar, maar dit hoeft niet tot problemen te leiden aangezien de behoefte aan breed inzetbare technisch 
opgeleide verkopers niet zo groot is. Per functie zal dus goed gekeken moeten worden naar de behoefte aan brede inzetbaarheid en de feitelijke inzetbaarheid van de mensen die de betreffende functie uitoefenen voordat actie wordt ondernomen om de inzetbaarheid te verbreden.

Figuur 5.4 heeft duidelijk gemaakt dat er vooral bij uitvoerende technische functies nog vaak behoefte is aan breed inzetbaar personeel. Maar waar komt die behoefte aan brede inzetbare uitvoerende technici vandaan? Figuur 5.5 laat zien dat schommelingen in de bedrijvigheid al een aantal jaren door ongeveer 4 van de 5 metalektrobedrijven als reden wordt genoemd. Het is hiermee de meest genoemde reden om breed inzetbare technici te willen hebben. Andere redenen die door veel bedrijven genoemd worden, zijn het aantrekkelijker maken van de functies, het opvangen van ziekteverzuim en het voor vervanging kunnen zorgen als een medewerker met verlof is. Opvallend is wel dat al deze redenen vanaf 2006 elk jaar door een kleiner percentage bedrijven worden genoemd. In dezelfde periode noemt gemiddeld een derde van de bedrijven ook de tekorten aan bepaalde werknemers als reden voor de behoefte aan breed inzetbaar personeel.

\section{Figuur 5.5}

Redenen voor behoefte aan breed inzetbare uitvoerende technici, 2005-2008 (\% bedrijven)

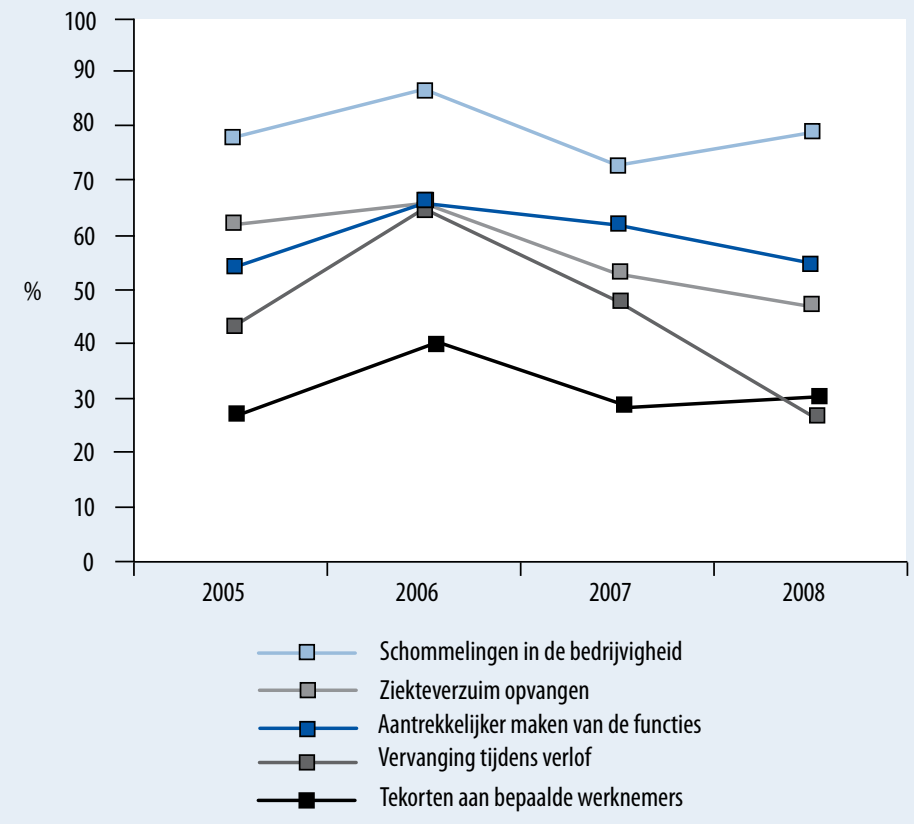

Bron: ROA / Werkgeverspanel Metalektro 


\section{Afstemming werk en privé}

Wanneer het werk de privésituatie in de weg zit of andersom, dan zal een medewerker waarschijnlijk niet optimaal presteren. $87 \%$ van de metalektrobedrijven vindt zichzelf al flexibel in de afstemming van werk en privé van haar medewerkers. Echter, 59\% van de bedrijven maakt wel het voorbehoud dat de functie deze flexibiliteit moet toelaten.

\section{Figuur 5.6}

Aangeboden mogelijkheden voor afstemming werk privé, 2008 (\% bedrijven)

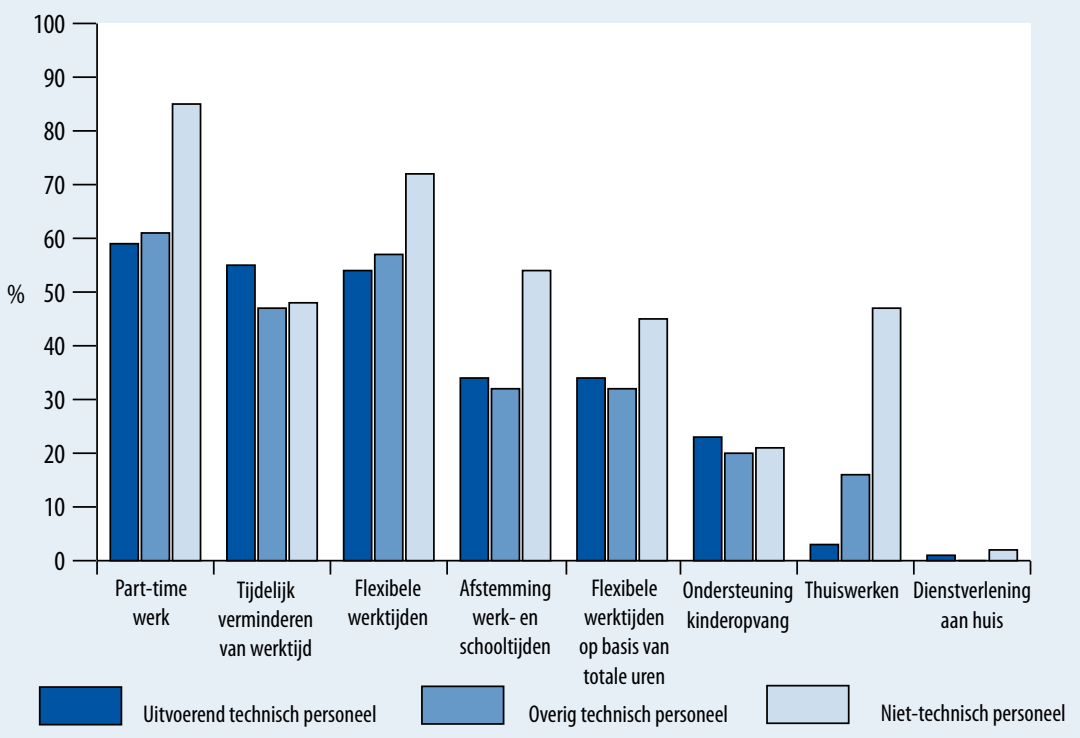

Bron: ROA / Werkgeverspanel Metalektro

De aangeboden mogelijkheden om werk en privé op elkaar af te stemmen bestaan voornamelijk uit traditionele vormen als parttime werken, het tijdelijk minder werken en het werken op flexibele tijden. In figuur 5.6 is te zien dat de bedrijven deze mogelijkheden vaker aanbieden aan hun niet-technisch personeel dan aan hun technisch personeel. In ongeveer $60 \%$ van de bedrijven is parttime werken mogelijk voor het uitvoerend en ondersteunend technisch personeel, terwijl in maar liefst $85 \%$ van de bedrijven het niet-technisch personeel parttime kan werken als men dat wil. De mogelijkheid tot parttime werk wordt significant vaker door grote bedrijven (>IOO medewerkers) aan het uitvoerend technisch personeel aangeboden dan door middelgrote ( $5 \mathrm{I}-\mathrm{IOO}$ medewerkers) en kleinere bedrijven (I-50 medewerkers). Van de kleinere en middelgrote bedrijven biedt $45 \%$ en $50 \%$ parttime werk aan, terwijl dit percentage bij de grotere bedrijven op $75 \%$ ligt. 
Ook het thuiswerken wordt door bijna de helft van de bedrijven aan het niet-technisch personeel aangeboden, terwijl het technisch personeel in slechts $3 \%$ van de bedrijven thuis kan werken. Dat het technisch personeel minder mogelijkheden krijgt aangeboden om de werksituatie af te stemmen op de privésituatie dan het niet-technisch personeel, kan onder andere worden verklaard door praktische bezwaren: thuiswerken is immers onmogelijk als de benodigde apparatuur voor het werk niet mee naar huis genomen kan worden.

Het percentage bedrijven dat de afstemming werk privé opneemt als speerpunt van het HRM-beleid van de komende jaren neemt overigens wel toe. In 2007 had $15 \%$ van de bedrijven dit als speerpunt opgenomen. In 2008 is dat percentage gestegen tot $24 \%$ van de bedrijven in de Metalektro.

\subsection{Externe samenwerking}

De tot dus ver besproken vormen van sociale innovatie hebben vrijwel uitsluitend betrekking op de 'binnenkant' van het bedrijf: de medewerkers, de organisatie en het management. Bedrijven functioneren echter al lang niet meer als geïsoleerde eilanden, maar werken op diverse manieren samen met externe partijen. En als deze samenwerking er nog niet is of nog onvoldoende intensief, dan zijn er vaak wel plannen om samenwerking te bewerkstellingen. Zo is $4 \mathrm{I} \%$ van de metalektrobedrijven van plan om de komende 5 jaar intensiever samen te gaan werken met onderwijsinstellingen. En $17 \%$ van de bedrijven zoekt in diezelfde periode naar een intensievere samenwerking met andere bedrijven.

Een specifieke vorm van samenwerken met andere bedrijven is het uitbesteden van eigen activiteiten aan een ander bedrijf. De stevige groei in het uitbesteden van productie- en onderzoeksactiviteiten zoals die vorig jaar werd waargenomen, zet in de komende vijf jaar niet door (zie figuur 5.7). Integendeel, het aantal bedrijven dat activiteiten uitbesteed naar buitenlandse bedrijven neemt zelfs af. In 2007 gaf ruim één op de drie bedrijven aan dat er meer productieactiviteiten uitbesteed zouden gaan worden aan buitenlandse bedrijven. In 2008 was dit nog slechts bij één van de vijf bedrijven het geval. Bij de geplande verplaatsing van onderzoeksactiviteiten naar het buitenland is de daling ook drastisch: van IO\% van de bedrijven in 2007 naar $5 \%$ in 2008. Verder heeft I8\% van de bedrijven plannen om meer ondersteunende activiteiten uit te besteden aan een in Nederland gevestigd bedrijf. Slechts één van de tien bedrijven denkt meer administratieve activiteiten uit te gaan besteden en dan alleen aan andere Nederlandse bedrijven. Dit is vrijwel evenveel als in 2007. 
Figuur 5.7

Uitbesteding van activiteiten in de komende 5 jaar, 2007-2008 (\% bedrijven)

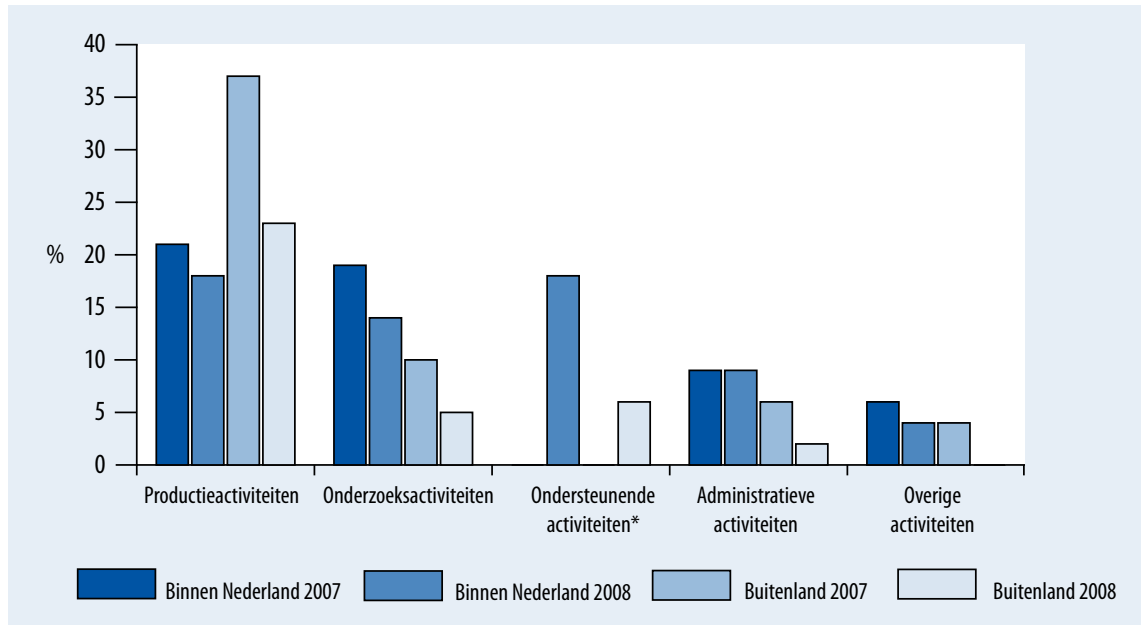

* Deze antwoordoptie is voor het eerst in de meting van 2008 opgenomen, vandaar dat de percentages voor 2007 ontbreken.

Bron: ROA / Werkgeverspanel Metalektro

\subsection{Knelpunten bij de uitvoering van sociale innovatie}

Sociale innovatie betekent per definitie verandering. Om veranderingen mogelijk te maken dienen bedrijven onder andere hun focus te richten op de lange termijn in plaats van op de korte termijn. Daarnaast is het creëren en behouden van een bedrijfscultuur waarin experimenteren wordt aangemoedigd en fouten maken mag, een absolute must om als bedrijf te kunnen innoveren. Ook is het van groot belang dat werknemers in hun employability kunnen en willen investeren en bereid zijn tot verandering. ${ }^{5}$ Des te meer van deze factoren aanwezig zijn in een bedrijf, des te groter de kans van slagen van sociale innovatie. Wanneer de genoemde factoren echter (gedeeltelijk) ontbreken, ontstaan er knelpunten waardoor de noodzakelijke veranderingen slechts gedeeltelijk of helemaal niet plaatsvinden.

Figuur 5.8 geeft een overzicht van de knelpunten die bedrijven tegenkomen bij de uitvoering van sociale innovatie. Het blijkt dat de menselijke factor het vaakst als knelpunt wordt genoemd. Lang niet al het personeel kan bijvoorbeeld goed omgaan met veranderingen of ontbeert de noodzakelijke flexibiliteit: in 2008 denkt $38 \%$ van de bedrijven dat haar personeel niet goed met veranderingen om kan gaan en bij 3I\% van de bedrijven is de flexibiliteit van het personeel onvoldoende.

5. Taskforce Sociale Innovatie (2005), Sociale innovatie, de Andere Dimensie, Eindrapport, Den Haag. 
Waarom veranderen, hebben we het dan al die tijd niet goed gedaan?

Bedrijven in de Metalektro met relatief veel personeel dat al vele jaren voor het bedrijf werkt, kunnen meer problemen ervaren bij het doorvoeren van veranderingen. Medewerkers vinden het doorgaans niet prettig om afscheid te nemen van een vertrouwde manier van werken ten gunste van een nieuwe onbekende werkwijze. De nieuwe werkwijze kan medewerkers bijvoorbeeld het gevoel geven dat ze het al die tijd niet goed hebben gedaan.

3 van de Io bedrijven denkt dat het kennisniveau van hun medewerkers te laag is om sociale innovatie tot een succes te maken. Dit verschilt overigens niet veel van het beeld dat in de jaren 2006 en 2007 naar voren kwam. Zorgwekkend is wel dat het percentage bedrijven dat onvoldoende budget voor sociale innovatie heeft, toeneemt: in 2006 noemde I op de Io bedrijven dit knelpunt, maar in 2008 is dit toegenomen tot I op de 4 bedrijven. Deze toename is waarschijnlijk mede een gevolg van de crisis.

Overigens verwacht $28 \%$ van de bedrijven geen knelpunten. Sociale innovatie kan ook worden bemoeilijkt door personeel dat niet in zichzelf lijkt te willen investeren of onvoldoende gemotiveerd is. Soms werkt de direct leidinggevende ook onvoldoende mee. Al deze factoren worden in 2008 wel iets minder vaak als knelpunt genoemd dan in 2007.

\section{Figuur 5.8}

Factoren die sociale innovatie kunnen afremmen, 2006-2008 (\% bedrijven)

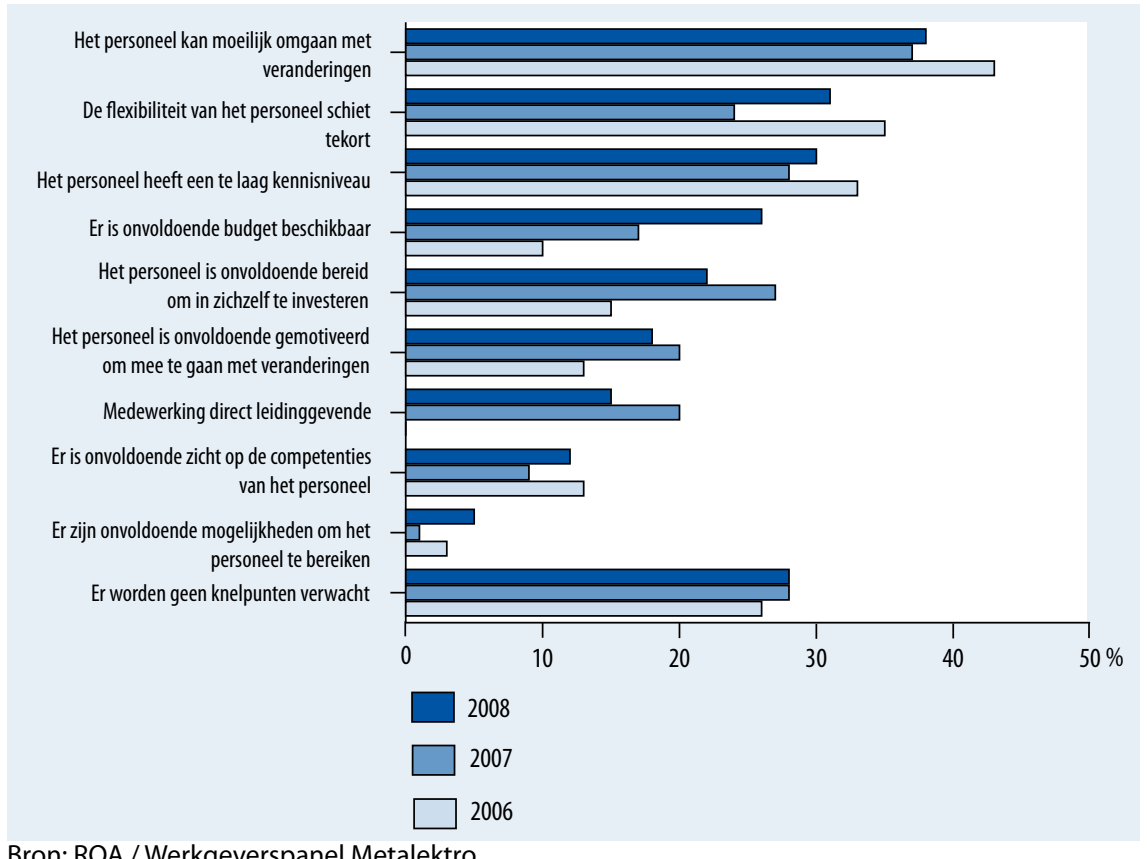





\section{Vergrijzing en active aging beleid}

In dit hoofdstuk wordt ingegaan op de verwachte omvang van de personeelsuitstroom als gevolg van de pensionering van oudere werknemers en welke problemen dit met zich mee brengt. Daarnaast geeft dit hoofdstuk een beeld van die maatregelen die de metalektrobedrijven nemen om hierop in te spelen. Deze maatregelen hebben enerzijds betrekking op het beperken van de problemen die ontstaan door de pensioneringsuitstroom. Anderzijds gaat het om het HRM beleid dat zich richt op het op peil houden van de inzetbaarheid van de oudere werknemer.

\subsection{Uitstroom door vergrijzing en vervangingsproblemen}

Een flink deel van de werknemers in de Metalektro is 50 jaar of ouder (21\%). Dit betekent dat de metalektrobedrjiven met behoorlijk wat uitstroom als gevolg van pensionering te maken hebben en dat deze uitstroom de komende jaren zal toenemen.

Figuur 6.I laat zien dat metalektrobedrijven relatief de meeste uitstroom verwachten van de uitvoerende technische functies. In deze functies zal 8,7\% van de werkenden in de komende 5 jaar met pensioen gaan. Bij de technische opgeleide verkopers zwaait ruim $6 \%$ binnen enkele jaren af. Voor de andere functies liggen de uitstroompercentages lager: $4,5 \%$ van de leidinggevende functies, 3,8\% van de ondersteunende technische functies, I,9\% van de leidinggevende niet-technische functies en 3,0\% van de ondersteunende niet-technische functies zal de komende 5 jaar met pensioen gaan.

In vergelijking tot voorgaande jaren is er een aantal veranderingen te bespeuren. De toename van het percentage uitvoerende technici dat met pensioen gaat heeft zich in 2008 niet doorgezet. Er is hier zelfs sprake geweest van een minieme daling van de uitstroom vanwege pensionering. Hetzelfde beeld zien we bij de ondersteunende technische functies. Ook hier was het verwachte percentage werknemers dat met pensioen gaat in 2006 en 2007 hoger dan het jaar ervoor, maar in 2008 is de verwachte uitstroom weer lager dan in 2007. Daarentegen zet de stijgende lijn zich wel door bij de technisch opgeleide verkopers: waar de voor de komende jaren verwachte pensioenuitstroom in 2008 bijna tweemaal zo groot is als in 2006 en 2007. Bij de leidinggevende technische functies was er in 2008 ook weer een kleine stijging te zien in de verwachte pensioenuitstroom ten opzichte van de jaren 2006 en 2007. 


\section{Figuur 6.1}

Percentage werknemers dat binnen 5 jaar met pensioen gaat naar functiecategorie, 2005-2008

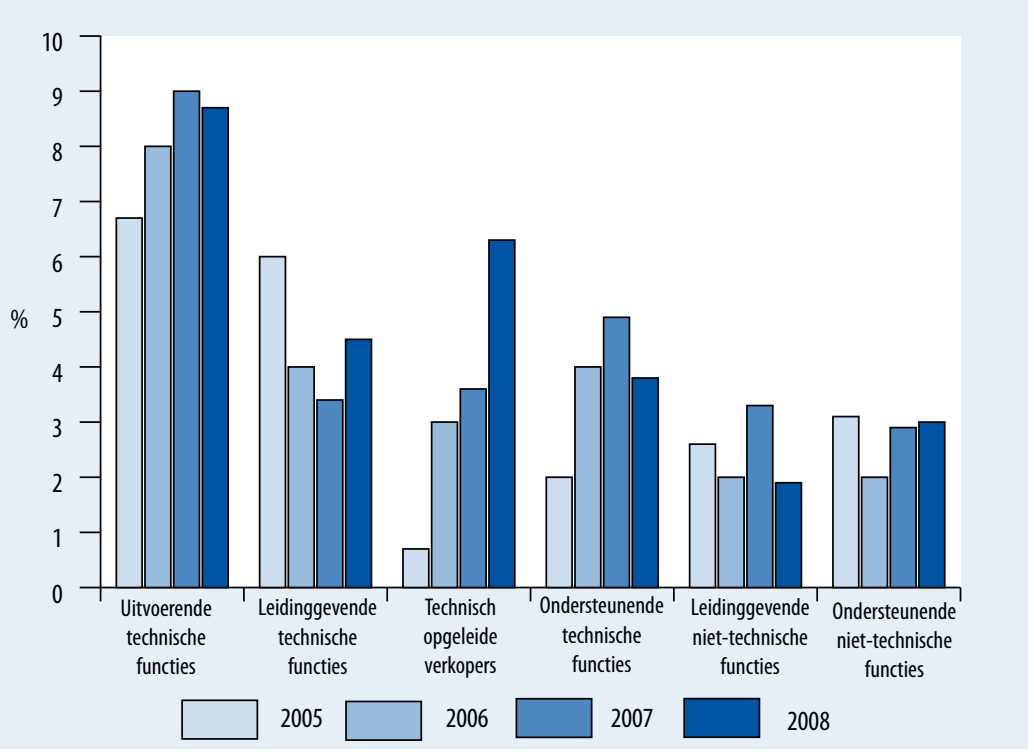

Bron: ROA / Werkgeverspanel Metalektro

Aan de bedrijven is vervolgens gevraagd om een inschatting te maken van de verwachte problemen die de vervanging van deze gepensioneerden zal opleveren. Uit figuur 6.2 blijkt dat 39\% van de bedrijven waar de komende jaren personeel met pensioen gaat veel problemen verwacht bij de vervanging van gepensioneerde uitvoerende technici, terwijl $38 \%$ van de bedrijven matige problemen verwacht. De bedrijven verwachten echter nog meer problemen bij de vervanging van leidinggevende technici en ondersteunende technici: $34 \%$ van de bedrijven verwacht veel problemen en $53 \%$ matige problemen om leidinggevende technici te vervangen. Bij de ondersteunende technici verwacht $56 \%$ van de bedrijven matige en $31 \%$ veel problemen bij de vervanging van het personeel dat met pensioen gaat. De allergrootste problemen worden echter verwacht bij de vervanging van technisch opgeleide verkopers: $46 \%$ van de bedrijven verwach matige problemen en maar liefst $48 \%$ veel problemen om deze mensen te vervangen.

Het percentage bedrijven dat problemen verwacht bij de vervanging van gepensioneerde uitvoerende technici nam aanvankelijk toe in de periode 2005-2007, maar is in 2008 weer iets lager dan in 2007 (zie figuur 6.3). De ontwikkeling van de verwachte problemen bij de vervanging van leidinggevende, ondersteunende technische functies en technisch opgeleide verkopers laat echter een continue stijgende lijn zien. Wat hierbij opvalt, is dat de stijging bij de technisch opgeleide verkopers relatief het grootst is. De trends die te zien zijn in figuur 6.3 zijn vrijwel een kopie van de trends in figuur 6.2. Dit wijst er sterk op dat een hogere uitstroom van technici die met pensioen gaan leidt tot een stijging van het aantal bedrijven dat vervangingsproblemen verwacht. 


\section{Figuur 6.2}

Verwachte problemen bij het vervangen van werknemers die in de komende 5 jaar met pensioen gaan per functiecategorie, 2008 (\% bedrijven)

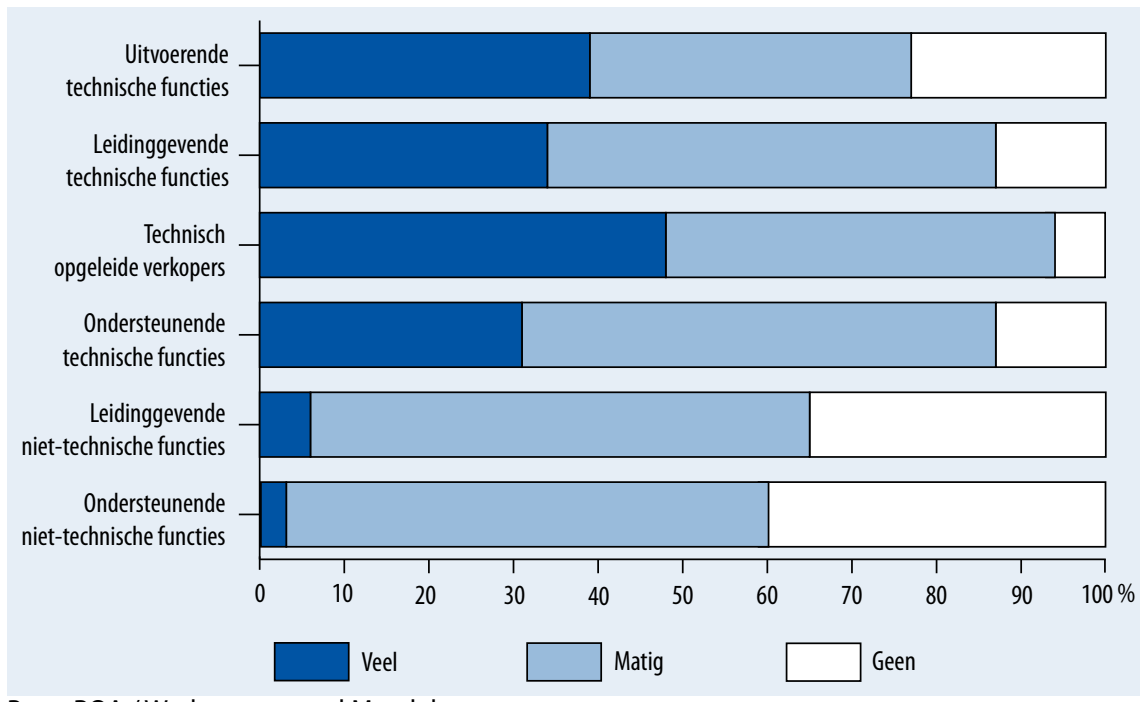

Bron: ROA / Werkgeverspanel Metalektro

Figuur 6.3

Verwachte problemen bij het vervangen van toekomstige gepensioneerde technici, 2005-2008 (\% bedrijven)*

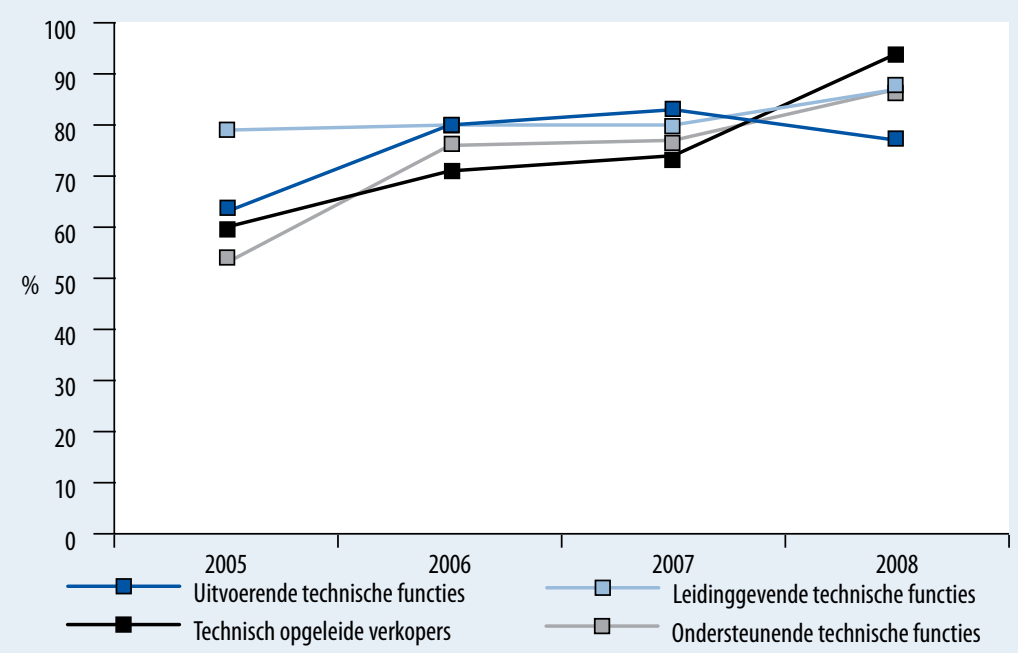

* De getoonde percentages zijn een optelsom van het percentage bedrijven dat veel problemen verwacht en het percentage bedrijven dat matige problemen verwacht bij de vervanging van technisch personeel in de betreffende functie.

Bron: ROA / Werkgeverspanel Metalektro 
Wanneer een ervaren medewerker met pensioen gaat, is het ten eerste niet eenvoudig om überhaupt een vervanger te vinden. Bovendien zal de persoon die de gepensioneerde vervangt waarschijnlijk niet over dezelfde werkervaring en competenties beschikken als de gepensioneerde. In deze omstandigheden is het zeer aannemelijk dat des te meer personeelsleden in een bedrijf met pensioen gaan, des te meer vervangingsproblemen dit bedrijf zal hebben.

\subsection{Aanpak vervangingsproblemen ontstaan door vergrijzing}

De meeste bedrijven die problemen verwachten met het vervangen van hun gepensioneerde werknemers kijken niet lijdzaam toe, maar ondernemen actie. $72 \%$ van deze bedrijven heeft concrete maatregelen voor ogen om de verwachte vervangingsproblemen zo veel mogelijk te beperken. Zoals figuur 6.4 laat zien zijn de meeste maatregelen ook al uitgevoerd. Echter, een deel van de bedrijven wil deze maatregelen pas in de toekomst uitvoeren.

\section{Figuur 6.4}

Maatregelen om toekomstige vervangingsproblemen te beperken, 2008 (\% bedrijven)

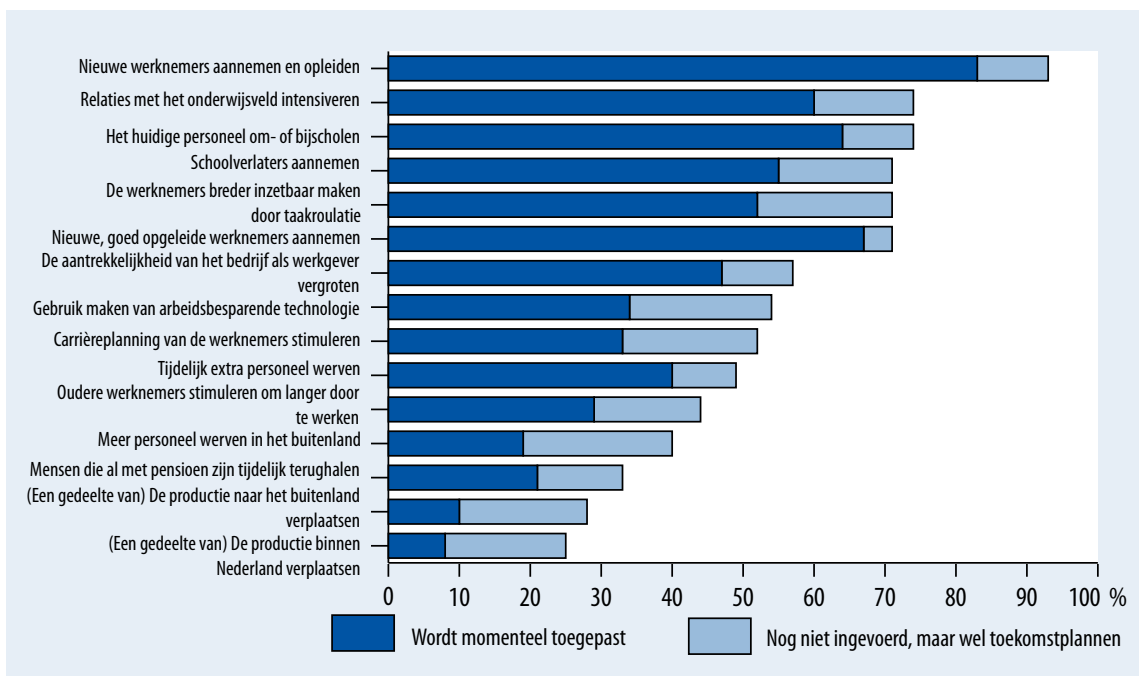

Bron: ROA / Werkgeverspanel Metalektro

De meest populaire maatregel is het aannemen en opleiden van nieuwe werknemers. $83 \%$ van de bedrijven die maatregelen voor ogen hebben is hier al mee bezig en nog eens IO\% zal dit in de toekomst gaan doen. Daarnaast wil $74 \%$ van de bedrijven de banden met het onderwijs verstevigen: $60 \%$ heeft dat al gedaan en $\mathrm{I} 4 \%$ heeft plannen daartoe. Deze wens voor stevigere banden met het onderwijsveld heeft vermoedelijk te maken met de volgende twee meest genoemde maatregelen: het huidige personeel om- of bijscholen (64\% al uitgevoerd, IO\% gepland) en schoolverlaters aannemen. $55 \%$ 
van de bedrijven doet dit al en I6\% wil dit de komende jaren gaan doen. Daarnaast zijn er bedrijven die hun personeel breder inzetbaar maken (52\%) of willen maken (19\%) door hen regelmatig van taak te laten rouleren. Veel bedrijven proberen toekomstige vervangingsproblemen ook te beperken door het aannemen van nieuwe werknemers die al goed opgeleid zijn.

Het verplaatsen van de productie is daarentegen een weinig gebruikt middel om de verwachte vervangingsproblemen als gevolg van gepensioneerde medewerkers tegen te gaan. Echter, voor een aantal bedrijven is het verplaatsen van de productie een serieuze optie: I8\% van de bedrijven wil in de toekomst een deel van de productie naar het buitenland verplaatsen en $17 \%$ wil de productie binnen Nederland verplaatsen.

\section{Figuur 6.5}

Maatregelen om toekomstige vervangingsproblemen te beperken, 2003 en 2005-2008 (\% bedrijven)

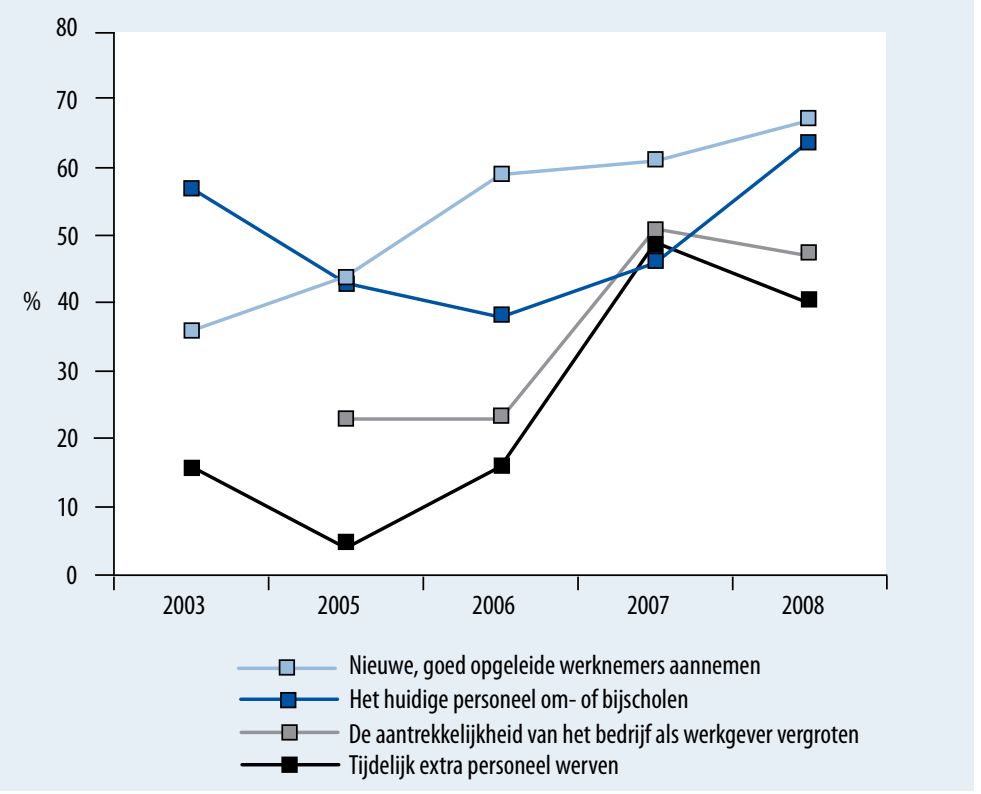

Bron: ROA / Werkgeverspanel Metalektro

Wanneer wordt gekeken naar de ontwikkeling in de tijd van de in figuur 6.4 genoemde maatregelen om de vervangingsproblematiek te beperken, dan blijkt dat de meeste bedrijven zich hierbij steeds meer richten op het aannemen van nieuwe goed opgeleide werknemers (zie figuur 6.5). Verder heeft het omscholen van personeel eerst een teruggang in populariteit gekend, maar wordt dat in 2008 weer door een vergelijkbaar percentage bedrijven gedaan als in 2003. De bedrijven in de Metalektro zijn in een tijdsbestek van enkele jaren ook steeds nauwer met scholen gaan samenwerken en schoolverlaters gaan aannemen. Het inzetten van taakroulatie kent daarentegen 
de afgelopen jaren een zeer grillig verloop. Tot slot is er een gestage toename van het aantal bedrijven dat zich richt op het vergroten van de aantrekkelijkheid van het bedrijf als werkgever. Hetzelfde geldt voor het tijdelijk extra personeel werven. Echter, beide maatregelen zijn in 2008 weer minder populair dan in 2007 (zie figuur 6.5).

\subsection{Active aging}

Twee van de in paragraaf 6.2 genoemde maatregelen om de toekomstige vervangingsproblemen te beperken, hebben betrekking op de oudere medewerkers zelf. Het gaat om de maatregelen "oudere werknemers stimuleren om langer door te werken" en "mensen die met pensioen zijn tijdelijk terughalen". In 2008 zegt $29 \%$ van de bedrijven hun oudere werknemers al te stimuleren om langer te blijven werken en $15 \%$ is dit van plan te gaan doen. Ook zegt $2 \mathbf{I} \%$ van de bedrijven dat ze gepensioneerden tijdelijk terughalen terwijl I2\% dat van plan is (zie figuur 6.4).

Wanneer oudere werknemers langer doorwerken of tijdelijk terugkeren uit hun pensioensituatie vermindert de vervangingsbehoefte. Maar hoe stimuleer je als werkgever het langer doorwerken van oudere werknemers en hoe haal je een gepensioneerde medewerker tijdelijk terug in het werkproces? Het antwoord op deze vraag is het voeren van wat meestal wordt aangeduid als een active aging beleid. Active aging beleid is een verzamelnaam voor maatregelen die gericht zijn op de duurzame inzetbaarheid van werknemers door rekening te houden met iemands leeftijd en de specifieke behoeften van het oudere personeel. Figuur 6.6 laat zien op welke manier aan dit active aging beleid in de Metalektro wordt vormgegeven.

\section{Wettelijke regelingen stimuleren active aging beleid}

Overigens lijken wettelijke regelingen rond ziekteverzuim en reintegratie de metalektrobedrijven te stimuleren om het werk voor hun oudere werknemers aan te passen. Bij oudere werknemers kan bovenmatig ziekteverzuim een indicatie zijn dat zij het werk niet meer op de reguliere manier kunnen doen. Bedrijven laten deze personen vervolgens alleen dagdiensten werken en/of passen hun takenpakket aan. 


\section{Figuur 6.6}

Active aging instrumenten die metalektrobedrijven inzetten voor het technisch personeel van 45 jaar en ouder, 2005-2008 (\% bedrijven)

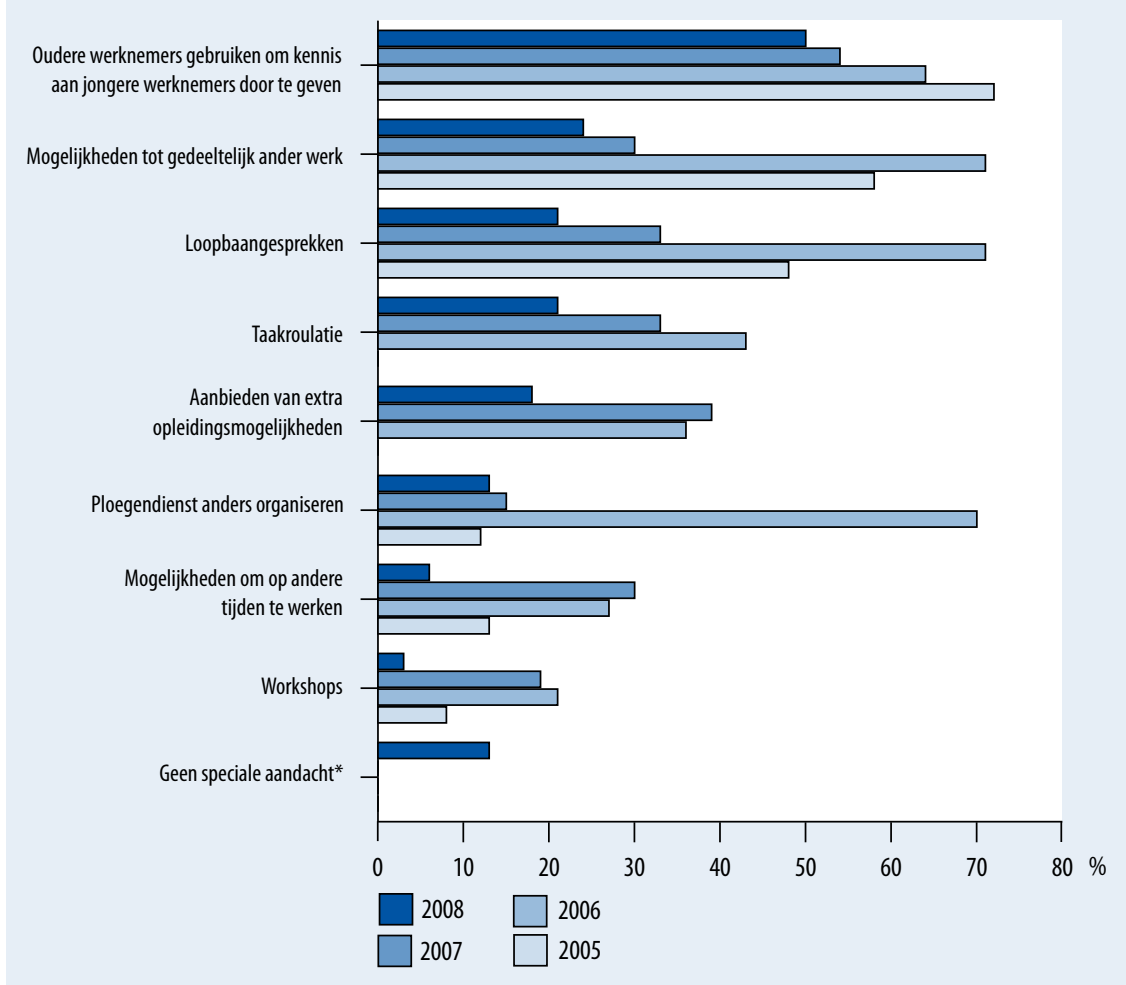

* Deze antwoordoptie is verkregen uit de antwoorden van de categorie 'Anders', vandaar dat de percentages voor 2005-2007 ontbreken.

Bron: ROA / Werkgeverspanel Metalektro

De metalektrobedrijven die specifieke aandacht aan hun technici van 45 jaar en ouder besteden, doen dit vooral door hun oudere technici zodanig in te zetten dat zij hun kennis aan de jongere garde kunnen doorgeven. In 2008 zegt 50\% van de bedrijven hun oudere technici op die manier in te zetten. Ook zoekt bijna een kwart van de bedrijven naar mogelijkheden om oudere technische werknemers gedeeltelijk ander werk te geven. Daarnaast lijken de gebruikte maatregelen gericht te zijn op het op peil houden van de competenties van de oudere technici via taakroulatie (2I\%), extra opleidingsmogelijkheden (I8\%) en workshops (3\%). Een nadere bestudering van de ingezette active aging instrumenten in de afgelopen vier jaar laat duidelijk zien dat het gebruik van de meeste instrumenten in die periode is afgenomen. Dit is zeer opmerkelijk, gezien de toenemende vergrijzingsproblematiek waarmee veel bedrijven worden geconfronteerd. Wellicht dat men niet tevreden is over de effectiviteit van de instrumenten of dat men ze te duur vindt. 
Door te blijven investeren in het competentieniveau van de oudere technici via opleidingen, workshops en taakroulatie blijft het oudere technische personeel langer inzetbaar in het bedrijf. Uit de Quickscan blijkt dat de meeste bedrijven vinden dat het wel degelijk zin heeft om te investeren in de competenties van de werknemers van 45 jaar en ouder. $83 \%$ is het namelijk oneens met de stelling "Het heeft weinig zin om nog veel te investeren in het op peil houden van de competenties van het oudere personeel." Opvallend is wel dat de meningen variëren naar bedrijfsgrootte zoals in figuur 6.7 is te zien. Van de bedrijven met minder dan Ioo medewerkers is namelijk $37 \%$ het helemaal oneens met de stelling en bij de bedrijven van Ioo tot 250 medewerkers is dit percentage $36 \%$. Bij de bedrijven met meer dan 250 medewerkers is daarentegen maar liefst $72 \%$ het helemaal oneens met deze stelling. Dit wijst erop dat vooral grote bedrijven het zinvol vinden om veel in de competenties van oudere werknemers te investeren.

\section{Figuur 6.7}

Zin van veel investeren in het op peil houden van competenties oudere personeel, naar bedrijfsgrootte, April/Mei 2008 (\% bedrijven)

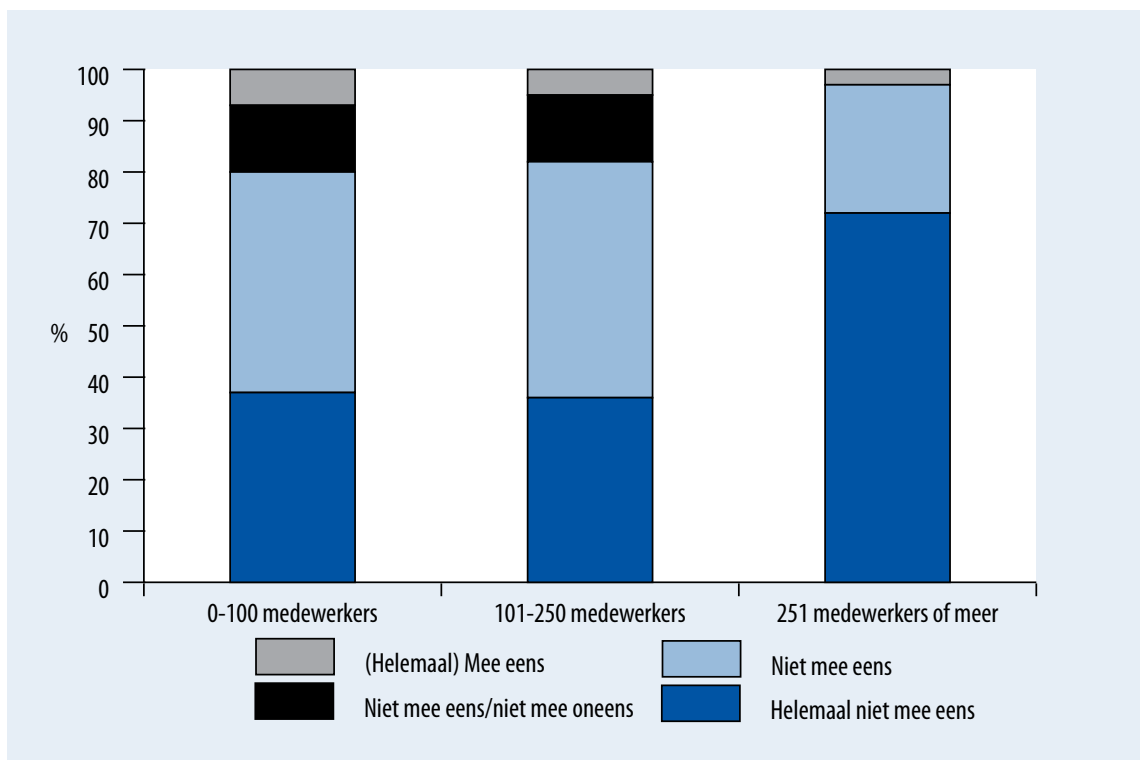

Bron: ROA, Quickscan 


\section{Active aging in de sector 0verheid en Onderwijs}

Ter vergelijking maken we een uitstapje naar de sector overheid en onderwijs, waar men ook probeert via active aging beleid de oudere werknemers te stimuleren om langer door te werken. Uit een werknemersonderzoek in deze sector blijkt dat iets meer dan 2 op de 5 werknemers vindt dat er kennisoverdracht plaatsvindt van oudere naar jongere werknemers (zie figuur 6.8). Ongeveer een derde van de werknemers is van mening dat de organisatie de taakbelasting van oudere werknemers indien nodig aanpast. Verder is ruim een kwart het eens met de stelling dat hun organisatie voldoende investeert in de kennis en vaardigheden van de oudere werknemer. $18 \%$ van de werknemers vindt dat de organisatie waar zij werken veel moeite doet om de oudere werknemers aan zo lang mogelijk aan het werk te houden. Wanneer de resultaten van dit werknemersonderzoek in de sector Overheid en Onderwijs worden vergeleken met de maatregelen die de werkgevers in de Metalektro nemen (zie figuur 6.6) dan valt het op dat er diverse overeenkomsten zijn. In beide sectoren is de kennisoverdracht van oudere naar jongere werknemers het meest gebruikte active aging instrument. 0ok wordt in beide sectoren geïnvesteerd in de kennis en vaardigheden van de oudere werknemers.

\section{Figuur 6.8}

Active aging maatregelen die volgens werknemers in de sector Overheid en Onderwijs worden getroffen door hun werkgevers (\% werknemers)

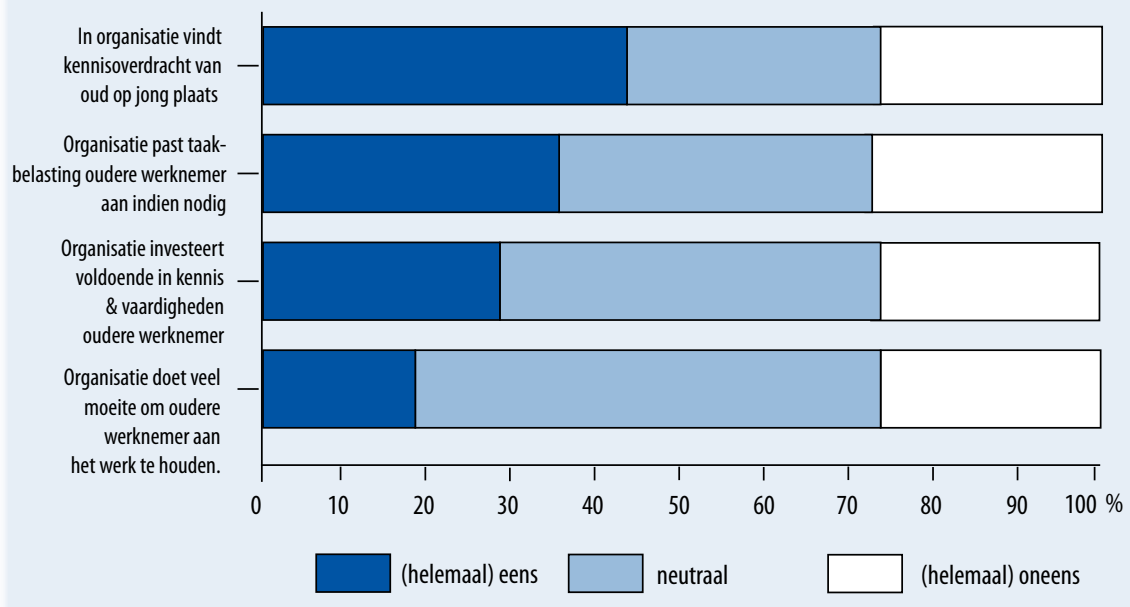

Bron: Loo, J. van, A. de Grip, R. Montizaan (2005), Active Aging bij Overheid en Onderwijs:Vernieuwend omgaan met vergrijzing, $A B P$ belevingsonderzoek, Maastricht (aangepast).

In hetzelfde werknemersonderzoek in de overheids- en onderwijssector is ook aan de werknemers gevraagd welke maatregelen hen zouden stimuleren om langer door te werken. De werknemers van 45 jaar en ouder gaven aan de volgende 5 maatregelen het belangrijkst te vinden: extra seniorendagen (63\%), minder werkdruk (62\%), mogelijkheden tot deeltijdwerk/deeltijdpensioen (59\%), flexibele werktijden (58\%) en ingezet worden als deskundige of specialist (56\%). Hoewel de sector Overheid en Onderwijs wezenlijk verschilt van de Metalektro, bieden de hier genoemde maatregelen een aanknopingspunt voor de loopbaangesprekken tussen werkgevers en hun oudere werknemers in de Metalektro. Active aging beleid blijft immers vóór alles maatwerk.

Door ook loopbaangesprekken te houden met het oudere personeel kunnen metalektrobedrijven op individueel niveau vaststellen op welke manier iemand langer aan het werk kan blijven. 



\section{De Metalektro in de toekomst}

In dit hoofdstuk wordt op basis van verwachtingen van de bedrijven in de Metalektro vooruit gekeken naar de ontwikkelingen in de branche in de komende 2 tot 5 jaar. De eerste paragraaf gaat over de arbeidsmarktontwikkelingen in de Metalektro. Daarna wordt in paragraaf 7.2 ingegaan op de verwachte veranderingen in de werving. De derde paragraaf gaat in op de veranderingen in de functies van technici en paragraaf 7.4 sluit af met de nieuwe ontwikkelingen op HRM gebied.

\subsection{Arbeidsmarktontwikkelingen in de Metalektro op de korte termijn: 2009-2010}

$\mathrm{Al}$ enkele jaren neemt in de Metalektro de werkgelegenheid voor werknemers met een LBO werk- en denkniveau af, terwijl de werkgelegenheid voor werknemers met een werk- en denkniveau op $\mathrm{MBO}$ en $\mathrm{HBO} / \mathrm{WO}$ niveau toeneemt. De arbeidsmarktverwachtingen van de metalektrobedrijven voor 2009 en 2010 wijzen er op, dat deze ontwikkeling in de toekomst zal doorzetten.

In figuur 7.I is te zien dat begin 2009 meer dan de helft van de bedrijven verwacht dat de werkgelegenheid waar een werk- en denkniveau op LBO of $\mathrm{MBO}$ niveau voor nodig is, zich stabiliseert. Voor HBO/WO-functies verwacht zelfs $65 \%$ van de bedrijven dat er de komende twee jaar niets verandert ten opzichte van 2008. Groei van de werkgelegenheid wordt het vaakst verwacht voor functies met een $\mathrm{MBO}$ werken denkniveau: $38 \%$ van de bedrijven. Daarnaast verwacht $28 \%$ van de bedrijven een toename van de werkgelegenheid voor $\mathrm{HBO} / \mathrm{WO}$-functies. Echter, slechts $7 \%$ van de bedrijven denkt dat er meer werk komt op LBO werk- en denkniveau en maar liefst $37 \%$ van de bedrijven verwacht een afname van werkgelegenheid op LBO niveau.

Heeft de crisis effect op de toekomstverwachtingen van bedrijven over de werkgelegenheid? En zo ja, is dat effect voor alle bedrijven gelijk? Een vergelijking van de toekomstverwachtingen uit figuur 7.I met de verwachtingen die metalektrobedrijven in januari 2008 hadden over de werkgelegenheid, laat zien dat de crisis voornamelijk een negatief effect heeft op de verwachte werkgelegenheidsgroei van functies op $\mathrm{MBO}$ en $\mathrm{HBO} / \mathrm{WO}$ niveau. Begin 2008 verwachtte namelijk nog $49 \%$ van de bedrijven een toename in de werkgelegenheid voor MBO-ers, terwijl dit percentage begin 2009 
gedaald is tot $38 \%$ van de bedrijven. Het percentage bedrijven dat een toename in het werk op $\mathrm{HBO} / \mathrm{WO}$ niveau verwacht, is tussen begin 2008 en begin 2009 gedaald van $40 \%$ naar $28 \%$.

Het lijkt er dus op dat de crisis er voor heeft gezorgd dat de verwachte werkgelegenheidsgroei wordt afgevlakt, maar dat dit niet meteen betekent dat de werkgelegenheid over de hele breedte zal gaan afnemen: slechts $6 \%$ van de bedrijven verwacht begin 2009 een daling van de werkgelegenheid voor MBO-ers tegenover geen enkel bedrijf begin 2008. Ook het percentage bedrijven dat een daling in de werkgelegenheid voor $\mathrm{HBO}$-ers verwacht is gestegen van $\mathrm{I} \%$ begin 2008 naar $8 \%$ begin 2009 . Voor de LBOfuncties verwacht begin 2009 wel $37 \%$ van de bedrijven een afname in de werkgelegenheid, maar dit heeft vermoedelijk weinig met de crisis te maken: dit percentage was voor de crisis namelijk nog hoger (42\%).

\section{Figuur 7.1}

Verwachte werkgelegenheidsontwikkeling naar opleidingsniveau in 2009-2010 (\% bedrijven)

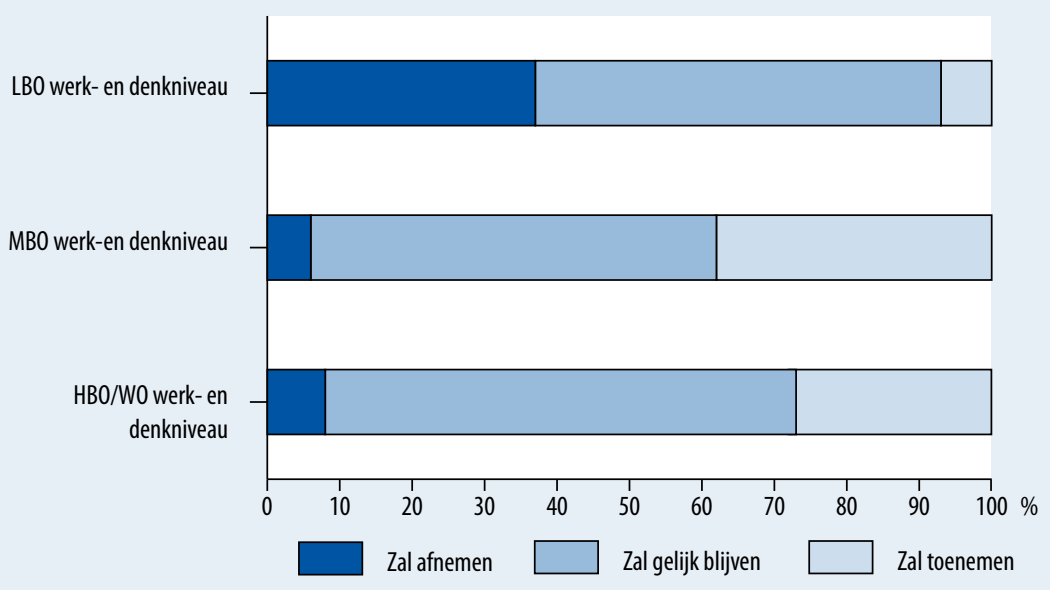

Bron: ROA / Werkgeverspanel Metalektro 2008

De verschuiving in de verwachte ontwikkeling van de werkgelegenheid naar opleidingsniveau is wellicht kleiner dan men zou verwachten als gevolg van de crisis. Een mogelijke verklaring hiervoor is dat lang niet elk bedrijf last heeft van de crisis en ook niet in dezelfde mate. Ook zijn er bedrijven die door de groei van de laatste jaren nu nog volop in het werk zitten en pas over één à anderhalf jaar iets gaan merken van de crisis. Een andere verklaring zou kunnen zijn dat er onder bedrijven heel verschillend gedacht wordt over de duur van de crisis: bedrijven die bijvoorbeeld verwachten dat het ergste leed aan het eind van 2009 geleden is, zullen eerder aangeven voor de periode 2009-20IO een groei of gelijkblijvende werkgelegenheid te verwachten dan een daling dan bedrijven die rekening houden met een langdurige crisis. 
Wanneer in figuur 7.2 wordt gekeken naar de verwachte toe- of afname in aantallen werknemers dan valt op dat de krimp van de werkgelegenheid op LBO niveau vele malen groter is dan de werkgelegenheidskrimp van $\mathrm{MBO}$ en $\mathrm{HBO} / \mathrm{WO}$ functies. De gezamenlijke Metalektrobedrijven rapporteren een verwachte afname in de werkgelegenheid op LBO niveau van maar liefst 2.650 werknemers. Dit is ongeveer een verdubbeling ten opzichte van de verwachte afname begin 2008 (I.360 werknemers). De afname van werkgelegenheid op $\mathrm{MBO}$ niveau betreft 'slechts' I6o werknemers en op HBO/WO niveau gaat het om 240 werknemers. Aan de ene kant lijken deze cijfers enigszins in het niet te vallen bij de grote afname van het aantal LBO functies. Echter, een jaar eerder verwachtten de metalektrobedrijven geen enkele afname van $\mathrm{MBO}$ functies en slechts een afname van Io werknemers op een $\mathrm{HBO} / \mathrm{WO}$ functie.

De metalektrobedrijven verwachten een toename van het aantal werknemers met een MBO niveau met 2.270 personen. Dit aantal is opmerkelijk te noemen aangezien het een groter aantal is dan begin 2008 toen men een toename met I.7IO werknemers verwachtte. Dit aantal wordt des te opmerkelijker als het wordt afgezet tegenover het dalende percentage bedrijven dat zegt een toename in werkgelegenheid op MBOniveau te verwachten. Het lijkt er op dat er zich onder de metalektrobedrijven een aantal fikse groeiers bevinden. De toename van werknemers op $\mathrm{HBO} / \mathrm{WO}$ niveau is met I.020 personen slechts iets lager dan een jaar eerder (I.090).

Figuur 7.2

Verwachte werkgelegenheidsontwikkeling naar opleidingsniveau (aantallen werknemers)

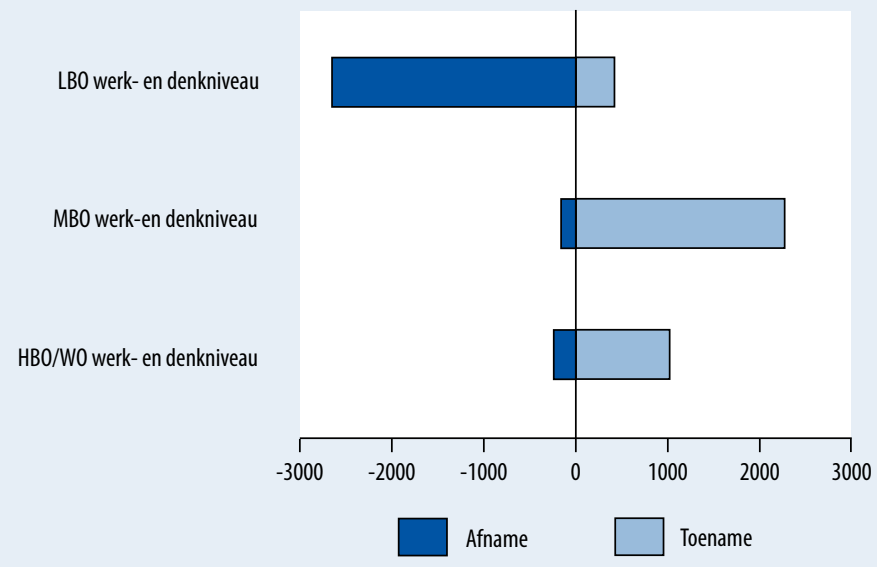

Bron: ROA / Werkgeverspanel Metalektro 2008

De werkgelegenheid voor werknemers in de Metalektro met een $\mathrm{MBO}$ of $\mathrm{HBO} / \mathrm{WO}$ werk- en denkniveau lijkt, vooral in absolute aantallen, nog weinig te lijden te hebben van de crisis. In de hoek van de werknemers met een LBO werk- en denkniveau vallen daarentegen rake klappen. Dit is, naast de reeds ingezette trend, mogelijk het gevolg 
van verdringingseffecten op een iets minder krap wordende arbeidsmarkt. Immers, bij afnemende werkgelegenheid zijn mensen met een $\mathrm{MBO}$ of $\mathrm{HBO} / \mathrm{WO}$ werk- en denkniveau in staat om (tijdelijk) werk te doen waar een LBO werk- en denkniveau voor staat. Op die manier slagen de bedrijven er in de voor hen waardevolle MBO'ers en $\mathrm{HBO} / \mathrm{WO}$ 'ers van het bedrijf te behouden.

\subsection{Werving op de middellange termijn: 2009-2013}

In crisistijd lijkt het op het eerste gezicht weinig zinvol om naar de werving van nieuw personeel te kijken. Echter, uit de figuren 7.I en 7.2 is gebleken dat er, ondanks de crisis, nog behoorlijk wat bedrijven op zoek zijn naar nieuwe medewerkers. Sommige bedrijven anticiperen wellicht al op het einde van de crisis en dan wordt werving van nieuw personeel weer net zo belangrijk als voor de crisis. Bovendien dient men niet te vergeten dat de vergrijzing in de Metalektro gewoon doorgaat en dat er de komende jaren sprake zal zijn van een aanzienlijke vervangingsvraag. Deze vervangingsvraag zal door de crisis voor sommige bedrijven nu misschien lager uitvallen, maar bij een aantrekkende economie moet er dan weer extra worden uitgebreid. Kortom, het is van belang voldoende aandacht te blijven besteden aan werving, ook in tijden van crisis.

Het werven van voldoende personeel, zowel in kwantitatief als in kwalitatief opzicht, is al een aantal jaren geen gemakkelijke opgave. Een groot probleem is en blijft het te lage aantal schoolverlaters van de technische opleidingen (zie figuur 7.3). Medio 2007 vond $64 \%$ van de bedrijven dit het belangrijkste probleem voor de komende jaren en een jaar later deelt $60 \%$ van de bedrijven nog steeds deze mening. Het is niet verwonderlijk dat dit een behoorlijk hardnekkig probleem is. Ten eerste is het beïnvloeden van het keuzeproces van scholieren zodat ze voor een technische opleiding kiezen, een langdurig proces. Vervolgens duurt het nog enkele jaren voordat de metalektrobedrijven kunnen profiteren van het feit dat meer jongeren een technische opleiding kiezen. Het percentage bedrijven dat voor de komende vijf jaar wervingsproblemen verwacht, omdat er zich te weinig sollicitanten melden met de juiste competenties, is in 2008 afgenomen van $54 \%$ naar $42 \%$. Eenzelfde trend is waar te nemen bij bedrijven die te weinig aanbod verwachten van mensen met voldoende werkervaring: 50\% van de bedrijven noemde dit in 2007 het belangrijkste wervingsprobleem voor de komende jaren, in 2008 is dit gedaald naar $36 \%$ van de bedrijven.

Daarentegen treden er nauwelijks verschuivingen op in het percentage bedrijven dat vindt dat zij hun vacatures niet op kunnen vullen omdat zich te weinig mensen melden met interesse in een technisch beroep: $24 \%$ van de bedrijven in 2007 tegenover $27 \%$ in 2008. Ook het percentage bedrijven dat in de toekomst problemen met werven verwacht door de concurrentie met andere bedrijven binnen of buiten de Metalektro, is in 2008 niet veranderd. Het aantal bedrijven dat verwacht te worden geconfronteerd met hoge salariseisen neemt daarentegen wel af: van $31 \%$ in 2007 naar $22 \%$ in 2008 . 
Figuur 7.3

Verwachte problemen bij het vinden van technisch personeel in de komende 5 jaar (\% bedrijven)

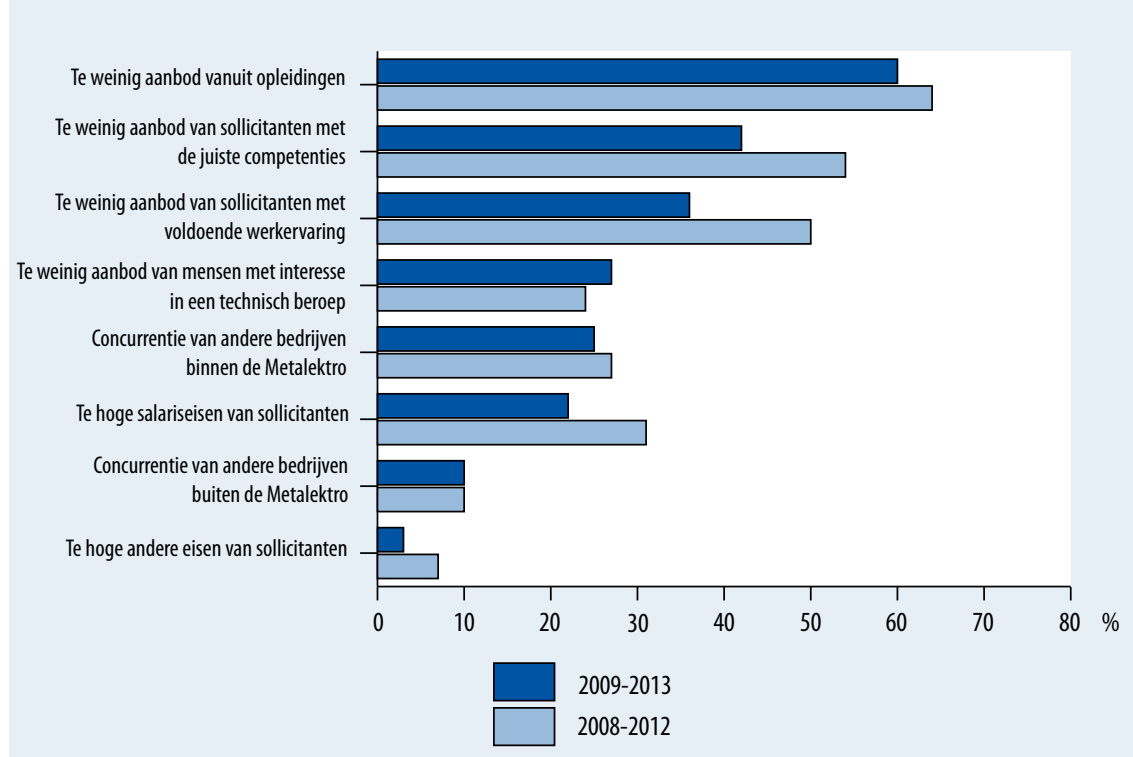

Bron: ROA / Werkgeverspanel Metalektro 2007-2008

\subsection{Veranderingen in technische functies op de middellange termijn: 2009-2013}

De Metalektro is een dynamische branche waarin innovatie erg belangrijk is. Deze innovaties en andere ontwikkelingen kunnen er voor zorgen dat functies in de toekomst zullen veranderen. De vraag is dan welke veranderingen de bedrijven verwachten. Uit figuur 7.4 blijkt dat meer dan de helft van de bedrijven verwacht dat gedragsmatige competenties belangrijker zullen worden. Iets minder dan de helft van de bedrijven verwacht dat technici meer verantwoordelijkheden krijgen en eenzelfde percentage verwacht dat technici meer allround zullen worden. De grotere bedrijven (>IOO medewerkers) verwachten overigens vaker dan de kleinere dat technici de komende jaren meer allround zullen worden. Dit verschil kan mogelijk worden verklaard doordat grotere bedrijven, wellicht ook door de crisis, flexibiliteit van hun personeel belangrijker zijn gaan vinden. Des te meer allround de technici zijn, des te flexibeler zij inzetbaar zijn.

De hiervoor beschreven top 3 van verwachte functieveranderingen is nauwelijks veranderd ten opzichte van 2007. Dit geldt echter niet voor de functieveranderingen die te maken hebben met klantgerichtheid en het specialistischer worden van technische functies. Deze veranderingen worden namelijk in 2008 door relatief minder bedrijven verwacht in de komende 5 jaar dan in 2007. Verwachtte in 2007 nog $48 \%$ van de bedrijven dat klantgerichtheid belangrijker zou worden, in 2008 is dat nog maar $38 \%$ 
van de bedrijven. Het specialistischer worden van technische functies wordt in 2008 door $31 \%$ van de bedrijven verwacht, terwijl dat in 2007 nog bijna de helft van de bedrijven betrof.

Het "meer allround worden" en het "specialistischer worden" lijken elkaar uit te sluiten. De meeste bedrijven verwachten inderdaad slechts één van de twee veranderingen. Echter, I8\% van de metalektrobedrijven verwacht dat technische functies zowel specialistischer als meer allround zullen worden in de komende 5 jaar. Het zijn vooral de grotere bedrijven (>IOO medewerkers) die deze op het oog tegenstrijdige verwachtingen hebben. Een mogelijke verklaring hiervoor is dat in sommige afdelingen van grote bedrijven meer allround functies nuttig zijn, terwijl er in andere afdelingen juist meer vraag is naar specialisten.

\section{Figuur 7.4}

Verwachte veranderingen in functies van het technisch personeel in de komende 5 jaar (\% bedrijven)

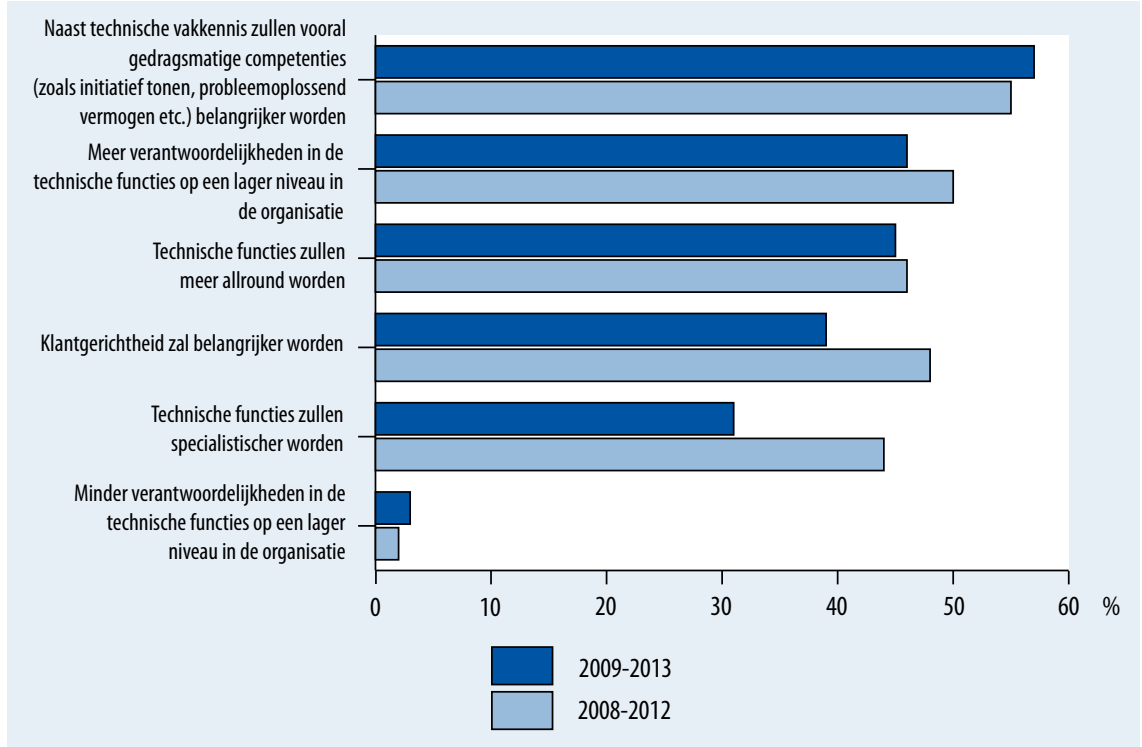

Bron: ROA / Werkgeverspanel Metalektro 2008

Aan de bedrijven is ook gevraagd welke functiewijzigingen zij in 2009 al verwachten. Dit blijkt vooral meer klantgerichtheid (44\%) en meer gebruik van gedragsmatige competenties $(43 \%)$ te zijn. De overige veranderingen worden gemiddeld door slechts I op de 5 bedrijven genoemd. Wanneer deze percentages worden vergeleken met die in figuur 7.4, dan is het duidelijk dat de meeste veranderingen in technische functies geleidelijk plaatsvinden. Dit biedt bedrijven de tijd om het personeel voor te bereiden op deze veranderingen in hun functie, bijvoorbeeld door scholing. Het vergroten van de klantgerichtheid en de gedragsmatige competenties bij de technici dient echter bij een groot 
deel van de bedrijven voorrang te krijgen omdat deze op kortere termijn nodig zijn. Ook gezien de teruglopende vraag waar een deel van de bedrijven mee te kampen heeft, lijkt een focus op het trainen van de klantgerichtheid van technici een goede zaak.

\subsection{HRM beleid op de middellange termijn: 2009-2013}

In het toekomstige HRM beleid is veel aandacht voor aspecten die betrekking hebben op loopbaanmanagement en sociale innovatie (zie figuur 7.5). Dit is niet verwonderlijk gezien de grote voordelen die dat voor bedrijven biedt (zie hoofdstuk 4 en 5 ). Voor bijna $40 \%$ van de bedrijven is het loopbaanmanagement de komende jaren een speerpunt van hun HRM beleid. Het belangrijkste aspect van dit beleid is voor $80 \%$ van de metalektrobedrijven het vergroten van de inzetbaarheid van het personeel. Een grotere inzetbaarheid van het personeel gaat meestal niet zonder scholing, dus zet bijna de helft van de bedrijven zich de komende 5 jaar in om het personeel aan cursussen te laten deelnemen.

Cursussen die voldoende rendement opleveren vragen echter wel de nodige afstemming tussen bedrijven en onderwijsinstellingen. Een deel van de bedrijven noemt immers de kosten, de benodigde tijd en de niet passende inhoud van cursussen als belemmeringen waardoor hun personeel minder aan cursussen deelneemt dan wenselijk is (zie figuur 4.7). Een meer intensieve samenwerking tussen bedrijven en onderwijsinstellingen kan (een deel van) deze belemmeringen wegnemen. $4 \mathrm{I} \%$ van de bedrijven wil de komende 5 jaar intensiever gaan samenwerken met de onderwijsaanbieders.

Eén van de doelen van sociale innovatie is het ontplooien van medewerkers zodat zij optimaal kunnen presteren. Een medewerker die verzuimt, presteert echter niet optimaal. Het is dus van belang om het ziekteverzuim van personeel zoveel mogelijk terug te dringen. Ook de overheid probeert via wetgeving bedrijven te stimuleren het verzuim onder het personeel te verminderen (zie hoofdstuk 6). $56 \%$ van de bedrijven heeft het verminderen van het verzuim tot een speerpunt van het komende HRM beleid gemaakt. Verzuim van medewerkers kan vele oorzaken hebben. Zo kunnen problemen in de privésfeer verzuim bevorderen. Maar het kan ook zijn dat het niveau, de zwaarte of de inhoud van het werk niet meer of nog niet past bij de werknemer. De hieruit volgende over- of onderbelasting van medewerkers kan verzuimverhogend werken. Dit betekent dat bedrijven die zich in hun toekomstig HRM beleid richten op afstemming privé-werk (24\%), leeftijdsbewust personeelsbeleid (32\%), beleid voor $45+$ ers ( $18 \%)$ en flexibele werktijden (23\%) tegelijkertijd ook werken aan het verminderen van verzuim. Ditzelfde geldt voor de al eerder besproken loopbaanaspecten: iemand die zijn competenties ontwikkelt zodat deze blijven passen bij het werk dat men doet, zal waarschijnlijk minder verzuimen dan iemand die een competentietekort of overschot heeft. Bij competentietekorten dreigt langdurig verzuim door overbelasting (burn out), maar een werknemer van wie de competenties onvoldoende benut worden, kan zich 'ziek vervelen' (bore out). 
Sociale innovatie werkt ook via het verschuiven van verantwoordelijkheden aan verbeterde bedrijfsprestaties. Uit figuur 7.4 is al gebleken dat bijna de helft van de bedrijven verwacht dat technici lager in de organisatie meer verantwoordelijkheden zullen dragen. Technici zullen dit waarschijnlijk succesvoller kunnen doen als zij daarin begeleid worden en de arbeidsverhoudingen hierop worden aangepast. 39\% van de bedrijven doet dit door in de komende 5 jaar coachend leiderschap te bevorderen. Ook wil een kwart van de bedrijven personeel meer bij het beleid van de organisatie betrekken. Eenzelfde percentage werkt aan passende modernere arbeidsverhoudingen.

Figuur 7.5

Speerpunten in het personeelsbeleid voor de komende 5 jaar (\% bedrijven)

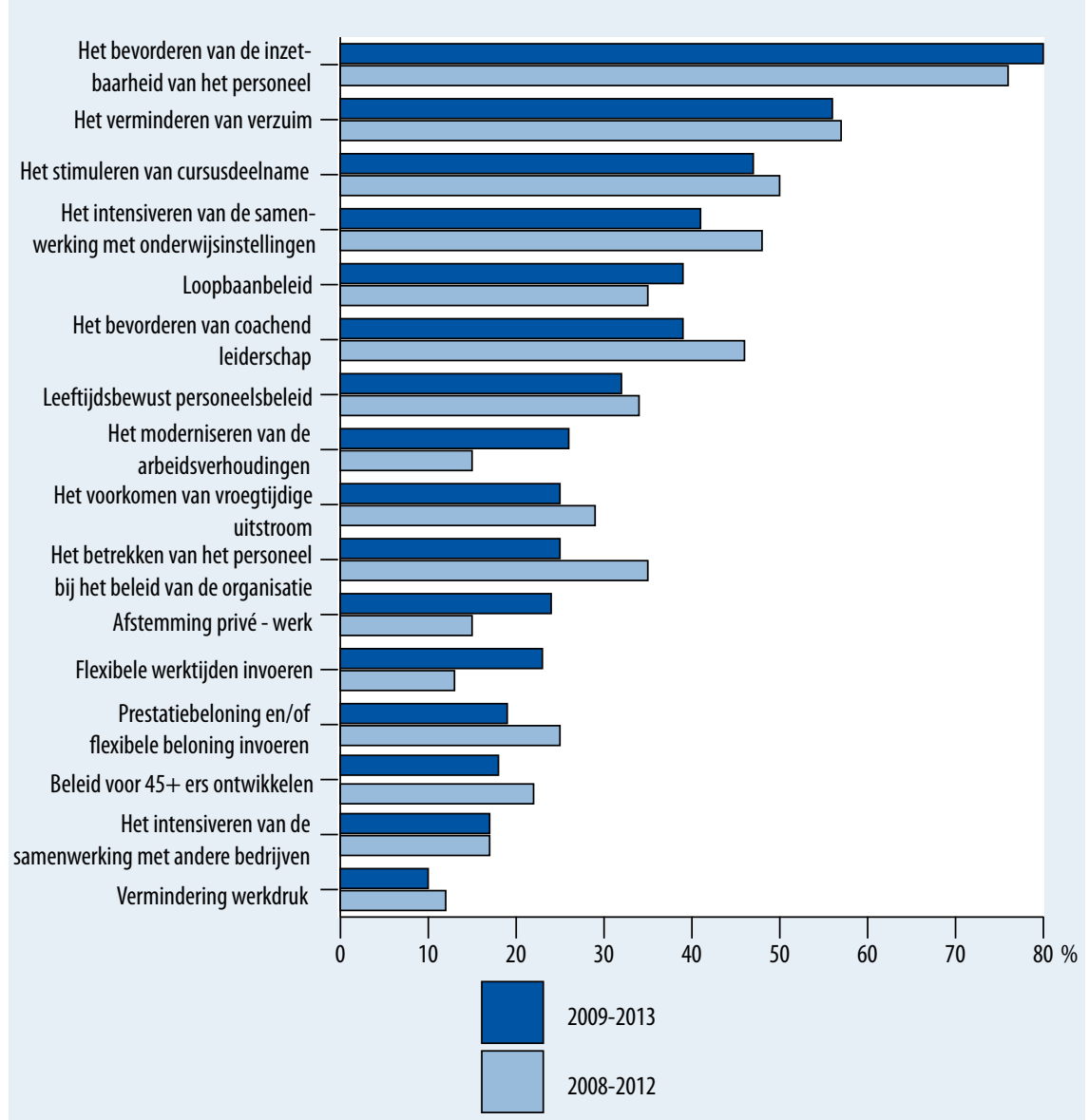

Bron: ROA / Werkgeverspanel Metalektro 2007-2008

Hoe denken bedrijven het toekomstige HRM beleid handen en voeten te geven, welke instrumenten gaan zij daarvoor inzetten? In figuur 7.6 is te zien dat de nieuw te 
gebruiken instrumenten gericht zijn op de competentie-ontwikkeling van het personeel: een derde van de bedrijven is van plan de competentie- of vaardighedenmatrix te gebruiken en eenzelfde percentage een competentiemanagementsysteem. Ook wil een derde van de bedrijven POP's gaan opstellen of een EVC. $35 \%$ van de bedrijven wil de loopbanen van hun personeel meer planmatig gaan aanpakken.

\section{Figuur 7.6}

HRM instrumenten die zullen worden gebruikt voor toekomstige speerpunten van het HRM beleid (\% bedrijven)

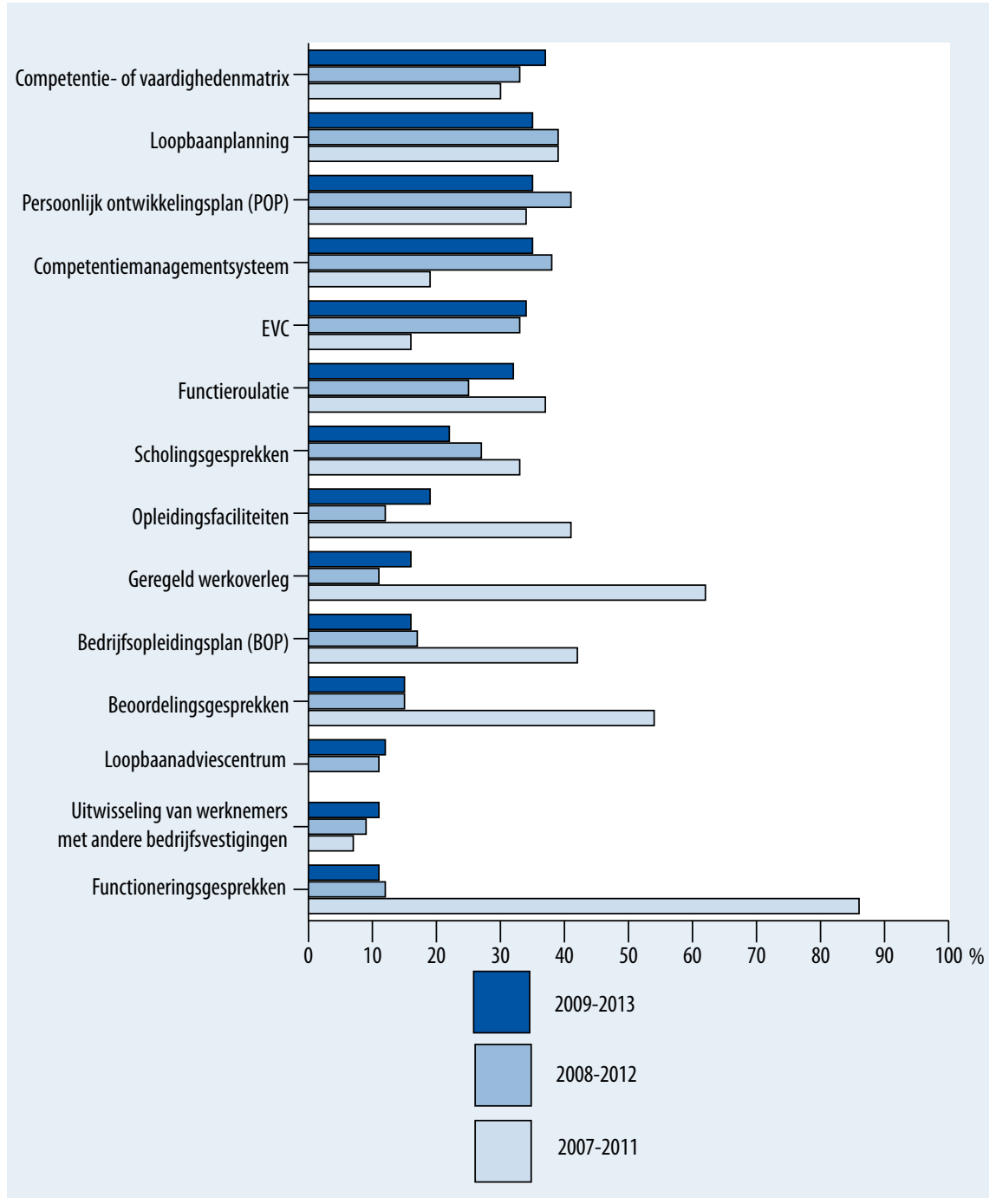

Bron: ROA / Werkgeverspanel Metalektro 2006-2008 
Het verloop van de nieuw in te zetten instrumenten over de afgelopen 3 jaar laat zien dat bepaalde instrumenten waarschijnlijk al geïmplementeerd zijn. Zo waren functioneringsgesprekken in 2006 voor $86 \%$ van de bedrijven een speerpunt voor hun HRM beleid in de periode $2007-201$. Inmiddels is dit percentage gedaald naar II\% van de bedrijven die dit instrument als een speerpunt zien van de periode 2009-2013. Ruim $80 \%$ van de bedrijven makt inderdaad reeds gebruik van functioneringsgesprekken (zie figuur 4.I). Eenzelfde overgang van een toekomstig speerpunt van het HRM beleid naar het daadwerkelijk gebruik is te zien bij de opleidingsfaciliteiten, geregeld werkoverleg, BOP en beoordelingsgesprekken. Bij elk van deze instrumenten zijn de percentages bedrijven die deze instrumenten willen gebruiken voor het toekomstig HRM beleid tussen 2006 en 2008 gedaald (zie figuur 7.6). In dezelfde periode zijn de percentages bedrijven die deze instrumenten in hun HRM repertoire hebben opgenomen gestegen (zie hoofdstuk 4). 


\section{Agenda voor de toekomst}

In dit hoofdstuk passeren de belangrijkste ontwikkelingen in de metalektrosector de revue en kijken we naar wat deze ontwikkelingen betekenen voor het beleid van de bedrijven. In paragraaf 8.I wordt achtereenvolgens ingegaan op de huidige crisis, het ontwikkelen van een lange-termijn strategie ten aanzien van de personeelsbehoefte, de voortschrijdende upgrading van het gevraagde competentieniveau en de vraag naar "POFI+" competenties, het opleidingsbeleid, het werven en zelf opleiden van nieuw personeel, loopbaanmanagementbeleid en het levensfasebewuste personeelsbeleid van de bedrijven. In paragraaf 8.2 wordt een vernieuwde Agenda voor de Toekomst gepresenteerd. Deze agenda biedt een zevental handreikingen welke er op gericht zijn de effectiviteit van het arbeidsmarkten personeelsontwikkelingsbeleid van de metalektrobedrijven de komende jaren verder te vergroten.

\subsection{Ontwikkelingen en trends}

\section{De crisis}

De Metalektro heeft sinds het najaar van 2008 flink te kampen met de effecten van de huidige crisis: een groot aantal bedrijven wordt geconfronteerd met een aanzienlijke vraaguitval en een krimpende werkgelegenheid. Het is wat dat betreft opmerkelijk dat ruim 50\% van de metalektrobedrijven voor de komende jaren toch een gelijkblijvende werkgelegenheid verwacht. Wanneer er sprake is van werkgelegenheidskrimp dan doet deze zich voornamelijk voor bij functies op LBO niveau. Hoewel de omzetdaling voor een aantal bedrijven ongekend groot is, blijkt ook dat de metalektrobedrijven zeer veel baat hebben bij de 'flexibele schillen' die zij de afgelopen jaren hebben gecreëerd. Deze flexibele schillen vormen een goede buffer om de sterke terugval in de afzet voor een belangrijk deel op te vangen. Bedrijven slagen er in om hun kernpersoneel voor het bedrijf te behouden door het afstoten van uitzendkrachten en tijdelijk personeel. Ook trekken ze werk dat ze voorheen hadden afgestoten naar andere bedrijven weer naar zich toe. Als ze mensen laten afvloeien dan zijn dit vooral de laagopgeleiden, waarvan de taken tijdelijk door de vakkrachten worden overgenomen. Last but not least gebruiken veel bedrijven de leegloopuren als gevolg van de afname van het werk, voor het bijscholen van het personeel dat men in vaste dienst heeft. 
Ook blijkt dat er ondanks de crisis moeilijk vervulbare vacatures open blijven staan voor gespecialiseerd technisch personeel. Bij nogal wat bedrijven blijft de wervingsproblematiek dus op de agenda staan.

\section{Lange-termijn strategie ten aanzien van de personeelsbehoefte}

Veel metalektrobedrijven geven aan dat het wenselijk zou zijn om een goede langetermijn strategie te hebben voor het invullen van hun personeelsbehoefte. De meeste bedrijven slagen er om verschillende redenen echter niet in om dit te realiseren. Sommige bedrijven geven aan dat hun bedrijf te klein is om een lange-termijn strategie rendabel te maken. Andere bedrijven zeggen dat hun personeelsverloop moeilijk te voorspellen is, of dat hun afzet hiervoor teveel fluctueert. De huidige crisis bevestigt dit nog eens.

De bedrijven die wel een lange-termijn strategie met betrekking tot de invulling van hun personeelsbehoefte hebben ontwikkeld, proberen allereerst een goed beeld te krijgen van het verwachte personeelsverloop in de komende jaren. Zeker op dit moment is dit van groot belang, omdat het ook een antwoord geeft op de vraag hoe kostbaar het is om nu mensen af te laten vloeien vanwege de sterk gedaalde omzet. Wanneer bedrijven een goed beeld hebben van hun vervangingsbehoefte in de komende jaren, dan krijgt men ook inzicht in de vraag hoe aantrekkelijk het is om de flexibele schil in te krimpen. De toekomstige vervangingsbehoefte kan leiden tot de conclusie dat het verstandiger is om over te gaan tot deeltijdontslag in plaats van de momenteel overtollige vaste medewerkers te ontslaan. Daarmee kan men het op dit moment overtollige personeel immers aan zich blijven binden en het dienstverband weer in een voltijdse baan omzetten om de banen in te vullen die er de komende jaren vrijkomen vanwege de uitstroom van oudere medewerkers die met pensioen gaan.

Andere belangrijke elementen van een adequate lange-termijn strategie zijn het opleiden van het eigen personeel voor de te verwachten vacatures en het versterken van de samenwerking met scholen om de toekomstige instroom van schoolverlaters te vergroten. Ook hiervoor is het belangrijk om goede informatie te hebben over de verwachte vervangingsbehoefte.

\section{Voortschrijdende upgrading en vraag naar POFI+ competenties}

De dynamiek van de Metalektro zal de komende jaren onveranderd groot blijven. Product- en procesinnovaties en de daaraan gerelateerde organisatorische veranderingen leiden in veel bedrijven tot een upgrading van de vereiste competenties. De huidige crisis blijkt de upgrading van het personeelsbestand te versterken. Bedrijven blijken de gedaalde afzet op te vangen door met name werknemers die niet op MBO niveau kunnen functioneren af te laten vloeien. Door hun taken gedurende de crisis (tijdelijk) te laten overnemen door MBO'ers kan men de vakkrachten die men in huis heeft voor het bedrijf behouden. 
De huidige crisis lijkt ook de behoefte aan breed inzetbaar personeel te versterken. Dit uit zich ook in de toenemende vraag naar allround technici die verantwoordelijkheid kunnen dragen voor de invulling van hun werk. Het zijn echter vooral de ontwikkelingen op de afzetmarkt die vereisen dat het technisch personeel naast de noodzakelijke vaktechnische competenties ook beschikt over de gedragsmatige competenties die in de vorige edities van de Arbeidsmarktmonitor Metalektro zijn benadrukt in de $P O F I+$ agenda.
a. Probleemoplossend vermogen.
b. Omgaan met veranderingen.
c. Omgaan met klanten.
d. Flexibiliteit.
e. Initiatief.

\section{Opleidingsbeleid}

De vereiste upgrading van het personeel en de toenemende vraag naar technici die beschikken over de genoemde POFI+ competenties vergen aanzienlijke investeringen in trainingen en opleidingen voor het personeel. Het is dan ook niet verwonderlijk dat de opleidingsuitgaven van de metalektrobedrijven, ondanks de druk van de crisis, in procenten van de loonsom in 2008 weer verder zijn gestegen. Bij de meeste bedrijven ligt het accent in het scholingsbeleid nog steeds op de vaktechnische cursussen. Dit illustreert het grote belang dat veel bedrijven hechten aan het up-todate houden van de competenties van hun technisch personeel. Veel bedrijven geven echter aan dat ze de komende jaren de trainingen meer willen richten op het verbeteren van de communicatieve vaardigheden en het probleemoplossend vermogen van hun personeel, terwijl een op de vijf bedrijven aangeeft dat ze meer aandacht willen gaan schenken aan cursussen die gericht zijn op het omgaan met veranderingen. Dit illustreert dat de metalektrobedrijven er nog steeds op gericht zijn om actiever invulling te gaan geven aan de POFI+ agenda.

Een positieve ontwikkeling in dit verband is ook dat er een duidelijke toename is van het aantal metalektrobedrijven waarvoor het bevorderen van coachend leiderschap een speerpunt is in het personeelsbeleid voor de komende jaren. Coachend leiderschap biedt ook goede mogelijkheden voor medewerkers om de POFI+ competenties "on-the-job" te verwerven.

\section{Werven en zelf opleiden van nieuw personeel}

Ondanks de scherpe daling van het aantal vacatures in de tweede helft van 2008 zijn er nog steeds moeilijk vervulbare vacatures voor gespecialiseerde functies. In de regio's Noord/Oost en Zuid Nederland stond eind 2008 zelfs meer dan twee derde van de (resterende) vacatures al meer dan een half jaar open. Door de vergrijzing van het personeel en het te geringe aanbod van schoolverlaters zal de krapte op de arbeidsmarkt weer snel toenemen als de economie weer aantrekt. 
De meeste bedrijven maken bij hun werving gebruik van uitzendbureaus of andere commerciële werving- en selectiebureaus. Deze wervingskanalen zijn ook zeer geschikt om bij het aantrekken van de vraag weer een flexibele schil van uitzendkrachten en mensen met tijdelijke contracten te creëren. In 2008 is er ook een verdere toename van het aantal bedrijven dat scholieren actiever benadert om bij hen te gaan werken. Het op peil houden van de instroom van nieuw personeel vereist echter ook dat bedrijven meer gaan investeren in hun relaties met het onderwijsveld.

Het overgrote deel van de bedrijven neemt nieuw personeel aan dat nog niet de vereiste competenties heeft, om ze vervolgens zelf op te leiden. In dat verband is het opmerkelijk dat de werkgevers in de Metalektro die $\mathrm{MBO}$ en $\mathrm{HBO}$ schoolverlaters aantrekken, meer aansluitingsproblemen ervaren dan de schoolverlaters zelf. Dit wijst er op dat werkgevers de aansluitingsproblemen die zij ervaren onvoldoende communiceren naar de schoolverlaters zelf. Dit zou verbeterd kunnen worden door met Persoonlijke Opleidingsplannen (POP's) te gaan werken waarin de plannen kunnen worden vastgelegd om het vereiste competentieniveau te bereiken. In 2008 maakte overigens al $4 \mathrm{I} \%$ van de metalektrobedrijven gebruik van POP's.

\section{Loopbaanmanagment}

Een goed loopbaanbeleid vereist goed loopbaanmanagement. Hierdoor kan een werknemer doorgroeien qua competenties en verantwoordelijkheden. Ook biedt het de mogelijkheid om jonge medewerkers die kampen met aansluitingsproblemen tussen de door hen gevolgde opleiding en de eisen die hun functie stelt een goed ontwikkelingspad te bieden. Vanzelfsprekend is een goed loopbaanmanagement ook nauw verbonden met het opleidingsbeleid van het bedrijf. In dat geval is daadwerkelijk sprake van een personeelsontwikkelingsbeleid.

Goed loopbaanmanagement start met het in kaart brengen van het competentieniveau van de medewerkers. De meeste metalektrobedrijven volstaan op dit punt met functioneringsgesprekken. Ruim een derde van de bedrijven gaat meer systematisch te werk door het opstellen van een competentie- of vaardighedenmatrix, terwijl nog maar Iı\% van de bedrijven gebruik maakt van EVC. Zoals gezegd, maakt een veel grotere groep bedrijven al wel gebruik van POP's waarbinnen scholingsafspraken met individuele medewerkers worden vastgelegd. Een derde van de bedrijven geeft echter wel aan in de toekomst gebruik te gaan maken van EVC.

De interne mobiliteitsperspectieven die een bedrijf biedt bevorderen ook een optimale ontwikkeling van de competenties en werkervaring van het personeel. Ondanks de crisis is er in $60 \%$ van de bedrijven nog sprake van doorstroom van medewerkers naar andere functies. Meestal liggen deze functies op een hoger niveau. Daarentegen zijn bedrijven wat terughoudender geworden in het gebruik van functieroulatie. Veel bedrijven zijn echter van plan om in de toekomst meer aandacht te besteden aan de loopbaanplanning van hun uitvoerend technisch personeel. Dit zou een belangrijke 
bijdrage kunnen leveren aan het vergroten van de motivatie van het personeel, waardoor ongewenst personeelsverloop wordt voorkomen. Het coachend leiderschap dat bijna $40 \%$ van de bedrijven de komende jaren wil bevorderen kan dit proces van "boeien en binden" nog versterken.

\section{Levensfasebewust personeelsbeleid stagneert}

Het aantal bedrijven dat problemen verwacht bij het vervangen van het technisch personeel dat de komende jaren met pensioen gaat, laat de afgelopen jaren een continu stijgende lijn zien. Dit maakt het voor de Metalektro steeds belangrijker om de vroegtijdige pensioenuitstroom van het oudere personeel zoveel mogelijk te beperken. Wat dat betreft is het opmerkelijk dat slechts zo'n $30 \%$ van de bedrijven oudere werknemers stimuleert om langer door te werken. Aan de andere kant zien we dat $20 \%$ van de bedrijven zelfs mensen die al met pensioen zijn tijdelijk weer terughaalt.

De vergrijzing van het personeelsbestand van veel metalektrobedrijven maakt het belangrijk om voldoende aandacht te hebben voor het op peil houden van de inzetbaarheid van oudere medewerkers. Het aantal bedrijven dat aangeeft dat een levensfasebewust personeelsbeleid de komende jaren een speerpunt vormt in het personeelsbeleid, is in 2008 echter licht afgenomen. Meer dan tweederde van de bedrijven lijkt hier onvoldoende aandacht voor te hebben. Dit wordt versterkt door de huidige crisis. Zo is er een sterke terugval in het aantal bedrijven dat probeert de kennis en vaardigheden van hun oudere medewerkers op een optimale wijze te kunnen benutten en de werkzaamheden beter probeert af te stemmen op de wensen van de oudere medewerkers. Dit wijst er sterk op dat nogal wat bedrijven momenteel minder gericht zijn op het langer vasthouden van hun oudere medewerkers. Wanneer oudere medewerkers hierdoor langzamerhand minder goed inzetbaar worden kan dat op termijn zijn gevolgen hebben. Dit zal vooral het geval zijn wanneer de arbeidsmarkt weer aantrekt.

\section{Sociale innovatie}

Maar liefst $95 \%$ van de metalektrobedrijven geeft aan dat ze in 2008 minimaal één sociale innovatie hebben doorgevoerd of dat in de komende jaren zullen doen. Bij veel bedrijven ligt de nadruk daarbij vooral op het horizontaal organiseren van het werk, zoals het projectmatig gaan werken, het creëren van multifunctionele teams en taakintegratie over afdelingen. Daarnaast is de sociale innovatie in veel bedrijven gericht op het variabel inzetten van het personeel, om daarmee schommelingen in de bedrijvigheid en ziekteverzuim op te kunnen vangen. Voor een aantal bedrijven heeft de huidige crisis op dit punt wel een schaduwzijde. Zo geeft een kwart van de bedrijven aan dat ze momenteel onvoldoende middelen hebben om de sociale innovaties die ze willen doorvoeren daadwerkelijk te realiseren. Ook het feit dat het personeel moeilijk kan omgaan met veranderingen belemmert bij nogal wat bedrijven de sociale innovatie. 
Sociale innovatie heeft bij de meeste bedrijven als doel het verhogen van de arbeidsproductiviteit en het verbeteren van de kwaliteit van de producten. Vooral zelfsturende teams en taakintegratie over afdelingen leveren al op korte termijn succes op. Veel bedrijven beseffen ook dat ze op deze manier kwalitatief hoogwaardige werkgelegenheid kunnen bieden die de aantrekkingskracht die het bedrijf heeft op de arbeidsmarkt zal vergroten. De meeste bedrijven hebben ook aandacht voor het verbeteren van de afstemming van werk en privé. Wel biedt men het niet-technisch personeel op dit punt meer mogelijkheden aan dan het technisch personeel. Dit geldt ook voor de mogelijkheden om in deeltijd te werken. Een toenemend aantal bedrijven geeft echter aan dat het verbeteren van de afstemming van werk en privé een speerpunt is van hun HRM beleid voor de komende jaren.

Sociale innovatie richt zich daarnaast ook op de externe organisatie: de samenwerking met andere bedrijven en kennisinstellingen. Deze is veelal gericht op het uitbesteden van bepaalde activiteiten. De uitbesteding van werkzaamheden naar het buitenland is echter in 2008 onder druk van de crisis afgenomen. Daarentegen zijn veel bedrijven van plan de komende jaren intensiever te gaan samenwerken met onderwijsinstellingen.

\section{Verspreiding good practices en HR tools}

Kleinere en middelgrote bedrijven blijken vaak onvoldoende mogelijkheden te hebben om hun personeelsontwikkelings- en arbeidsmarktbeleid op eigen kracht verder te ontwikkelen. Regionale samenwerking met andere bedrijven kan hier een oplossing bieden. Dit is zeker het geval wanneer kleinere bedrijven onvoldoende informatie hebben over de mogelijkheden tot en de voor- en nadelen van verschillende sociale innovaties. Daarbij gaat het ook om de overdracht van "good practices". Het gaat hierbij vooral om het identificeren van initiatieven op het vlak van arbeidsmarkt- en personeelsbeleid die bij andere bedrijven effectief blijken te zijn.

De overdracht van good practices kan er ook toe bijdragen dat niet ieder bedrijf zelf op zoek hoeft te gaan naar de wijze waarop bepaalde vormen van sociale innovatie ontwikkeld en geïmplementeerd kunnen worden. Daarbij is het van groot belang dat de inzichten die verkregen zijn uit de good practices vertaald worden in een aantal toegankelijke, gemakkelijk hanteerbare, en direct implementeerbare tools. Met behulp van deze concrete HR-tools kunnen veel bedrijven in de Metalektro de effectiviteit van hun arbeidsmarkt- en personeelsontwikkelingsbeleid vergroten.

\subsection{Agenda voor de Toekomst}

Wat betekenen de ontwikkelingen in de Metalektro voor het beleid dat de bedrijven de komende jaren moeten gaan voeren? We vatten de belangrijkste punten samen in de Agenda voor de Toekomst. Vanzelfsprekend bouwt deze Agenda voor de Toekomst voort 
op de in de vorige edities van de Arbeidsmarktmonitor geformuleerde aandachtspunten. Daarbij staat nu echter wel de vraag centraal hoe metalektrobedrijven moeten inspelen op de implicaties van de huidige crisis.

\section{Lange-termijn strategie personeelsbehoefte}

Bedrijven zullen moeten proberen om hun HR beleid in te bedden in een langetermijn strategie voor het invullen van hun personeelsbehoefte en de timing van het weer opbouwen van de flexibele schillen die men in de huidige crisis heeft afgestoten. Startpunt van deze strategie is het zo goed mogelijk in kaart brengen van de verwachte personeelsbehoefte in de komende jaren. Dit kan ook belangrijke leidraad bieden voor het wervings- en ontslagbeleid van bedrijven die momenteel kampen met een sterke daling van hun omzet. Daarbij is het vooral ook belangrijk om een goed beeld te krijgen van de in de komende jaren te verwachten vervangingsvraag vanwege de uitstroom van oudere medewerkers die met pensioen gaan.

In aanvulling daarop zal vanuit deze lange-termijn strategie moeten worden bezien in hoeverre de hieronder genoemde actiepunten binnen het bedrijf meer of minder accent moeten krijgen.

\section{Opleidings-en ontwikelingsbeleid}

Naast het investeren in vaktechnische vaardigheden en de inspanningen om de upgradingsdoelstellingen te realiseren, moet door de metalektrobedrijven ook worden ingespeeld op de toenemende behoefte aan allround vakmensen die verantwoordelijkheid kunnen dragen voor de invulling van hun eigen werkzaamheden. Dit vereist een toenemende aandacht voor de vijf essentiële gedragsmatige competenties, die we kunnen aanduiden als de POFI+ agenda:

- Probleemoplossend vermogen.

- Omgaan met veranderingen.

- Omgaan met klanten.

- Flexibiliteit.

- Initiatief.

Metalektrobedrijven zullen daarom in hun opleidings- en ontwikkelingsbeleid veel aandacht moeten blijven schenken aan het versterken van de POFI+ competenties van hun technisch personeel. Het zou wenselijk zijn om de bijscholing van het personeel waarvoor men momenteel onvoldoende werk heeft hier voor een deel ook op te richten. Ook dient er meer aandacht te komen voor het versterken van het informele leren op de werkvloer. 


\section{Wervingsbeleid}

Wanneer de economie weer gaat aantrekken zullen de metalektrobedrijven vanwege de toenemende uitstroom van oudere medewerkers die met pensioen gaan, weer snel geconfronteerd worden met een krappe arbeidsmarkt voor technisch opgeleiden. Dit vereist dat bedrijven veel aandacht blijven houden voor het vergroten van hun wervingskracht op de arbeidsmarkt. Dit beleid moet zich richten op:

- Het bieden van een aantrekkelijk loopbaanperspectief aan nieuwe medewerkers.

- Het verder ontwikkelen van innovatieve manieren van samenwerking met het onderwijsveld.

- Het verbeteren van het imago van de metalektrosector.

- Het zelf opleiden van nieuwe medewerkers

\section{Loopbaanmanagement}

Het HRM moet zich meer gaan richten op het stimuleren van verschillende vormen van interne mobiliteit, niet alleen vanwege de innovatiedynamiek en de behoefte aan flexibiliteit, maar ook om het personeel aantrekkelijke loopbanen te kunnen bieden en ongewenst verloop te voorkomen. Door het creëren van functies waarin werknemers verschillende aan elkaar gerelateerde taken vanuit een eigen verantwoordelijkheid uitvoeren ontstaat hoogwaardige werkgelegenheid die medewerkers boeit en bindt en de aantrekkingskracht van de sector op de arbeidsmarkt vergroot. Het stimuleren van coachend leiderschap kan daarbij de ontwikkelings- en loopbaanperspectieven van het personeel versterken.

\section{Levensfasebewust personeelsbeleid}

De verdere ontwikkeling van levensfasebewust personeelsbeleid dat gericht is op vier cruciale elementen:

- Een pro-actief levensfasebewust personeelsbeleid voor alle werknemers.

- Investeren in de competentieontwikkeling van het oudere personeel door scholing, functieroulatie en informeel leren.

- Zorgen dat oudere werknemers zo lang mogelijk productief aan de slag kunnen blijven door middel van een gericht Active Aging beleid.

- Het stimuleren van mobiliteit in de laatste loopbaanfase en het ontwikkelen van flexibele uittredemogelijkheden die aansluiten bij de behoeften van het bedrijf en de medewerkers. 


\section{Sociale innovatie}

Veel van de bovenstaande agendapunten vereisen dat bedrijven sociale innovatie weten te realiseren gericht op het aantrekken en ontwikkelen van optimaal inzetbaar personeel. Dit vereist het vergroten van het innovatievermogen van het HRM beleid binnen de grenzen van de mogelijkheden die het bedrijf hiervoor heeft. Om dit te kunnen realiseren moeten bedrijven zich niet richten op het simpelweg kopieren van populaire 'best practices', maar op soortgelijke wijze als ze dat doen bij technologische innovaties, meer aandacht geven aan de Research \& Development $(\mathrm{R} \& \mathrm{D})$ met betrekking tot sociale innovatie. Ook op dit punt is het verbeteren van de samenwerking met kennisinstellingen gewenst.

\section{Verspreiding van good practices en HR tools}

Kleinere en middelgrote bedrijven moeten de effectiviteit van het arbeidsmarkten personeelsontwikkelingsbeleid vergroten door samenwerking en kennisdeling op regionaal niveau en het verspreiden van good practices en bruikbare HR tools. $\mathrm{Om}$ deze vernieuwingsprocessen te ondersteunen, zouden de kleinere bedrijven meer samen op moeten trekken. Zo kunnen ze bijvoorbeeld innovatievouchers inzetten om de samenwerking met kennisinstellingen gericht op de implementatie van sociale innovaties te bekostigen. 
